CATHERINE GÉRIKAS RIBEIRO

\title{
Pico- and nanoplankton abundance and biomass in the Southwest Atlantic Ocean off Brazil
}

Tese apresentada ao Instituto Oceanográfico da Universidade de São Paulo, como parte dos requisitos para obtenção do título de Doutora em Ciências, área de Oceanografia Biológica

Orientador: Prof. Dr. Frederico Pereira Brandini

São Paulo

2016 


\section{UNIVERSIDADE DE SÃO PAULO \\ INSTITUTO OCEANOGRÁFICO}

\section{Pico- and nanoplankton abundance and biomass in the Southwest Atlantic Ocean off Brazil}

\section{Catherine Gérikas Ribeiro}

Tese apresentada ao Instituto Oceanográfico da Universidade de São Paulo, como parte dos requisitos para obtenção do título de Doutora em Ciências, área de Oceanografia Biológica

Julgada em

Conceito

$\operatorname{Prof}(\mathrm{a}) . \operatorname{Dr}(\mathrm{a})$.

Conceito

$\operatorname{Prof}(\mathrm{a}) . \operatorname{Dr}(\mathrm{a})$.

Conceito

$\operatorname{Prof}(\mathrm{a}) . \operatorname{Dr}(\mathrm{a})$.

Conceito

$\operatorname{Prof}(\mathrm{a}) . \operatorname{Dr}(\mathrm{a})$.

Conceito

Prof(a). Dr(a). 


\section{SUMMARY}

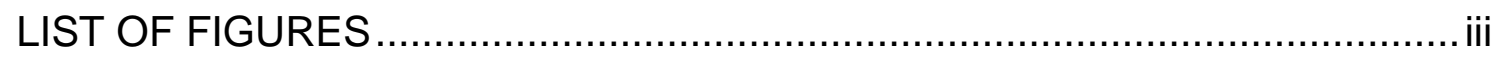

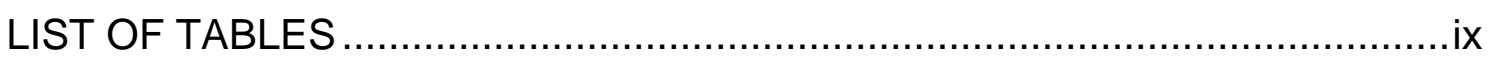

ACKNOWLEDGMENTS / AGRADECIMENTOS ....................................... $\mathrm{x}$

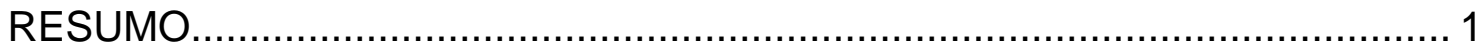

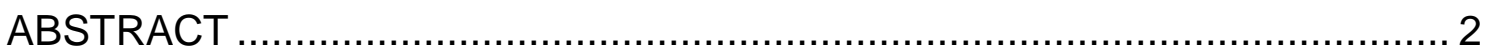

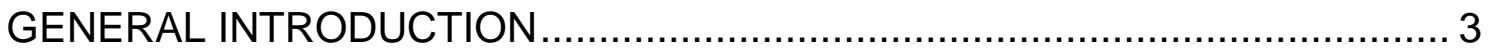

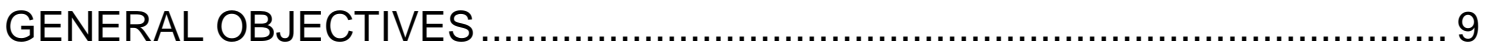

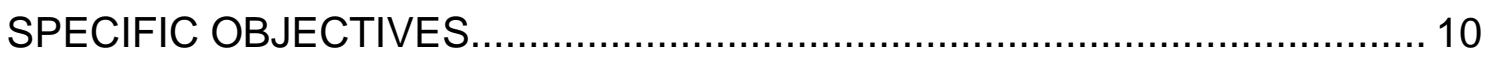

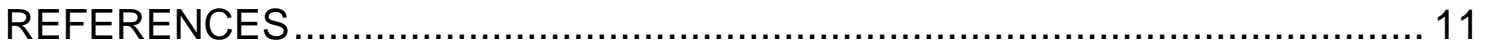

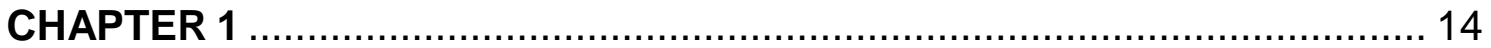

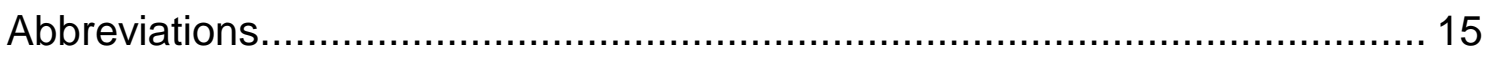

RESUMO

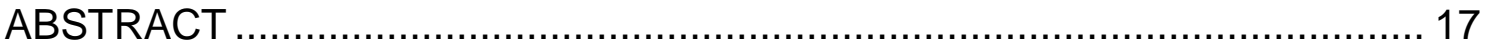

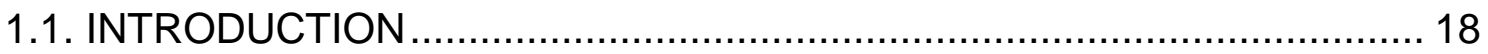

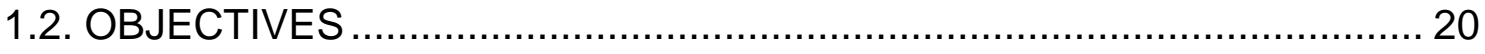

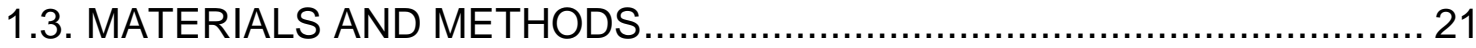

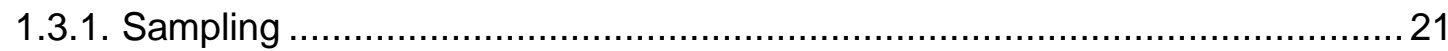

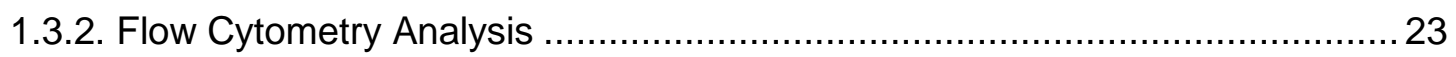

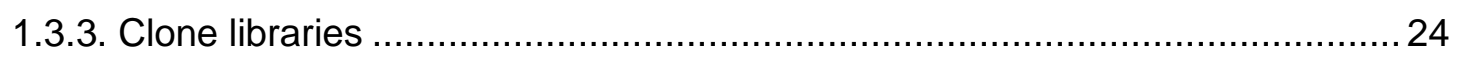

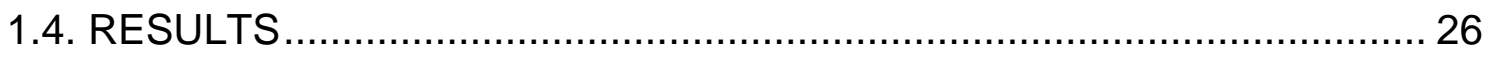

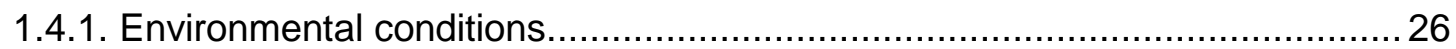

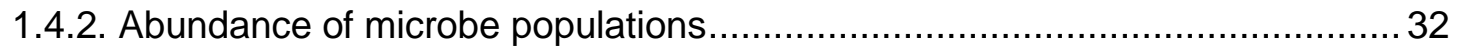

1.4.3. Carbon biomass of microbe populations ................................................... 40

1.4.4. Pico and nano-phytoplankton phylogenetic composition................................ 46

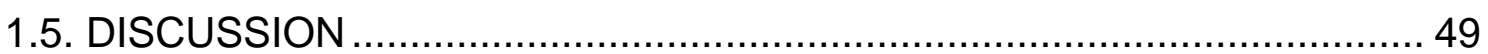

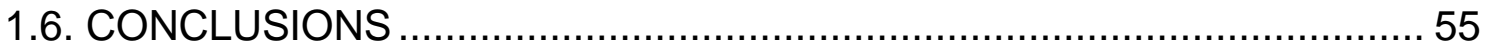

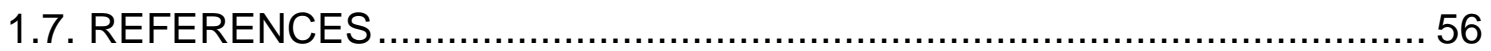

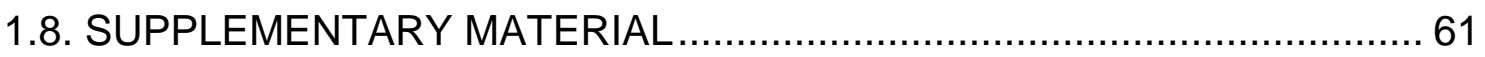




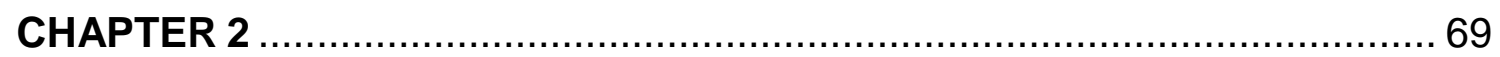

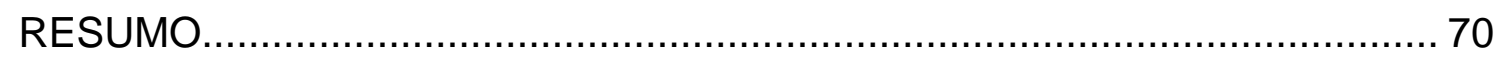

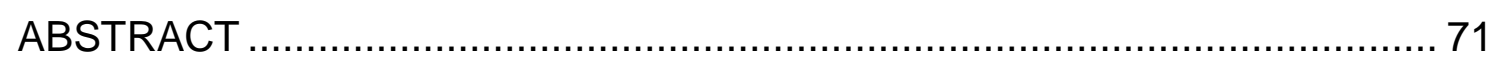

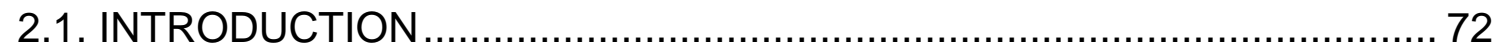

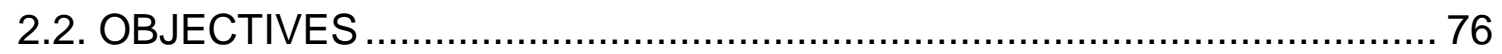

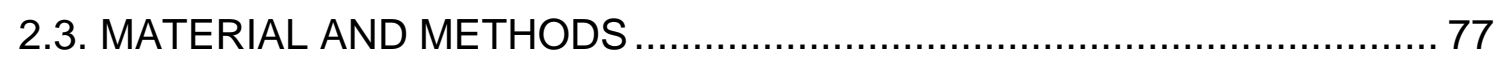

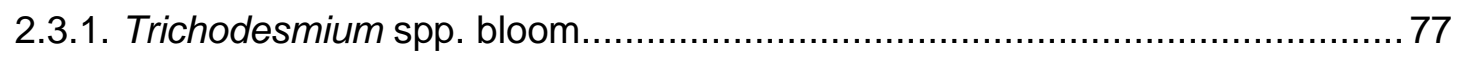

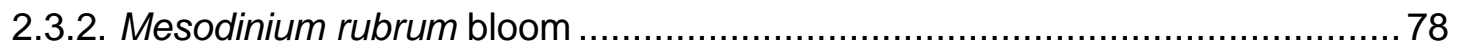

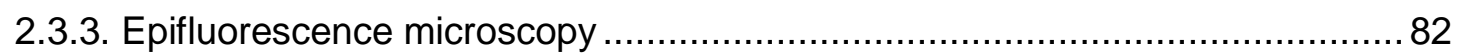

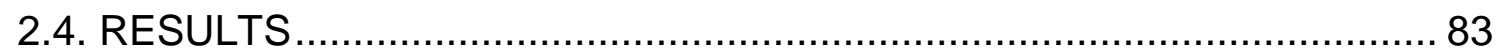

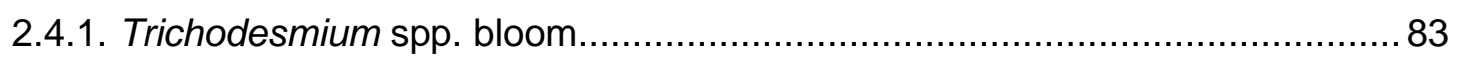

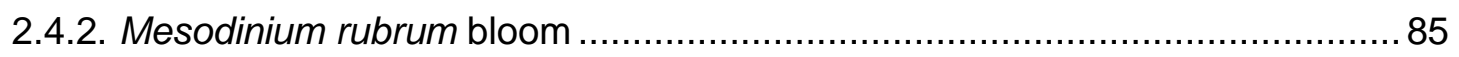

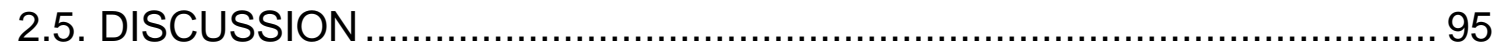

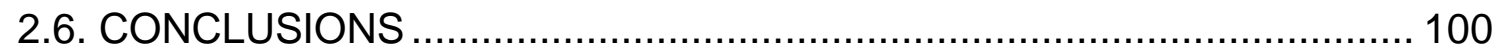

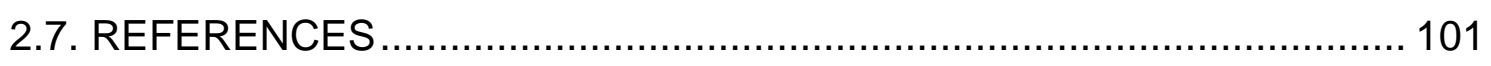

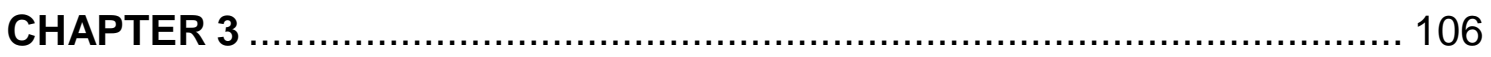

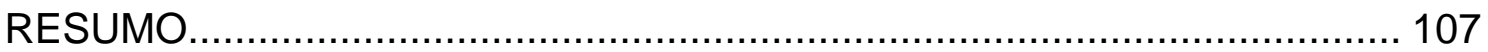

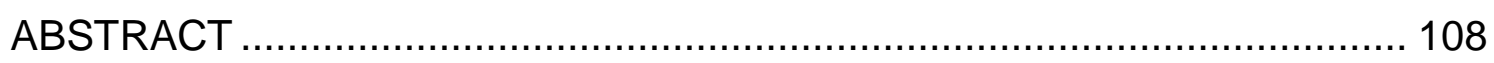

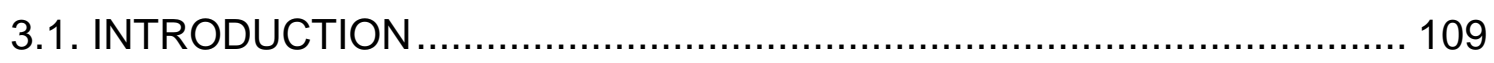

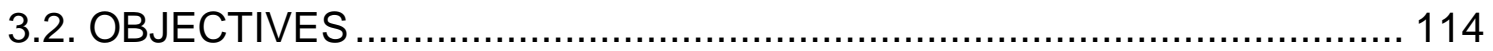

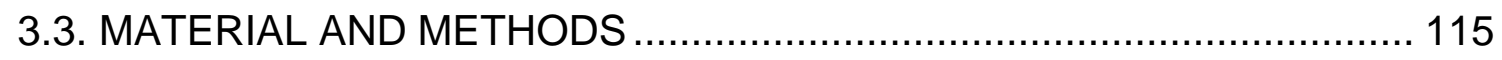

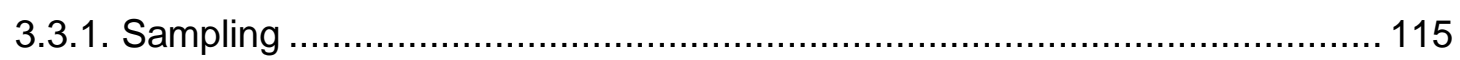

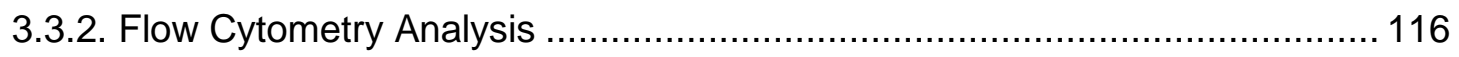

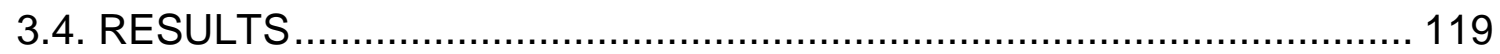

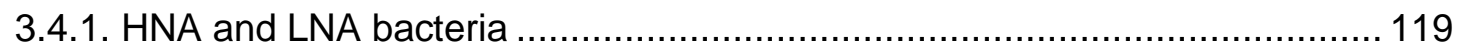

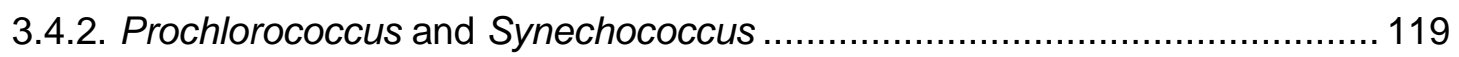

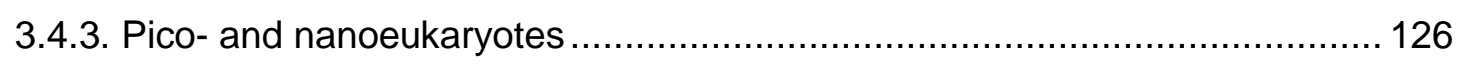

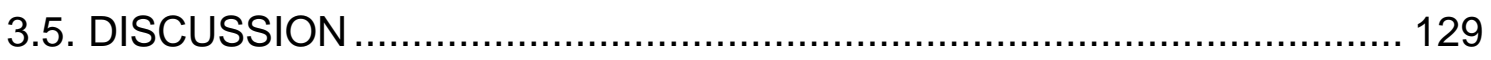

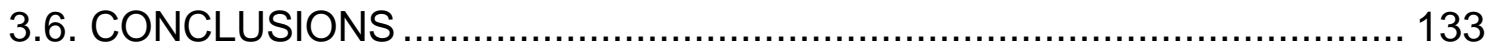

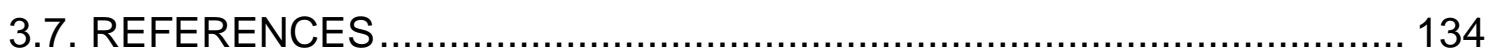




\section{LIST OF FIGURES}

Figure 1. General schematic figure showing the main systems of a flow cytometer, including fluidics, optics, electronics and sorting systems . Reprinted from PICOT et al., (2012).

Figure 2. Oceanic food web showing the role of picoplankton on the paths of organic carbon flux. Reprinted from BARBER (2007). 6

Figure 3. Planktonic groups analyzed in the present work (purple) and their subdivisions. Subgroups are marked in orange (heterotrophic), and green (autotrophic)

Figure 1.1. Location of sampling stations in the SAO off Brazil (11-18 November 2013). Profiles: transect 1 (TR1, St.81 to 92) and transect 2 (TR2, St.96 to 114), represented by black dots; Surface sampling: transect 3 (TR3, St.133 to 147), represented by black triangles. Sampling stations where $16 \mathrm{~S}$ rRNA partial sequences were retrieved are marked with a circle. The asterisk represent the TRICHO station, inside a Trichodesmium spp. bloom.

Figure 1.2. Vertical distribution of temperature $\left(\mathrm{T}^{\circ} \mathrm{C}\right)$ and salinity, for transect 1 (A, B) and transect 2 (C, D); numbers indicate sampling stations; black dots indicate sampling depths; water masses are delimitated in white: Tropical Water (TW); South Atlantic Central Water (SACW) and Coastal Water (CW). 28

Figure 1.3. Vertical distribution of fluorescence (RFU) and nitrate $\left(\mu M . L^{-1}\right)$, for transect $1(\mathrm{~A}, \mathrm{~B})$ and transect $2(\mathrm{C}, \mathrm{D})$; numbers indicate sampling stations; black dots indicate sampling depths; water masses are delimitated in white: Tropical Water (TW); South Atlantic Central Water (SACW) and Coastal Water (CW).

Figure 1.4. Vertical distributions of phosphates $\left(\mu \mathrm{M} \mathrm{L}^{-1}\right)$, for transect $1(\mathrm{~A})$ and transect $2(B)$; numbers indicate sampling stations; black dots indicate sampling depths; water masses are delimitated in white: Tropical Water (TW); South Atlantic Central Water (SACW) and Coastal Water (CW). 30

Figure 1.5. Surface distribution of temperature $\left(T^{\circ} \mathrm{C}\right)(A)$, salinity $(B)$, fluorescence (RFU) $(C)$, nitrates $\left(\mu M . L^{-1}\right)(D)$ and phosphates $\left(\mu M . L^{-1}\right)(E)$ for transect 1,2 and 3; numbers indicate the beginning and the end of each transect; black dots indicate each station. 
Figure 1.6. Vertical distribution of total heterotrophic bacteria and Prochlorococcus (in cells. $\mathrm{mL}^{-1}$ ), for transect 1 (A, B) and transect 2 (C, D); numbers indicate sampling stations; black dots indicate sampling depths; water masses are delimitated in white: Tropical Water (TW); South Atlantic Central Water (SACW) and Coastal Water (CW).

Figure 1.7. Vertical distribution of Synechococcus and picoeukaryotes (in cells. $\left.\mathrm{mL}^{-1}\right)$, for transect $1(\mathrm{~A}, \mathrm{~B})$ and transect $2(\mathrm{C}, \mathrm{D})$; numbers indicate sampling stations; black dots indicate sampling depths; water masses are delimitated in white: Tropical Water (TW); South Atlantic Central Water (SACW) and Coastal Water (CW). 36

Figure 1.8. Vertical distribution of: nanoeukaryotes (in cells. $\mathrm{mL}^{-1}$ ), for transect 1 (A) and transect 2 (B); numbers indicate sampling stations; black dots indicate sampling depths; water masses are delimitated in white: Tropical Water (TW); South Atlantic Central Water (SACW) and Coastal Water (CW) .................... 37

Figure 1.9. Surface distribution of total heterotrophic bacteria $(A)$, Prochlorococcus (B), Synechococcus (C), picoeukaryotes (D) and nanoeukaryotes (E) (in cells. $\mathrm{mL}^{-1}$ ) for transect 1,2 and 3; numbers indicate the beginning and the end of each transect; black dots indicate each station........ 38

Figure 1.10. Principal Component Analysis (PCA) showing (A) total heterotrophic bacteria, Prochlorococcus, Synechococcus, picoeukaryotes, nanoeukaryotes and chlorophyll fluorescence distributions (supplementary variables) in relation with temperature, salinity, nitrates and phosphates; (B) distribution of the stations. Dashed ellipse indicates samples from Coastal Water (CW), dashed square indicates the zoom window; \#96 refers to samples from St. 96. 39

Figure 1.11. Biomass $\left(\mu \mathrm{gC} \cdot \mathrm{mL}^{-1}\right)$ estimated for total heterotrophic bacteria (BACT), Prochlorococcus (PRO), Synechococcus (SYN) and picoeukaryotes (PEUK) for TR1(A), TR2 (B) and TR3 (C). Note that the scale for TR1 is different from TR2 and TR3. 41

Figure 1.12. Vertical distribution of total autotrophic biomass $\left(\mu \mathrm{gC} . \mathrm{L}^{-1}\right)$ and relative contribution to total biomass (\%) of total heterotrophic bacteria for transect 1 (A, B) and transect 2 (C, D); numbers indicate sampling stations; black dots indicate sampling depths; water masses are delimitated in white: Tropical Water (TW); South Atlantic Central Water (SACW) and Coastal Water (CW). 
Figure 1.13. Vertical distribution of relative contribution to total biomass (\%) of Prochlorococcus and Synechococcus for transect 1 (A, B) and transect 2 (C, D); numbers indicate sampling stations; black dots indicate sampling depths; water masses are delimitated in white: Tropical Water (TW); South Atlantic Central Water (SACW) and Coastal Water (CW).

Figure 1.14. Vertical distribution of relative contribution to total biomass (\%) of picoeukaryotes for transect 1 (A) and transect 2 (B); numbers indicate sampling stations; black dots indicate sampling depths; water masses are delimitated in white: Tropical Water (TW); South Atlantic Central Water (SACW) and Coastal Water (CW). 44

Figure 1.15. Surface distribution of total autotrophic biomass $\left(\mu g C . L^{-1}\right)(A)$, relative contribution to total biomass (\%) of total heterotrophic bacteria (B), Prochlorococcus (C), Synechococcus (D) and picoeukaryotes (E) for transect 1 , 2 and 3; numbers indicate the beginning and the end of each transect; black dots indicate each station.

Figure 1.16. Phylogenetic tree of plastid 16S rRNA gene sequences. Sequences were retrieved from photosynthetic pico- and nanoeukaryotes sorted by flow cytometry in the Southwest Atlantic Ocean. The tree is inferred from 537 positions of an alignment of 25 partial sequences. The phylogenetic tree was constructed by the maximum likelihood (ML) method based on a TN93 (Tamura-Nei) model of nucleotides substitution. Bootstrap values over $50 \%$ are indicated on the internal branches. Sequences in bold are representative of OTUs obtained in the present study. Red and blue labeling refers to sequences retrieved from the pico- and nanoplankton, respectively. Numbers with symbols correspond to the number of clones retrieved for each OTU.

Figure 1.17. Composition of $16 \mathrm{~S}$ rRNA sequences (total of 30 sequences) from pico- and nanoplanktonic sorted cells at three stations. 48

Figure S1. Temperature-Salinity (T-S) diagram generated with CTD dataset showing the water masses sampled in this study (open black boxes), with the depth on which they were found (Z axis, colorbar): Tropical Water (TW); South Atlantic Central Water (SACW) and Coastal Water (CW). 61

Figure S2. Representation of the seasonal intrusion of South Atlantic Central Water (SACW) over the bottom of the continental shelf, which is enhanced during summer, due to offshore Ekman transport of surface waters. CW: Coastal Water; TW: Tropical Water. Reprinted from (CAMPOS; VELHOTE; SILVEIRA, 2000). 62 
Figure 2.1. Schematic model of the impact of a Trichodesmium spp. bloom in the water column community (reproduced from Hynes et al., 2009).

Figure 2.2. Location of sampling stations in the $S A O$ off Brazil, corresponding to two cruises: Trichodesmium spp. bloom (St. T100 and St. T101) in November/2013 (shaded dots) and Mesodinium rubrum bloom (St. M1, St. M3, St. M5, St. M7 and St. M9) in July/2014 (shaded squares). Sampling stations right above the blooms are marked with a star (TRICHO and MR1/MR3) ........ 80

Figure 2.3. A) Satellite imagery (MODIS - Moderate Resolution Imaging Spectroradiometer) showing mean surface chlorophyll concentration $\left(\mathrm{mg} \cdot \mathrm{m}^{3}\right)$ in the Trichodesmium spp. bloom area, during its occurrence (3-days compilation). B) Satellite imagery (MODIS) showing the extension of the M. rubrum in the Brazilian coast. 81

Figure 2.4. A) Abundance (in cells. $\mathrm{mL}^{-1}$ ) and $\mathrm{B}$ ) relative contribution (in percentage) of HNA (dark purple) and LNA (light purple), for both $M$. rubrum (MR1 to MR15) and Trichodesmium spp. bloom (TRICHO and adjacent sampling stations, T100 and T101). Shaded stars represent samples immediately above the blooms. 88

Figure 2.5. A) Abundance (in cells. $\mathrm{mL}^{-1}$ ) and B) relative contribution (in percentage) of Prochlorococcus (dark green) and Synechococcus (lime green), for both M. rubrum (MR1 to MR15) and Trichodesmium spp. bloom (TRICHO and adjacent sampling stations, T100 and T101). Shaded stars represent samples immediately above the blooms. 89

Figure 2.6. A) Abundance (in cells. $\mathrm{mL}^{-1}$ ) and B) relative contribution (in percentage) of picoeukaryotes (dark blue), nanoeukaryotes (light blue) and phycoerythrin-containing eukaryotes (red), for both M. rubrum (MR1 to MR15) and Trichodesmium spp. bloom (TRICHO and adjacent sampling stations, T100 and T101). Shaded stars represent samples immediately above the blooms. . 90

Figure 2.7. Cytograms of A) Phycoerythrin versus Chlorophyll and B) SSC (side scatter) versus Chlorophyll data of sample MR3, showing the following gating patterns: Prochlorococcus (pink), Synechococcus (green), picoeukaryotes (blue), nanoeukaryotes (yellow) and phycoerythrin-containing eukaryotes (presumably Cryptophyta) (orange). Calibrations beads are marked in black. . 91

Figure 2.8. A) Biomass (in $\mu \mathrm{gC} . \mathrm{L}^{-1}$ ) and B) its relative contribution (in percentage) of picoeukaryotes (light green), Synechococcus (red), Prochlorococcus (yellow), HNA (purple) and LNA (blue) bacteria, for both $M$. rubrum (MR1 to MR15) and Trichodesmium spp. bloom (TRICHO and adjacent sampling stations, T100 and T101). Shaded stars represent samples immediately above the blooms. 92 
Figure 2.9. Epifluorescence microscopy images from the Trichodesmium spp. bloom, showing the following features: A) different pigmentation; B) tuft morphology of the colonies; C) different terminations; D) diazocytes; $E, F$ ) accumulation of genetic material and $\mathrm{G}, \mathrm{H}$ ) epibiont community.................... 93

Figure 2.10. Possible kleptoplasty occurrence between Mesodinium rubrum and cryptophyte captured on light microscopy image from the M. rubrum cruise. Credits: Catherine G. Ribeiro. Samples were courtesy of Salvador Airton Gaeta and Mayza Pompeu (LaPP/IOUSP). 94

Figure 2.11. Phycoerythrin fluorescence from Mesodinium rubrum captured on epifluorescence microscopy image from the $M$. rubrum cruise. Credits: Catherine G. Ribeiro. Samples were courtesy of Salvador Airton Gaeta and Mayza Pompeu (LaPP/IOUSP)........................................................... 94

Figure 3.1. Cytograms of Phycoerythrin versus Chlorophyll of sample 137 (St. 100, 110 meters depth) from A) BD FACSCanto ${ }^{\mathrm{TM}}$ and B) BD Accuri ${ }^{\mathrm{TM}}$ C6 readings, showing the following gating patterns: Prochlorococcus (pink), Synechococcus (green), picoeukaryotes (blue) and nanoeukaryotes (yellow). Calibrations beads are marked in black. 111

Figure 3.2. Location of sampling stations in the SAO off Brazil. Profiles: transect 1 (TR1, shaded circles) ; transect 2 (TR2, shaded triangles) and surface sampling, transect 3 (TR3, shaded squares). The color bar in the left indicates bottom depths. 118

Figure 3.3. Examples of red fluorescence distribution (number of events versus fluorescence intensity) from different depths of A) Prochlorococcus and B) Synechococcus recorded with BD FACSCanto ${ }^{\mathrm{TM}}$. Samples and their respective depths are described in the right. 121

Figure 3.4. Examples of red fluorescence distribution (number of events versus fluorescence intensity) from different depths of A) Prochlorococcus and B) Synechococcus recorded with BD Accuri ${ }^{\mathrm{TM}}$ C6. Samples and their respective depths are described in the right. 122

Figure 3.5. Relationship between abundance measurements performed with BD Accuri ${ }^{\mathrm{TM}} \mathrm{C} 6$ e BD FACSCanto ${ }^{\mathrm{TM}}$ (in cells. $\mathrm{mL}^{-1}$ ): (A) HNA bacteria; (B) LNA bacteria; (C) Prochlorococcus; (D) Synechococcus; (E) picoeukaryotes and (F) nanoeukaryotes. Regarding correction in red fluorescence distribution, points are marked as: 'no correction': black shaded circles, 'correction': grey shaded squares; outliers: open triangles. The coefficient of determination and the equation are indicated on each graphic. The regression line is marked in grey for points with no correction and in black for 'correction' samples, although being totally superimposed in Prochlorococcus regression (C). 123 
Figure 3.6. Examples of discriminated depth profiles (St. 100 and St. 114) of normalized red fluorescence distribution (chlorophyll versus relative cell number) and respective cell abundance of Prochlorococcus (A:L) and Synechococcus (M:X) on BD FACSCanto ${ }^{\mathrm{TM}}$ and BD Accuri ${ }^{\mathrm{TM}} \mathrm{C6}$. In the depth profiles ( $F, L, R, X)$, black shaded represents 'no correction' samples; grey shaded squares indicates 'correction' samples; samples within the noise were suppressed.

Figure 3.7. Comparison between measurements with BD FACSCanto ${ }^{\mathrm{TM}}(\mathrm{A}, \mathrm{B})$ and $\mathrm{BD}$ Accuri ${ }^{\mathrm{TM}} \mathrm{C} 6(\mathrm{C}, \mathrm{D})$ regarding the vertical abundance distribution (in cells. $\mathrm{mL}^{-1}$ ) of Prochlorococcus; numbers in the top indicate sampling stations; sampling points are marked as: 'no correction': black shaded circles, 'correction': grey shaded squares; outliers: open triangles, 'cells in noise': open circles.

Figure 3.8. Comparison between measurements with BD FACSCanto ${ }^{\mathrm{TM}}(\mathrm{A}, \mathrm{B})$ and $\mathrm{BD}$ Accuri ${ }^{\mathrm{TM}} \mathrm{C} 6(\mathrm{C}, \mathrm{D})$ regarding the vertical abundance distribution (in cells. $\mathrm{mL}^{-1}$ ) of Synechococcus; numbers in the top indicate sampling stations; sampling points are marked as: 'no correction': black shaded circles, 'correction': grey shaded squares; outliers: open triangles, 'cells in noise': open circles. 


\section{LIST OF TABLES}

Table 2.1. List of stations, samples and depths from the Trichodesmium spp. and $M$. rubrum cruise.

Table 3.1. Technical features of BD FACSCanto ${ }^{\mathrm{TM}}$ and BD Accuri ${ }^{\mathrm{TM}} \mathrm{C} 6$ flow cytometers

Table 3.2. Number of samples assigned as 'correction', 'no correction' and 'cells in noise' for each picocyanobacterial group and equipment tested. 126 


\section{ACKNOWLEDGMENTS / AGRADECIMENTOS}

Ao Instituto Oceanográfico da Universidade de São Paulo pela oportunidade de formação em um centro do excelência e por todo suporte científico, técnico e administrativo.

Ao prof. Dr. Frederico Pereira Brandini, meu orientador, pelas frutíferas e longas conversas sobre ciência e arte. Muito grata por todo conhecimento adquirido, pela amizade e apoio, e por me permitir alçar vôos intelectuais, sendo sempre um porto seguro.

À prof ${ }^{a}$. Dr ${ }^{\text {a }}$. Vivian Helena Pellizari, e a todos do LECOM, em especial à Rosa, Natascha, Amanda, Adriana, Diego, Felipe, Luana, Vítor, Marina, Francielli, Luciano e Rubens, pelo apoio no desenvolvimento do projeto e pelas deliciosas horas de descontração.

Ao Dr. Daniel Vaulot, sem o qual este trabalho não teria sido possível. Muito grata pelo apoio e pela oportunidade de ver tanto a ciência quanto o mundo com novos olhos.

À $\mathrm{Dr}^{\mathrm{a}}$. Adriana Lopes dos Santos, pelo valioso suporte científico e laboratorial, mas principalmente pela amizade, pelas risadas e panachés.

À toda equipe da Station Biologique de Roscoff pela hospitalidade e apoio, em especial ao Dominique Marie pelo carinho e ajuda com as amostras de citometria de fluxo e à Margot Tragin, pelo sorriso que alegra qualquer dia.

Aos membros da banca julgadora, por gentilmente aceitarem o convite.

Aos colegas de laboratório e de embarque, em especial à Mayza Pompeu, Pedro Marone, Pedro Guy e Mateus Chuqui.

Ao capitão e à tripulação do N/Oc. Alpha Crucis, assim como ao prof. Dr. Ilson da Silveira, que liderou o CARBOM V e que muito gentilmente deu todo apoio necessário para realização do campo. 
À Fundação de Amparo à Pesquisa do Estado de São Paulo (FAPESP), pelo auxílio financeiro sob os processos 2012/04800-9 e 2014/15242-2.

À Coordenação de Aperfeiçoamento de Pessoal de Nível Superior (CAPES).

Ao Clube do Almoço Filosófico, pelas incontáveis horas de viagem pelo Universo e suas peculiaridades.

Aos meus familiares e amigos, por serem a força motriz da minha vida. Sou muito grata por compreenderem as longas ausências e por todo o incentivo.

Ao meu noivo e melhor amigo Rafael Rotelok, por sempre me motivar a seguir em frente.

Agradeço a todos que foram facilitadores direta ou indiretamente para a realização desta tese. 
Para Rafaela Travensolli, Com amor, gratidão e saudade C 
"Curiouser and curiouser..."

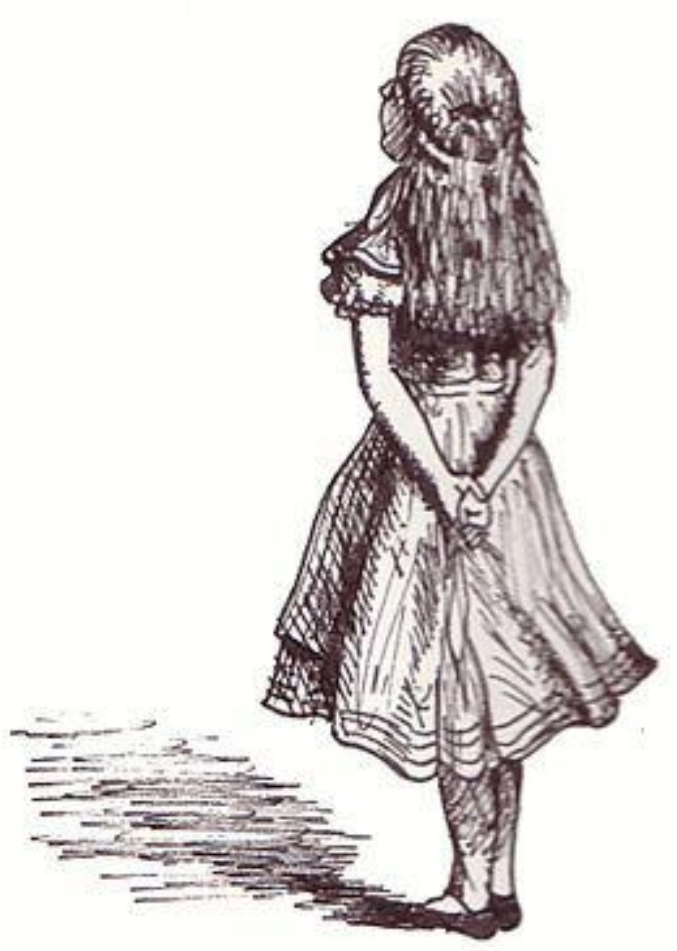

- Lewis Carroll, Alice's Adventures in Wonderland 


\section{RESUMO}

A citometria de fluxo (FCM, sigla em inglês) é uma técnica bem estabelecida, usada para enumeração e caracterização de partículas biológicas marinhas, a qual supre a demanda científica por automação rápida de contagem de células. A FCM permite a discriminação de populações pico- e nanoplanctônicas no que concerne à sua abundância, tamanho de célula e pigmentação, tanto por fluorescência natural ou induzida. A cianobactéria Prochlorococcus é amplamente disseminada pela zona eufótica dos oceanos tropicais e subtropicais, sendo considerada o menor e mais abundante organismo fotossintético do planeta. Synechococcus, outro importante gênero de cianobactérias presente no picoplâncton, é diverso e amplamente distribuído em ecossistemas marinhos, de águas frias e mesotróficas à regiões oceânicas quentes e de águas oligotróficas. Pico- e nanoeucariotos fotossintéticos apresentam uma grande variedade de fisiologias e estratégias de vida. Embora a abundância destes grupos seja geralmente menor, o maior tamanho de suas células resulta numa contribuição significante dos mesmos para a biomassa da comunidade epipelágica. Na presente tese eu objetivei investigar a abundância e a distribuição da biomassa de carbono de bactérias heterotróficas, Prochlorococcus, Synechococcus, pico- e nanoeucariotos autotróficos no sudoeste do Oceano Atlântico ao largo do Brasil, sua relação com as diferentes massas d'água e a influência de processos hidrodinâmicos (como a intrusão da Água Central do Atlântico Sul) e biológicos (florações de Trichodesmium spp. e Mesodinium rubrum) em tais distribuições.

Palavras-chave: citometria de fluxo, bactérias heterotróficas, Prochlorococcus, Synechococcus, picoeucariotos, nanoeucariotos, sudoeste do Atlântico Sul. 


\section{ABSTRACT}

Flow cytometry (FCM) is a well established technique used for enumeration and characterization of marine biological particles, which fulfills the scientific demands of rapid cell counting automation. FCM allows the discrimination of pico- and nanoplankton populations regarding its abundance, cell size, and pigment content both by natural or induced fluorescence. The cyanobacterium Prochlorococcus is widespread in the euphotic zone of the tropical and subtropical oceans, and is considered the smallest and most abundant photosynthetic organism in the planet. Synechococcus, other important cyanobacterium genus present in the picoplankton, is highly diverse and is widely distributed in marine ecosystems from cold and mesotrophic, to warm, open ocean oligotrophic waters. Photosynthetic pico- and nanoeukaryotes display a range of physiologies and life strategies. Although its abundance is generally lower, the larger cell size leads to a significant contribution to the epipelagic community biomass. In this thesis I aimed to investigate the abundance and carbon biomass distribution of heterotrophic bacteria, Prochlorococcus, Synechococcus, autotrophic pico- and nanoeukaryotes in the Southwest Atlantic Ocean off Brazil, their relation to the different water masses and the influence of hydrodynamic (South Atlantic Central Water intrusion) and biological processes (Trichodesmium spp. and Mesodinium rubrum blooms) on such distributions.

Keywords: flow cytometry, heterotrophic bacteria, Prochlorococcus, Synechococcus, picoeukaryotes; nanoeukaryotes, Southwest Atlantic Ocean. 


\section{GENERAL INTRODUCTION}

FCM is a well established technique (GASOL; DEL GIORGIO, 2000; MARIE et al., 1997) used since 1980s (TRASK; VAN DEN ENGH; ELGERSHUIZEN, 1982) for enumeration and characterization of marine biological particles. FCM analysis of planktonic communities fulfills the scientific demands of rapid and accurate cell counting automation, as it eliminates the bias introduced by human counting (MARIE; SIMON; VAULOT, 2005; VAULOT et al., 2008). By simultaneously recording several parameters during analysis, FCM allows the discrimination of pico- and nanoplankton populations regarding its abundance, cell size, and pigment content (MARIE; SIMON; VAULOT, 2005), both by natural (chlorophyll, phycoerythrin) or induced fluorescence (fluorescent dyes) (MARIE et al., 1997).

The flow cytometer registers events as aligned cells in a fluid stream flow through a beam of light, reflecting or refracting it. This pulse, which is dependent of the refractive index, size, and shape of the flowing particle, is recorded and converted to a digital signal (MARIE; SIMON; VAULOT, 2005). A flow cytometer comprises three main systems: fluidics (particle's transport), optics (laser beam and optical filters), and electronics (signal conversion into electronic data) (Figure 1). Detectors located from the light source at $180^{\circ}$ and $90^{\circ}$ are called forward scatter (FSC) and side scatter (SSC), respectively. Beyond information about the size of the particle, SSC records cells features regarding its rugosity and internal structure (MARIE; SIMON; VAULOT, 2005). The converted signal from each parameter is displayed as cytograms, which are 
used to specify and count different populations, based on distinctive pigment contents and/or peculiar morphological features. To 'gate' a specific population on a cytogram means to define its relative position on bivariate dot plots representing fluorescence and SSC/FSC data (Figure 1).

The use of FCM in order to select cells with particular fluorescence characteristics (fluorescence-activated cell sorter, or FACS) began in the late 1960s, primarily for sorting viable cells for enrichments (HERZENBERG et al., 2002). Now, the combination of FCM, cell sorting and molecular biology is allowing an unprecedented leap in the understanding of the ecological particularities of the smaller size fractions of the phytoplankton (WANG et al., 2010).

Another great advance for FCM-based oceanographic studies came with the manufacturing of small benchtop flow cytometers, which are compact, easyto-use and with more affordable prices (PICOT et al., 2012).

Although FCM can be employed in oceanographic studies to survey the cell characteristics of large marine organisms, its use have been focused mainly on marine microorganisms (PICOT et al., 2012). Pico-phytoplankton includes both photosynthetic prokaryotes and eukaryotes, and its significance arises from its ubiquity, abundance and persistency, strongly impacting the primary productivity and carbon cycling in the marine environment (GROB et al., 2007; LI, 1994; RICHARDSON; JACKSON, 2007; WORDEN et al., 2004). 


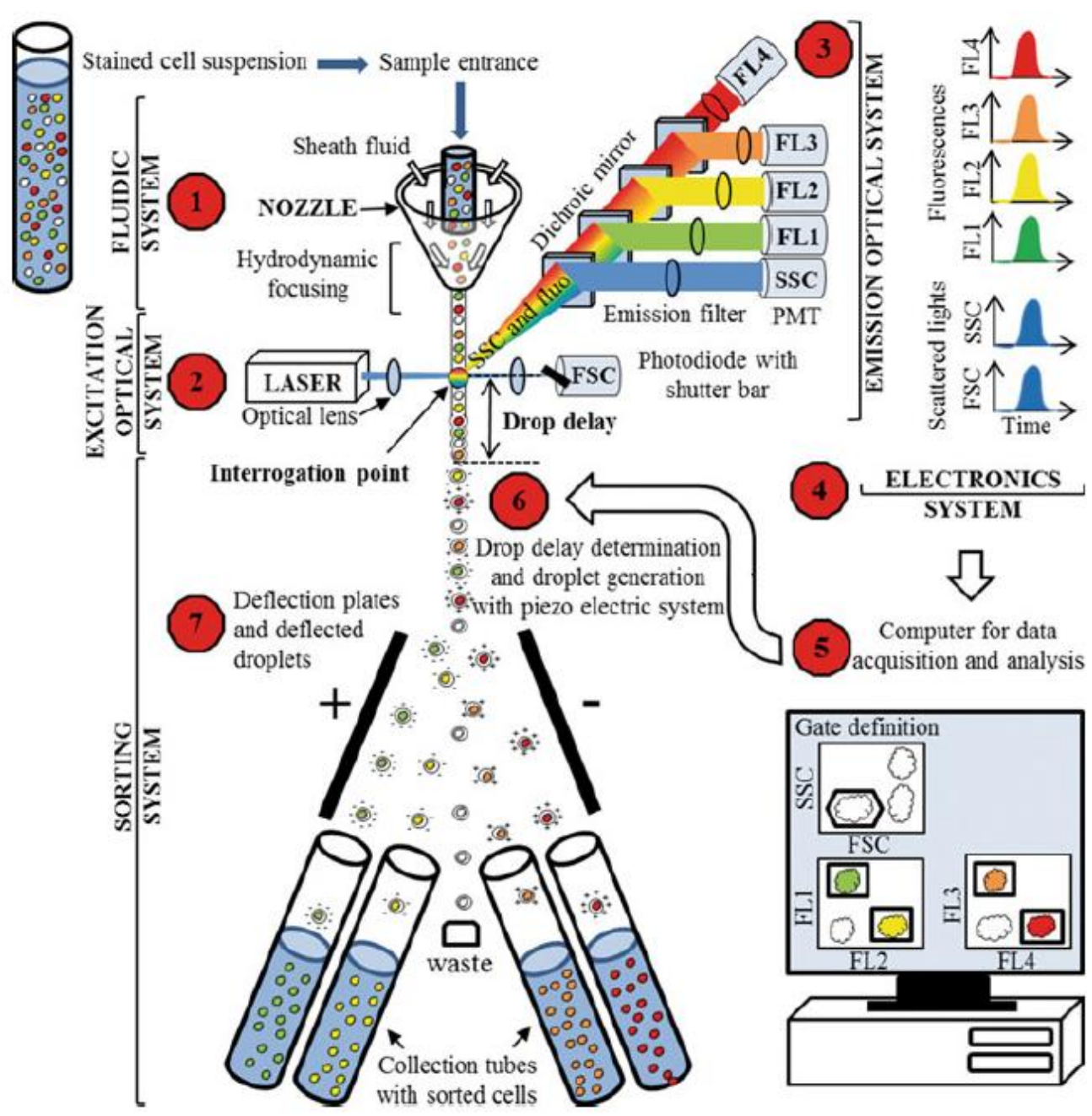

Figure 1. General schematic figure showing the main systems of a flow cytometer, including fluidics, optics, electronics and sorting systems . Reprinted from PICOT et al., (2012). 
Despite of its small size compared to the other components of the plankton, recent studies show that the picoplankton may transfer much more newly synthesized carbon than previously thought, being important carbon export agents, both via aggregate formation or consumption by higher trophic level organisms, like large zooplankton (RICHARDSON; JACKSON, 2007) (Figure 1.2). Pico-phytoplankton may account to up to $60 \%$ of the chlorophyll-a and primary production in some regions of the Atlantic Ocean (PÉREZ et al., 2005), with highest contribution in tropical and oligotrophic waters (AGAWIN; DUARTE; AGUSTI, 2000).

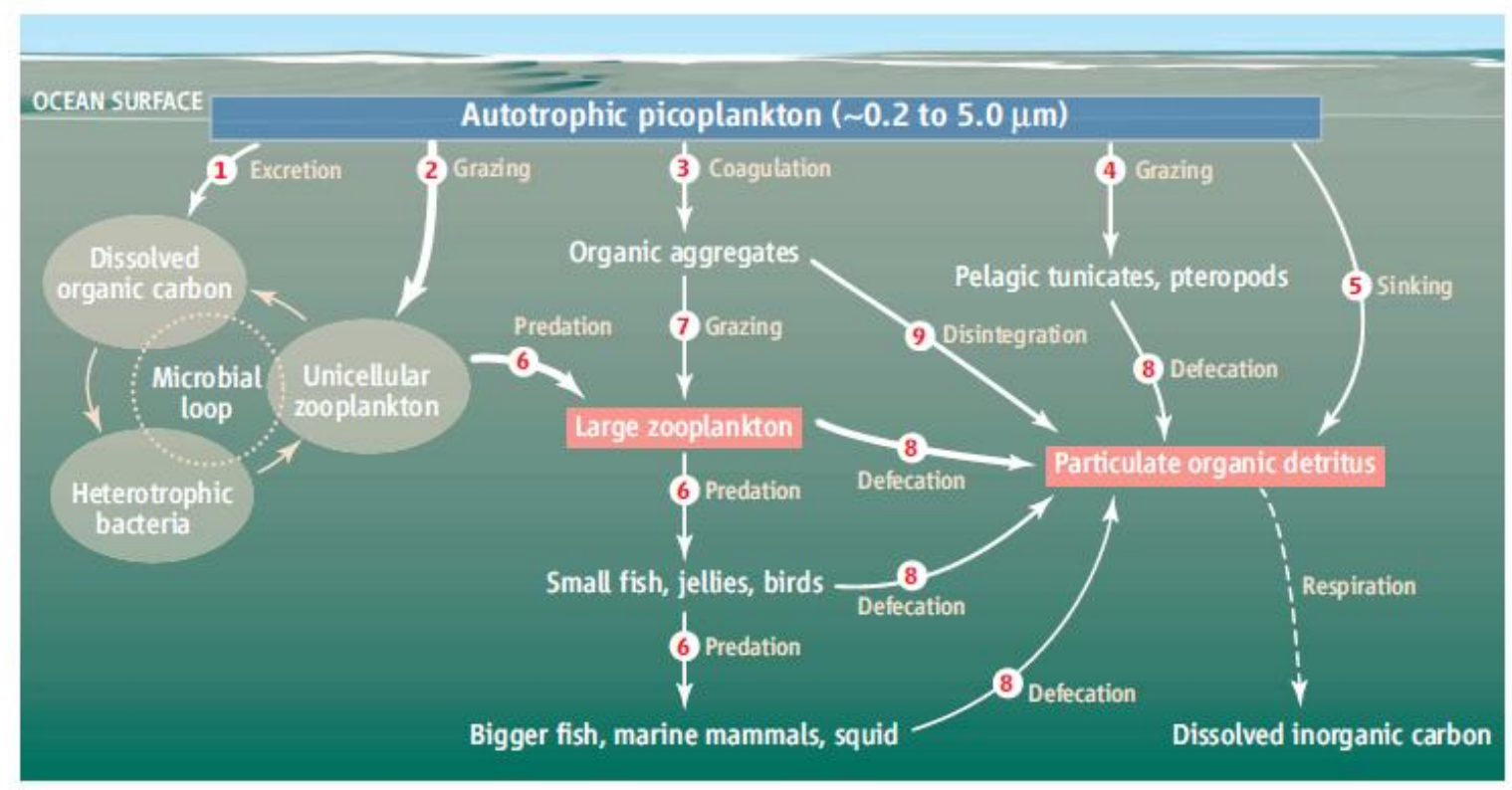

Figure 2. Oceanic food web showing the role of picoplankton on the organic carbon flux. Reprinted from BARBER (2007). 
The cyanobacterium Prochlorococcus (PRO) is widespread in the euphotic zone of the tropical and subtropical oceans, and is considered the smallest and most abundant photosynthetic organism in the planet (PARTENSKY; HESS; VAULOT, 1999). Its broad genomic and phenotypic diversity ensures PRO a wide distribution $\left(40^{\circ} \mathrm{N}\right.$ to $40^{\circ} \mathrm{S}$ ) (JOHNSON et al., 2006) and high, stable abundance throughout the oceans (BILLER et al., 2015; KASHTAN et al., 2014), responsible for a projected carbon fixation of 4 Gt.C. ${ }^{-1}$, approximately $9 \%$ of ocean's net primary production (FLOMBAUM et al., 2013). Synechococcus (SYN), the other important cyanobacterium genus present in the pico-phytoplankton, is highly diverse (with more than 20 genetically distinct clades) (SOHM et al., 2015) and is widely distributed in marine ecosystems (PARTENSKY; BLANCHOT; VAULOT, 1999; ZUBKOV et al., 1998) from cold and mesotrophic, to warm, open ocean oligotrophic waters. SYN may account for up to $17 \%$ of net primary production in the oceans (FLOMBAUM et al., 2013). Photosynthetic pico-eukaryotes (PEUK) display a range of physiologies and life strategies, with Chlorophyta, Heterokontophyta, and Haptophyta being the most important groups (WORDEN; NOT, 2008). PEUK abundance is generally lower than for SYN and PRO, but its larger cell size leads to a significant contribution to the epipelagic community biomass (GUO et al., 2014; WORDEN; NOT, 2008; WORDEN et al., 2004; ZUBKOV et al., 1998). 
In the present work I intended to investigate the abundance and carbon biomass distribution of heterotrophic bacteria, Prochlorococcus, Synechococcus, autotrophic pico- and nanoeukaryotes (Figure 3) in the Southwest Atlantic Ocean off Brazil (SAO). The first chapter presents a study on how the different water masses influence the pico- and nanoplankton distribution within the euphotic zone of SAO. A special attention was given to the effects of the South Atlantic Central Water intrusion over the bottom of the continental shelf, which causes an upward displacement of the thermocline and the fertilization of the euphotic layer. In Chapter 2 the influence of biological processes on pico- and nanoplankton distribution is investigated by flow cytometry analysis of two distinct blooms, the autotrophic Trichodesmium spp. and the mixotrophic Mesodinium rubrum. Chapter 3 explores whether measurements from different flow cytometers can impact the accuracy of output data, and if posterior correction based on red fluorescence distribution can minimize biased ecological inferences generated by low resolution equipments.

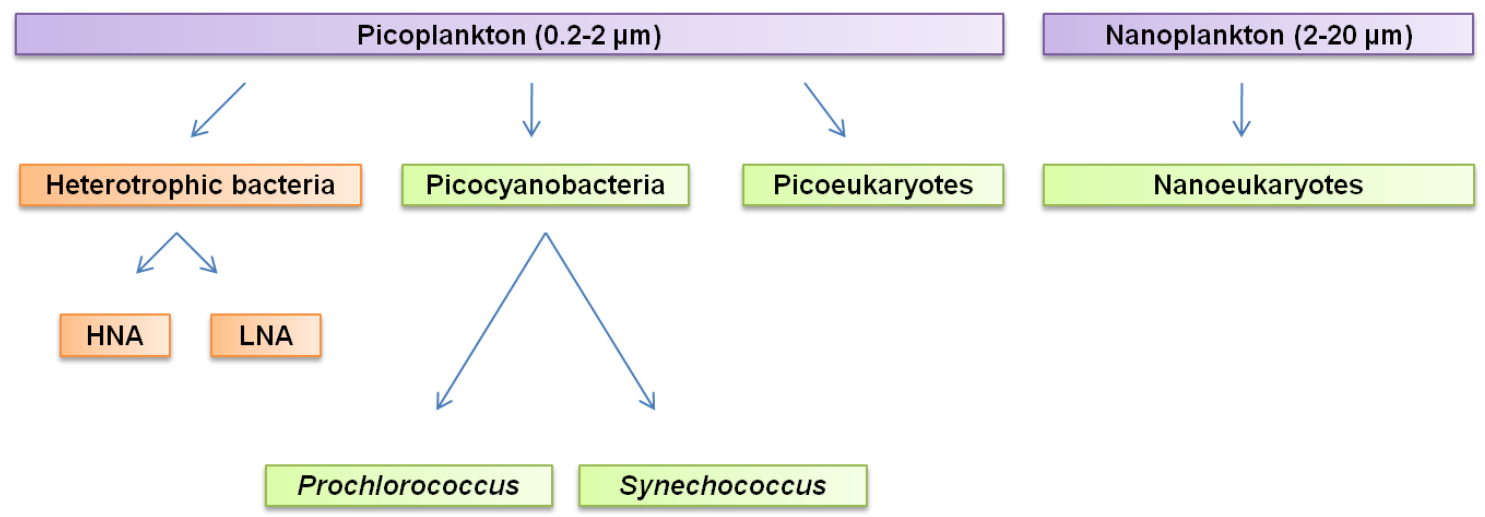

Figure 3. Planktonic groups analyzed in the present work (purple) and their subdivisions. Subgroups are marked in orange (heterotrophic), and green (autotrophic). 


\section{GENERAL OBJECTIVES}

This thesis was elaborated under the CARBOM Project (Environmental Characterization and Evaluation of Biogenic Ocean Resources of Brazilian Continental Margin and Adjacent Oceanic Area, acronym in Portuguese), which aimed to evaluate the role of oceanographic processes in the global carbon cycle.

Within this context, I intended to contribute by investigating the abundance and carbon biomass distribution of smaller size classes of the plankton, i. e. heterotrophic bacteria, Prochlorococcus, Synechococcus, autotrophic pico- and nanoeukaryotes, in the Southwest Atlantic Ocean off Brazil, and their relation to the different water masses in the region. 


\section{SPECIFIC OBJECTIVES}

\section{CHAPTER 1}

(A) To determine pico- and nanoplankton (heterotrophic bacteria, Prochlorococcus, Synechococcus, pico- and nanoeukaryotes) distributions by flow cytometry, as well as their contribution to carbon biomass in the South Atlantic Ocean off Brazil.

(B) To investigate whether and how pico- and nanoplankton dominance patterns are influenced by the hydrodynamic regime of the water masses in the region.

(C) To perform an initial prospect of pico- and nanoplankton diversity with a small 16S rRNA clone library.

\section{CHAPTER 2}

(A) To determine the abundance and biomass of heterotrophic bacteria and autotrophic pico- and nanoplankton in two functionally distinct blooms (Trichodesmium spp. and Mesodinium rubrum).

(B) To investigate the influence of the blooms on dominance patterns regarding picoplanktonic abundance and carbon biomass in the surrounding waters.

\section{CHAPTER 3}

(A) To assess whether the use of different flow cytometers (FACSCanto ${ }^{\mathrm{TM}}$ and Accuri $\mathrm{C}^{\mathrm{TM}}$ ) produce distinct results regarding picoplankton communities.

(B) To test if an indirect correction based on red fluorescence distribution can minimize underestimation of Prochlorococcus and Synechococcus populations. 


\section{REFERENCES}

AGAWIN, N.; DUARTE, C.; AGUSTI, S. Nutrient and temperature control of the contribution of picoplankton to phytoplankton biomass and production. Limnology and Oceanography, v. 45, n. 3, p. 591-600, 2000.

BARBER, R. T. Oceans. Picoplankton do some heavy lifting. Science (New York, N.Y.), v. 315, n. 5813, p. 777-778, 2007.

BILLER, S. J. et al. Prochlorococcus: the structure and function of collective diversity. Nature Publishing Group, v. 13, n. 1, p. 13-27, 2015.

FLOMBAUM, P. et al. Present and future global distributions of the marine Cyanobacteria Prochlorococcus and Synechococcus. Proceedings of the National Academy of Sciences, v. 110, n. 24, 2013.

GASOL, J. M.; DEL GIORGIO, P. A. Using flow cytometry for counting natural planktonic bacteria and understanding the structure of planktonic bacterial communities. Scientia Marina, v. 64, n. 2, p. 197-224, 2000.

GROB, C. et al. Contribution of picoplankton to the total particulate organic carbon concentration in the eastern South Pacific. Biogeosciences, v. 4, p. 837-852, 2007.

GUO, C. et al. Seasonal and spatial patterns of picophytoplankton growth, grazing and distribution in the East China Sea. Biogeosciences, v. 11, n. 7, p. 1847-1862, 8 abr. 2014.

HERZENBERG, L. A. et al. The history and future of the Fluorescence Activated Cell Sorter and flow cytometry: A view from Stanford. Clinical Chemistry, v. 48, n. 10, p. 1819-1827, 2002.

JOHNSON, Z. I. et al. Niche partitioning among Prochlorococcus ecotypes along ocean-scale environmental gradients. Science, v. 311, n. 5768, p. 17371740, 2006. 
KASHTAN, N. et al. Single-cell genomics reveals hundreds of coexisting subpopulations in wild Prochlorococcus. Science, v. 344, n. 6182, p. 416-20, 2014.

LI, W. K. W. Primary production of prochlorophytes, cyanobacteria, and eucaryotic ultraphytoplankton: Measurements from flow cytometric sorting. Limnology and Oceanography, 1994.

MARIE, D. et al. Enumeration and cell cycle analysis of natural populations of marine picoplankton by flow cytometry using the nucleic acid stain SYBR Green I. Applied and Environmental Microbiology, v. 63, n. I, p. 186-193, 1997.

MARIE, D.; SIMON, N.; VAULOT, D. Phytoplankton Cell Counting by Flow Cytometry. In: Algal culturing techniques. [s.l: s.n.]. p. 253-556.

PARTENSKY, F.; BLANCHOT, J.; VAULOT, D. Differential distribution and ecology of Prochlorococcus and Synechococcus in oceanic waters: a review. Bulletin de l'Institut océanographique, v. 19, p. 457-476, 1999.

PARTENSKY, F.; HESS, W. R.; VAULOT, D. Prochlorococcus, a marine photosynthetic prokaryote of global significance. Microbiology and Molecular Biology Reviews, v. 63, n. 1, p. 106-127, 1999.

PÉREZ, V. et al. Latitudinal distribution of microbial plankton abundance, production, and respiration in the Equatorial Atlantic in autumn 2000. Deep-Sea Research Part I: Oceanographic Research Papers, v. 52, p. 861-880, 2005.

PICOT, J. et al. Flow cytometry: retrospective, fundamentals and recent instrumentation. Cytotechnology, v. 64, n. 2, p. 109-30, mar. 2012.

RICHARDSON, T. L.; JACKSON, G. A. Small phytoplankton and carbon export from the surface ocean. Science (New York, N.Y.), v. 315, n. 5813, p. 838840, 9 fev. 2007.

SOHM, J. A et al. Co-occurring Synechococcus ecotypes occupy four major oceanic regimes defined by temperature, macronutrients and iron. The ISME Journal, p. 1-13, 2015. 
TRASK, B. J.; VAN DEN ENGH, G. J.; ELGERSHUIZEN, J. H. Analysis of phytoplankton by flow cytometry. Cytometry, v. 2, n. 4, p. 258-264, 1982.

VAULOT, D. et al. The diversity of small eukaryotic phytoplankton $(<$ or $=3$ microm) in marine ecosystems. FEMS microbiology reviews, v. 32, n. 5, p. 795-820, ago. 2008.

WANG, Y. et al. Past, present and future applications of flow cytometry in aquatic microbiology. Trends in Biotechnology, v. 28, n. Table 2, p. 416-424, 2010.

WORDEN, A. Z. et al. Assessing the dynamics and ecology of marine picophytoplankton: The importance of the eukaryotic component. Limnology and Oceanography, v. 49, n. 1, p. 168-179, 2004.

WORDEN, A. Z.; NOT, F. Ecology and Diversity of Picoeukaryotes. In: KIRCHMAN DL (Ed.). . Microbial Ecology of the Oceans: Second Edition. 2nd. ed. New York: Wiley-Liss, 2008. p. 159-205.

ZUBKOV, M. V et al. Picoplanktonic community structure on an Atlantic transect from $50^{\circ} \mathrm{N}$ to $50^{\circ} \mathrm{S}$. Deep Sea Research Part I: Oceanographic Research Papers, v. 45, n. 8, p. 1339-1355, ago. 1998. 


\section{CHAPTER 1}

Pico- and Nanoplankton Abundance and Biomass in the Southwest Atlantic Ocean off Brazil 


\section{Abbreviations}

BACT - bacteria and archaea

BTF - Bottom Thermal Front

CW - Coastal Water

DCM - Deep Chlorophyll Maximum

FCM - Flow Cytometry

NEUK - nanoeukaryotes

PCA - Principal Component Analysis

PEUK - picoeukaryotes

PRO - Prochlorococcus

SACW - South Atlantic Central Waters

SAO - Southwest Atlantic Ocean

SYN - Synechococcus

TW - Tropical Water 


\section{RESUMO}

A produtividade primária no sudoeste do Atlântico Sul (abaixo de $20^{\circ} \mathrm{S}$ ) é principalmente influenciada pela intrusão sazonal da Água Central do Atlântico Sul (ACAS), rica em nutrientes, ao longo do fundo da plataforma continental. Para investigar como este processo afeta as comunidades pico- e nanoplanctônicas, nós utilizamos a citometria de fluxo para determinar a abundância de bactérias heterotróficas, Prochlorococcus, Synechococcus, picoeucariotos e nanoeucariotos em três transectos ao longo da costa brasileira, de $23^{\circ} \mathrm{S}$ a $31^{\circ} \mathrm{S}$ e de $39^{\circ} \mathrm{W}$ a $49^{\circ} \mathrm{W}$. Populações de bactérias heterotróficas e Prochlorococcus foram abundantes na Água Costeira e Água Tropical, com $1,4 \times 10^{6}$ células. $\mathrm{mL}^{-1}$, e $0,3 \times 10^{6}$ células. $\mathrm{mL}^{-1}$, respectivamente. Altas abundâncias de Synechococcus foram encontradas em águas superficiais de plataforma. Pico- a nanoeucariotos foram particularmente importantes no Máximo Subsuperficial de Clorofila de águas oceânicas, com máximos de abundância de $20 \times 10^{3}$ células. $\mathrm{mL}^{-1}$ e $5 \times 10^{3}$ células. $\mathrm{mL}^{-1}$, respectivamente. A biomassa heterotrófica bacteriana variou entre $4 \mu \mathrm{gC} . \mathrm{L}^{-1}$ a $30 \mu \mathrm{gC} . \mathrm{L}^{-1}$, com alta importância relativa, contribuindo em média para $67 \%$ da biomassa total. Prochlorococcus contribuiu com até $87 \%\left(8,2 \mu \mathrm{gC} . \mathrm{L}^{-1}\right)$ da biomassa picoplanctônica na Água Tropical. A contribuição de Synechococcus foi alta principalmente na Água Costeira e em águas de plataforma (22\% em média, máximo de $\left.21 \mu \mathrm{gC} . \mathrm{L}^{-1}\right)$. A dominância do picoplâncton mudou em direção ao sul, de Synechococcus para Prochlorococcus. A biomassa de picoeucariotos foi mais alta próxima ao Máximo Subsuperficial de Clorofila (máximo de $91 \%$ e $48 \mu \mathrm{gC} \cdot \mathrm{L}^{-1}$ ). A composição taxonômica do pico- e nanofitoplâncton foi determinada em três estações ao longo do gradiente trófico com auxílio do 16S rRNA plastidial, à partir de amostras selecionadas por citometria de fluxo. Os dados indicam que estas populações consistiram principalmente de Haptofíceas com sequências relacionadas ao hospedeiro de uma cianobactéria diazotrófica, UCYN-A, sugerindo uma alta importância desta simbiose na região estudada.

Palavras-chave: citometria de fluxo; sudoeste do Oceano Atlântico; picoplâncton, nanoplâncton, $16 S$ rRNA; Haptofíceas, UCYN-A. 


\section{ABSTRACT}

Primary production of the Southwest Atlantic Ocean (SAO, below $20^{\circ} \mathrm{S}$ ) is mainly influenced by the seasonal intrusion of the nutrient-rich South Atlantic Central Water (SACW) along the bottom of the continental shelf. To assess how this process affects pico- and nanoplankton communities, we determined by flow cytometry the abundance of heterotrophic bacteria, Prochlorococcus, Synechococcus, picoeukaryotes, and nanoeukaryotes in three transects along the Brazilian Bight, covering from $23^{\circ} \mathrm{S}$ to $31^{\circ} \mathrm{S}$ and $39^{\circ} \mathrm{W}$ to $49^{\circ} \mathrm{W}$. Heterotrophic bacteria and Prochlorococcus populations were abundant in Coastal and Tropical Waters, reaching $1.4 \times 10^{6}$ cells. $\mathrm{mL}^{-1}$, and $0.3 \times 10^{6}$ cells. $\mathrm{mL}^{-1}$, respectively. Synechococcus highest abundances $\left(81 \times 10^{3}\right.$ cells. $\mathrm{mL}^{-}$ $\left.{ }^{1}\right)$ were found mostly in superficial, shelf waters. Pico- and nanoeukaryotic cells were particularly important in Deep Chlorophyll Maximum layers from offshore waters, and their highest abundances were $20 \times 10^{3}$ cells. $\mathrm{mL}^{-1}$ and $5 \times 10^{3}$ cells. $\mathrm{mL}^{-1}$, respectively. The heterotrophic bacterial biomass ranged from $4 \mu \mathrm{gC} . \mathrm{L}^{-1}$ to $30 \mu \mathrm{gC} . \mathrm{L}^{-1}$, with high average relative importance (contributing on average to $67 \%$ of total biomass). With respect to total pico-phytoplanktonic biomass, Prochlorococcus contributed up to $87 \%$ $\left(8.2 \mu \mathrm{gC} . \mathrm{L}^{-1}\right)$ in Tropical Water. Synechococcus contribution was high mainly in Coastal Water and shelf waters (22\% on average, maximum of $\left.21 \mu \mathrm{gC} . \mathrm{L}^{-1}\right)$. Picoplankton structure shifted southwards from Synechococcus to Prochlorococcus dominance. Picoeukaryote biomass was higher near the DCM (maximum of $91 \%$ and $48 \mu \mathrm{gC} . \mathrm{L}^{-1}$ ). We determined the taxonomic composition of pico- and nanoeukaryote phytoplankton communities at 3 stations along the trophic gradient using the plastid16S rRNA gene from flow cytometry sorted cells. The data indicate that these populations consist mainly of Haptophyta with sequences related to the host of the diazotrophic cyanobacterium, UCYN-A, suggesting a high importance of this symbiosis in the region.

Keywords: flow cytometry; Southwest Atlantic Ocean; picoplankton; nanoplankton; $16 S$ rRNA; Haptophyta, UCYN-A. 


\subsection{INTRODUCTION}

The microbial communities of Southwest Atlantic Ocean (SAO), one of the largest biomes on earth, are just beginning to be unraveled (ALVES JUNIOR et al., 2015; BUITENHUIS et al., 2012). A complex system of layered water masses structures the primary productivity along the SAO. The South Atlantic Central Water (SACW) has an oceanic origin and is situated below the Tropical Water (TW), being characterized by uniform properties. Temperature/Salinity (T-S) diagram of the SACW is represented by a straight line between T- 5ㄷ / S - 34.3 psu and T- 20ㄷ / S - 36 psu (STRAMMA; ENGLAND, 1999; SVERDRUP; JOHNSON; FLEMING, 1942) (Figure S1). The SAO western boundary (below $20^{\circ} \mathrm{S}$ ) is mainly influenced by a wind-driven system, the seasonal intrusion of the nutrient-rich SACW along the bottom of the continental shelf (CAMPOS; VELHOTE; DA SILVEIRA, 2000; CASTRO et al., 2006) (Figure S2), which promotes euphotic layer fertilization (BRANDINI, 1990a), a shift from regenerated to new production (METZLER et al., 1997) and an influence on the structure of phytoplankton communities (MOSER et al., 2014; PEREIRA BRANDINI et al., 2014; SUSINI-RIBEIRO et al., 2013). The SACW intrusion takes place during the austral summer due to the action of the northeast wind, which induces offshore transport of surface waters by Ekman drift (CAMPOS; VELHOTE; DA SILVEIRA, 2000). SACW can also be pumped by cyclonic meanders of the Brazil Current $(\mathrm{BC})$, which consists of rotating domes of upwelled, cold water that flows inshore through the shelf break (CAMPOS; VELHOTE; DA SILVEIRA, 2000). The BC is a shallow current (ca 
$200 \mathrm{~m}$ ) restricted to the shelf break that flows southwestward to the Subtropical Convergence (33-38ㅇ), and transports the warm $\left(\mathrm{T}>20^{\circ} \mathrm{C}\right)$, salty $(\mathrm{S}>36 \mathrm{psu})$ and nutrient-poor Tropical Water (TW) (EMÍLSSON, 1961). The Coastal Water (CW) originates through characteristic processes of the inner portions of continental shelves, such as fresh water discharges and estuarine plumes, and its main features are low salinity ( $<<35 \mathrm{psu}$ ) and high spatial and seasonal variability (CASTRO et al., 2006).

Although the oligotrophic TW dominates the SAO euphotic zone, its production rate is higher than in subtropical gyres (BRANDINI, 1990b). Diatoms, dinoflagellates, coccolithophorids and cyanobacteria are amongst the most abundant groups in the region (BRANDINI, 1990a; FERNANDES; BRANDINI, 2004; MOSER et al., 2014; PEREIRA BRANDINI et al., 2014; SUSINI-RIBEIRO et al., 2013; VILLAC; CABRAL-NORONHA; PINTO, 2008). A few studies examined the influence of different water masses on the micro-phytoplankton composition (MOSER et al., 2014; PEREIRA BRANDINI et al., 2014) and the primary production in this region (BRANDINI, 1990a, 1990b). Although previous studies suggested a high importance of picoplankton, which may account for up to $64 \%$ of the total carbon biomass (SUSINI-RIBEIRO, 1999), little is known about the picophytoplankton abundance, diversity and response to the hydrodynamic regime in the SAO off Brazil.

In this study we used flow cytometry (FCM) to determine pico- and nanoplankton distributions and carbon standing stocks in the SAO off Brazil and assess their relationship to water masses. 


\subsection{OBJECTIVES}

(A) To determine pico- and nanoplankton (heterotrophic bacteria, Prochlorococcus, Synechococcus, pico- and nanoeukaryotes) distributions by flow cytometry, as well as their contribution to carbon biomass in the South Atlantic Ocean off Brazil.

(B) To investigate whether and how pico- and nanoplankton dominance patterns are influenced by the hydrodynamic regime of the water masses in the region.

(C) To perform an initial prospect of pico- and nanoplankton diversity with a small 16S rRNA clone library. 


\subsection{MATERIALS AND METHODS}

\subsubsection{Sampling}

Seawater samples were collected in the Southwest Atlantic off Brazil onboard the R/V "Alpha Crucis", between October and November of 2013. The surveyed area lies between Lat $23^{\circ} 11^{\prime} \mathrm{S}-30^{\circ} 52^{\prime} \mathrm{S}$ and Long $39^{\circ} 22^{\prime \prime} \mathrm{W}$ $49^{\circ} 09^{\prime \prime} \mathrm{W}$, extending to the 3510 meters isobath, along 2 transects (TR1 and TR2), comprising 5 depths per profile within the euphotic zone, and a third auxiliary transect, with only surface samples, called TR3 (Figure 1.1). A Trichodesmium spp. bloom was observed during TR2, for which additional sampling was performed at the surface (Station TRICHO). All samples were collected with $12 \mathrm{~L}$ Niskin bottles attached to a Seabird CTD-rosette system, except for surface samples from TR3 and TRICHO, which were collected with a polycarbonate bucket. The temperature vs salinity data from CTD were used to identify the water masses distribution in the transects. Duplicate samples $(1.5 \mathrm{~mL})$ for flow cytometry were put into cryotubes, preserved with $0.1 \%$ glutaraldehyde (final concentration), flash-frozen in liquid nitrogen and stored at $-80^{\circ} \mathrm{C}$ until analysis. Samples for FCM sorting $(1.5 \mathrm{~mL})$ were preserved with 10\% DMSO (final concentration) and proceed as described above. 


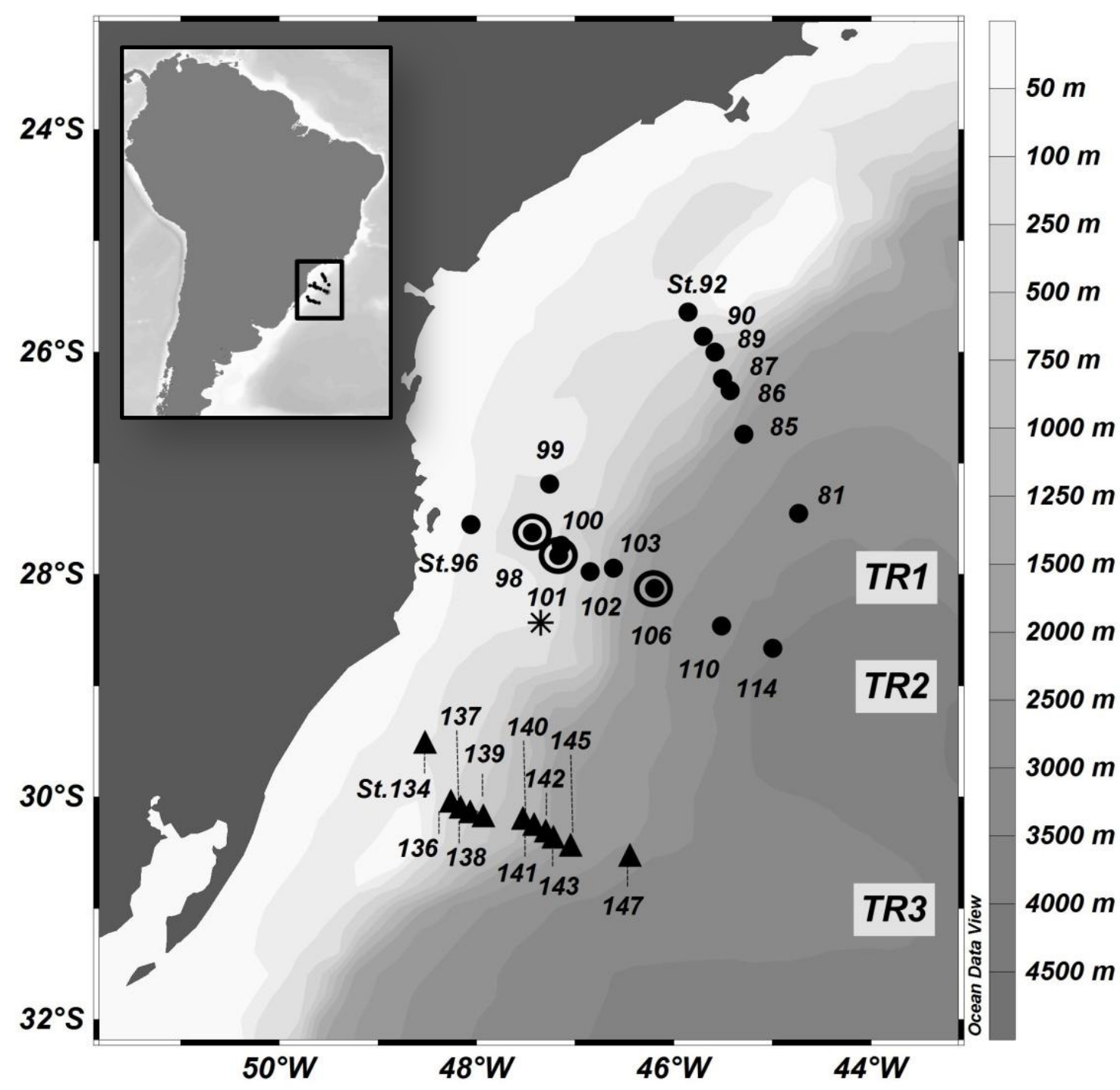

Figure 1.1. Location of sampling stations in the SAO off Brazil (11-18 November 2013). Profiles: transect 1 (TR1, St.81 to 92) and transect 2 (TR2, St.96 to 114), represented by black dots; Surface sampling: transect 3 (TR3, St.133 to 147), represented by black triangles. Sampling stations where 16S rRNA partial sequences were retrieved are marked with a circle. The asterisk represent the TRICHO station, inside a Trichodesmium spp. bloom. 


\subsubsection{Flow Cytometry Analysis}

We performed flow cytometry analysis using a BD FACSCanto ${ }^{\mathrm{TM}}$ (Becton

Dickinson, San Jose, CA) flow cytometer equipped with a blue laser (488 nm, air-cooled, $20 \mathrm{~mW}$, solid state). Samples were thawed at room temperature, and $0.95 \mu \mathrm{m}$ beads were used for calibration. In order to visualize heterotrophic prokaryotes (BACT) we added SYBR Green ${ }^{\circledR}$ dye (1:10000, final concentration) (Molecular Probes, Leiden, Netherlands) and used the following settings: medium sample rate, limit of $60 \mu \mathrm{L}$ and threshold of 700 on FL1-H (SYBR fluorescence). For natural fluorescence we used the following parameters: fast sample rate, limit of $200 \mu \mathrm{L}$ and threshold of 700 on FL3-H (chlorophyll fluorescence). The parameters chlorophyll and phycoerythrin fluorescence, forward and side scatter were used to distinguish between four major groups: PRO (Prochlorococcus), SYN (Synechococcus), PEUK (picoeukaryotes) and NEUK (nanoeukaryotes). FCM data were analyzed in the Flowing Software ${ }^{\circledR} 2.5$ (http://www.flowingsoftware.com). For the purpose of this study, the prokaryotic organisms (which may include Bacteria and Archaea) will be herein referred to as 'bacteria'.

Picoplankton biomass (BACT, PRO, SYN and PEUK) was calculated from the abundance data generated by flow cytometry, using the volume-carbon conversion factorsfrom the literature for heterotrophic bacteria (20 fgC.cell ${ }^{-1}$ ) (LEE; FUHRMAN, 1987), and for Prochlorococcus (36 fgC.cell ${ }^{-1}$ ), Synechococcus (255 fgC.cell $\left.{ }^{-1}\right)$, and picoeukaryotes (2590 fgC. cell $\left.{ }^{-1}\right)$ (BUITENHUIS et al., 2012).Nanophytoplanktonic biomass was not calculated due the lack of robust conversion factors to carbon content. Statistical analyzes were made in the software STATISTICA $12.5^{\circledR}$. 


\subsubsection{Clone libraries}

We performed a small clone library of the plastid 16S rRNA gene of phytoplanktonic eukaryotes from sorted surface samples from 3 stations along TR2, corresponding to 3 regions along the trophic gradient. Samples were sorted with FACSAria ${ }^{\mathrm{TM}}$ flow cytometer (Becton Dickinson, San Jose, CA, USA) equipped with $488 \mathrm{~nm}$ laser and $70 \mu \mathrm{m}$ nozzle. The emitted light was collected through the following filter set: $488 / 10$ band pass (BP) for side scatter, 576/26 (BP) for orange fluorescence, and 655 long pass (LP) for red fluorescence. Pico- and nanoeukaryotes were selected using light scattering, orange (phycoerythrin) and red fluorescence emission (chlorophyll). Sorting was performed at a droplet frequency of $90,000 \mathrm{~Hz}$, with a deflection voltage of 6,000 V. Cell populations were collected in Eppendorf tubes prefilled with 100 $\mu \mathrm{L}$ of Tris $(10 \mathrm{mM}) / \mathrm{EDTA}(1 \mathrm{mM}) /$ Triton $(1.2 \%$, final concentration) solution sterilized through $0.2 \mu \mathrm{M}$ filter. Prior to amplification, collected cells were subjected to a cycle of thawing and freezing in liquid nitrogen. The 16S rRNA plastidial gene was amplified using PLA491F (5'-GAG GAA TAA GCA TCG GCT AA-3') and OXY1313R (5'-CTT CAY GYA GGC GAG TTG CAG C-3') (FULLER et al., 2003, 2006; SHI et al., 2011). PCR amplifications were performed with $5 \mu \mathrm{L}$ of sorted cell sample, 2X Phusion ${ }^{\circledR}$ High-Fidelity PCR Master Mix $(10 \mu \mathrm{L})$ (Thermo Fisher Scientific, Waltham, MA, USA), $4 \mathrm{mM}$ of each primer, DMSO (3\%, final concentration) and water, to a final volume of 20 $\mu$ l. PCR conditions were: $95^{\circ} \mathrm{C}$ for $5 \mathrm{~min}$, followed by 35 cycles of $95^{\circ} \mathrm{C}$ for $30 \mathrm{~s}$, $60^{\circ} \mathrm{C}$ for $30 \mathrm{~s}, 72^{\circ} \mathrm{C}$ for $2 \mathrm{~min}$, and a final cycle of $72^{\circ} \mathrm{C}$ for $10 \mathrm{~min}$. PCR products were purified with the NucleoSpin ${ }^{\circledR}$ Gel and PCR Clean-up kit (MACHEREY-NAGEL, Düren, Germany), following manufacturer's instructions. 
Poly-A tails were added with GoTaq ${ }^{\circledR}$ Flexi DNA Polymerase (Promega, Madison, WI, USA). The reaction (27.05 $\mu$, final volume) comprised: $3.5 \mathrm{x}$ Colorless GoTaq ${ }^{\circledR}$ Flexi Buffer (5x), $5.3 \mathrm{mM} \mathrm{MgCl}_{2}, 0.7 \mathrm{mM}$ dATP, $0.25 \mathrm{U}$ GoTaq $^{\circledR}$ DNA Polymerase $(5 \mathrm{U} / \mu \mathrm{l})$ and $20 \mu \mathrm{l}$ of PCR product. The reaction was incubated at $72^{\circ} \mathrm{C}$ for 10 minutes in a thermocycler. Products were cloned into the vector with the TOPO TA Cloning ${ }^{\circledR}$ kit (Invitrogen, Carlsbad, CA, USA), according to manufacturer's instructions, and transformed by heat-shock in Ecoli One Shot ${ }^{\circledR}$ TOPO10 competent cells. Positive clones were amplified with the primers and conditions described above, purified and sent to sequencing in a MACROGEN facility (Amsterdam, Netherlands). Sequences were compared with public databases using NCBI BLAST web application and grouped into distinct operational taxonomic units (OTUs) with $98 \%$ similarity using MOTHUR (SCHLOSS et al., 2009). One representative sequence from each OTU was used to phylogenetic analysis and deposited in the GenBank database under accession numbers KU059496-KU059501. Sequences from this study and related sequences recovered from public databases were aligned with MUSCLE alignment in Geneious ${ }^{\circledR}$ R9 software (KEARSE et al., 2012). The alignment was analyzed by Maximum Likelihood using PhyML pluggin (GUINDON et al., 2010) in Geneious ${ }^{\circledR}$ R9, TN93 (Tamura-Nei) as model of nucleotides substitution, and bootstrap values estimated from 1,000 replicates. 


\subsection{RESULTS}

\subsubsection{Environmental conditions}

The three main SAO epipelagic water masses were sampled in this study: Coastal Water (TR2, TR3), Tropical Water (TR1, TR2, TR3) and South Atlantic Central Water (TR1, TR2). The upward displacement of the thermocline and SACW cold water's intrusion, as well as a minor SACW elevation in the outermost stations were observed in both TR1 and TR2 (Figure 1.2 and 1.3).

Temperature variation was more abrupt and with a wider cross-shelf range in $\mathrm{TR} 1$ (from $12.8^{\circ} \mathrm{C}$ to $23.8^{\circ} \mathrm{C}$ ) than in $\mathrm{TR} 2$ (from $13.9^{\circ} \mathrm{C}$ to $23.8^{\circ} \mathrm{C}$ ), but salinity variation was considerably milder, ranging from $35.1-36.8$ on TR1 and from 33.4 - 37.2 in TR2. Tropical Water along the surface mixed layer in TR2 was saltier and slightly warmer than in TR1 (Figure 1.2). For the surface transect $\mathrm{TR} 3$, temperature ranged from $20.2^{\circ} \mathrm{C}$ to $23^{\circ} \mathrm{C}$, while salinity range was wider (from 33.5 to 36.8 ), indicating the presence of $\mathrm{CW}$ at inner stations (Figure 1.5 - A, B).

The rise of the thermocline over the continental slope induced both upward displacement and enhancement of the DCM (Figure 1.3 - A, C). Chlorophyll fluorescence ranged from 2.7 to 780 RFU (Relative Fluorescence Unit), with medium values of 191 and 187 RFU in TR1 and TR2, respectively. A DCM was present at all stations along TR1 and TR2, with an obvious enhancement due thermocline upward displacement (Figure 1.3 - A, C), of up 
to 50 meters in TR1. In TR3, fluorescence ranged from 17 to 210 RFU (Figure $1.5-C)$.

The nutricline is sharply defined in TR1 and TR2, more or less coincident with the SACW upper limit (Figure 1.3 - B, D and $1.4-$ A, B). Local concentration maxima were observed near the continental shelf bottom (8.7 $\mu \mathrm{M} . \mathrm{L}^{-1}$ and $9.1 \mu \mathrm{M} . \mathrm{L}^{-1}$ of nitrates, $1 \mu \mathrm{M} . \mathrm{L}^{-1}$, and $1.1 \mu \mathrm{M} . \mathrm{L}^{-1}$ of phosphates in TR1 and TR2, respectively). The sampling points where CW was observed were characterized by low nutrient concentration, except for a slightly increase in phosphates (up to $0.4 \mu \mathrm{M} . \mathrm{L}^{-1}$ ) while nitrates were close to depletion in all surface samples (Figure 1.3 - B, D and 1.4 - A, B). 
TR1
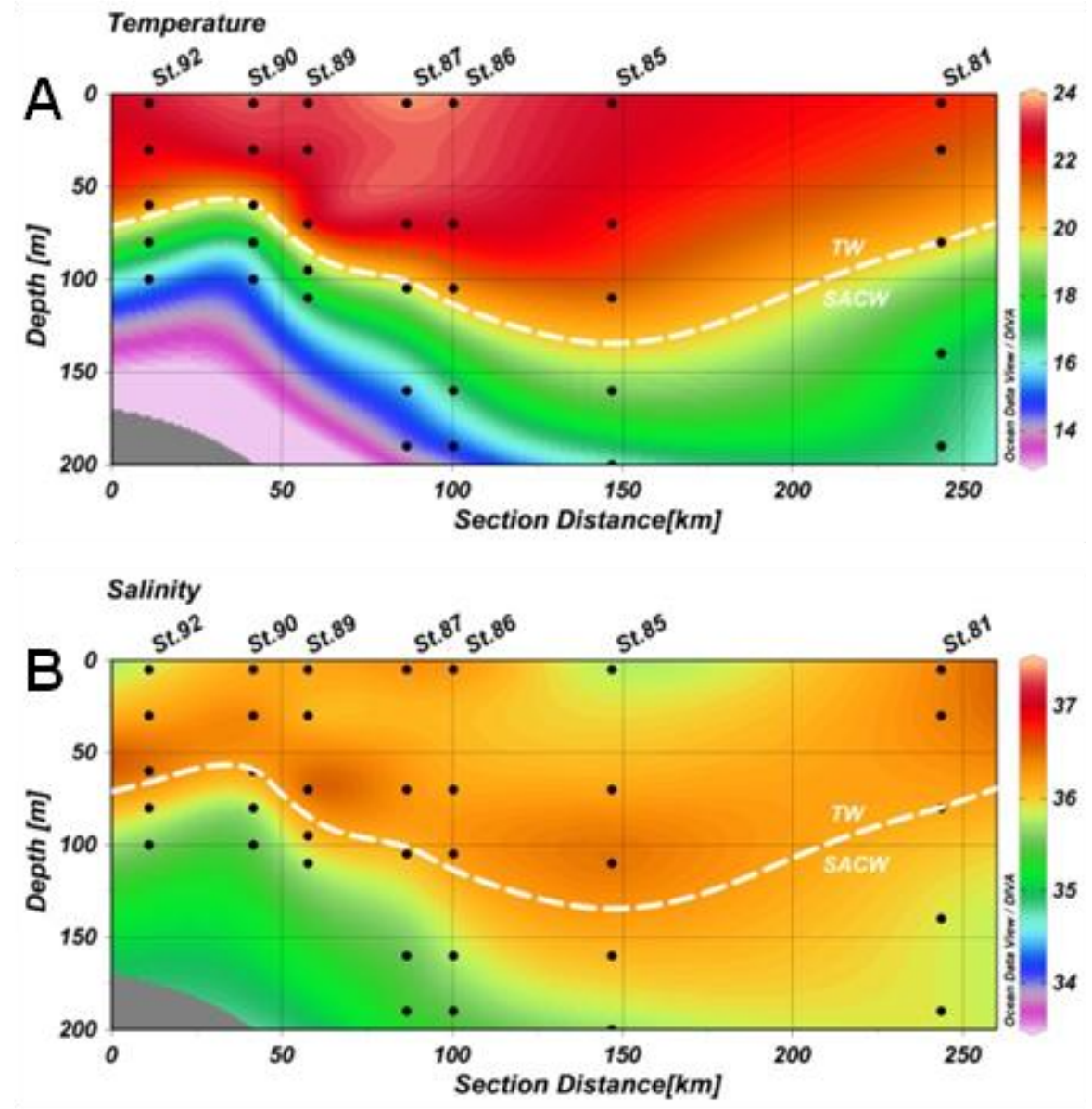

TR2
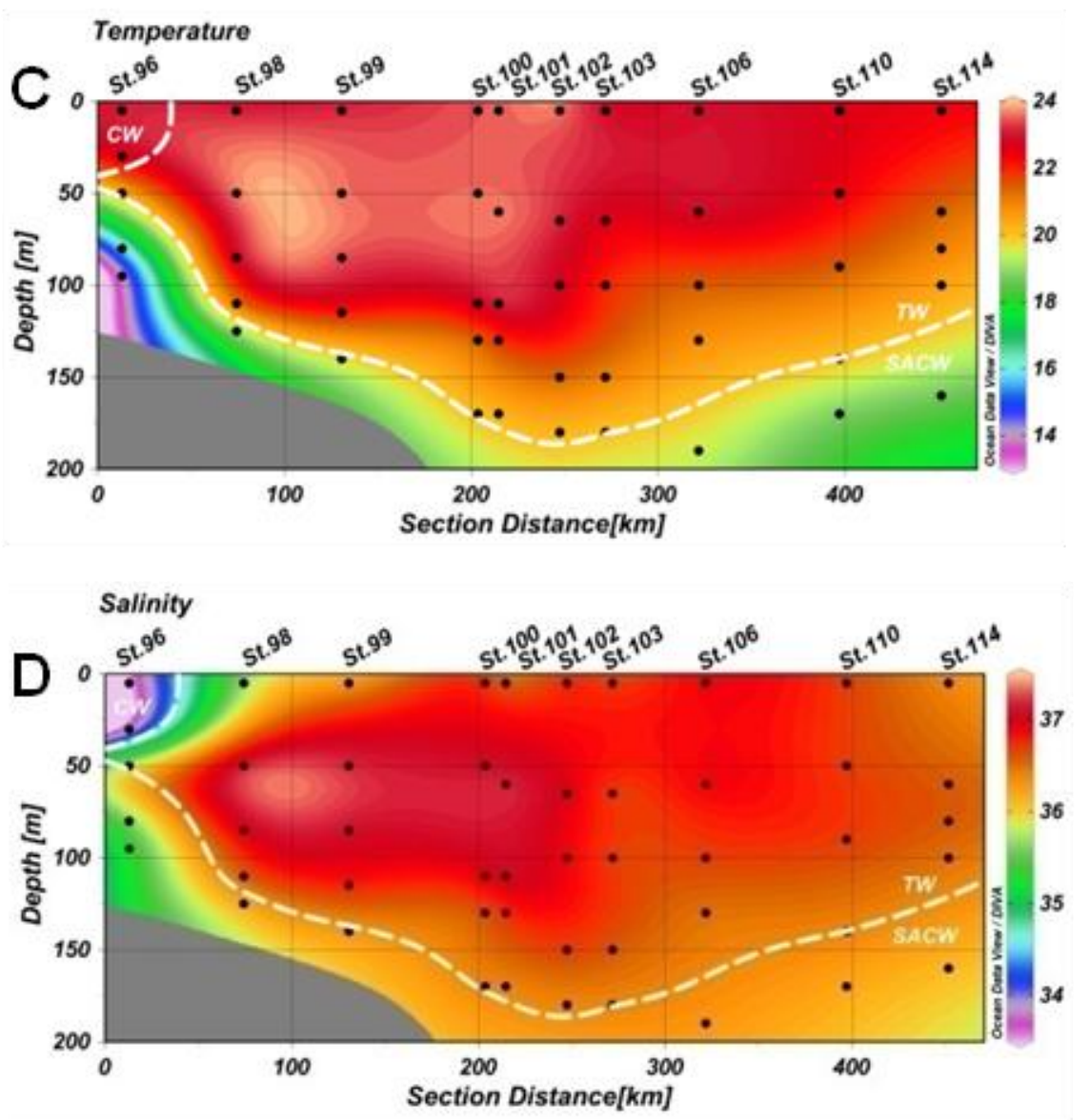

Figure 1.2. Vertical distribution of temperature $\left(\mathrm{T}^{\circ} \mathrm{C}\right)$ and salinity, for transect $1(\mathbf{A}, \mathbf{B})$ and transect $2(\mathbf{C}$, D); numbers indicate sampling stations; black dots indicate sampling depths; water masses are delimitated in white: Tropical Water (TW); South Atlantic Central Water (SACW) and Coastal Water (CW). 


\section{TR1}
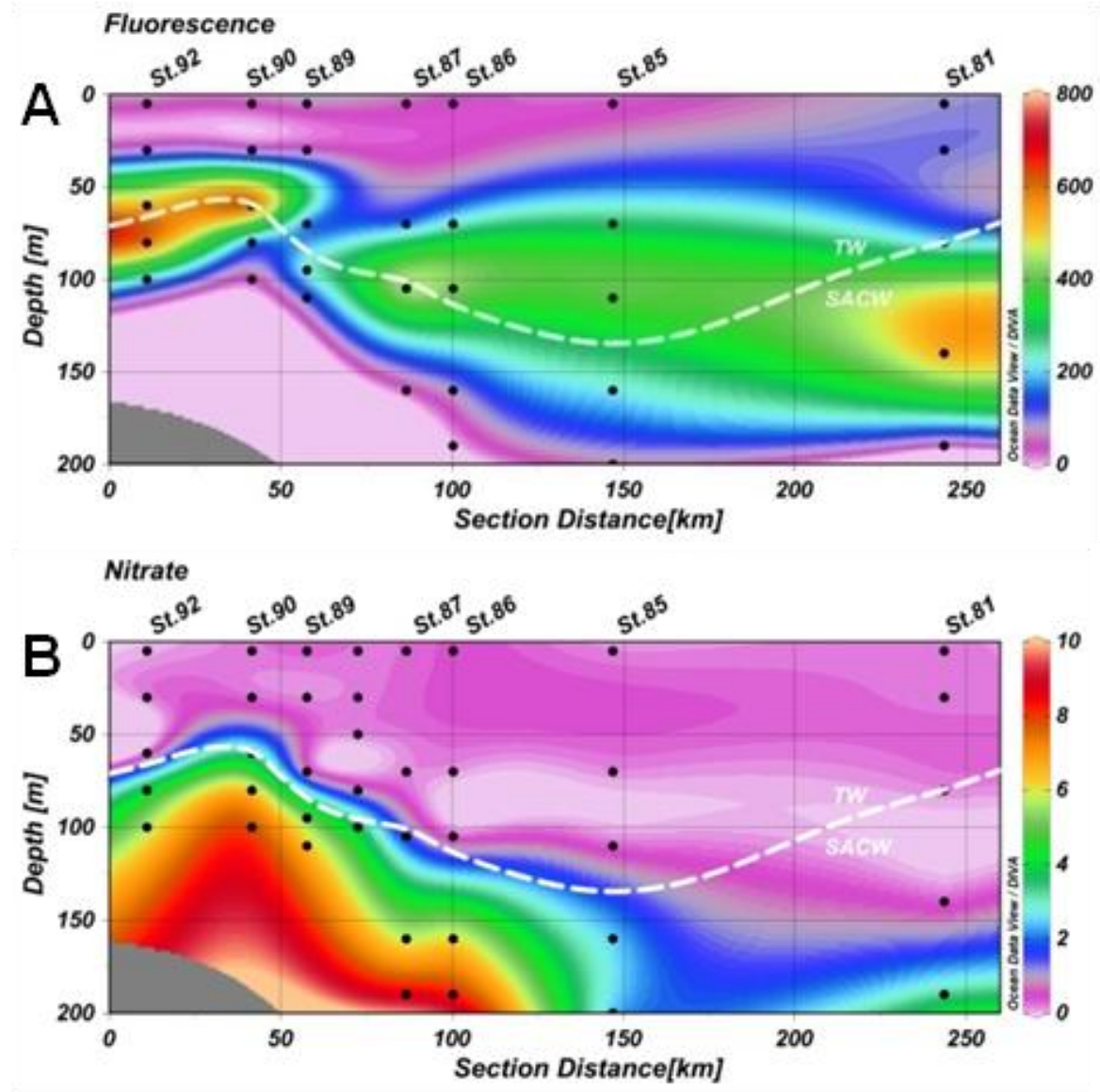

\section{TR2}
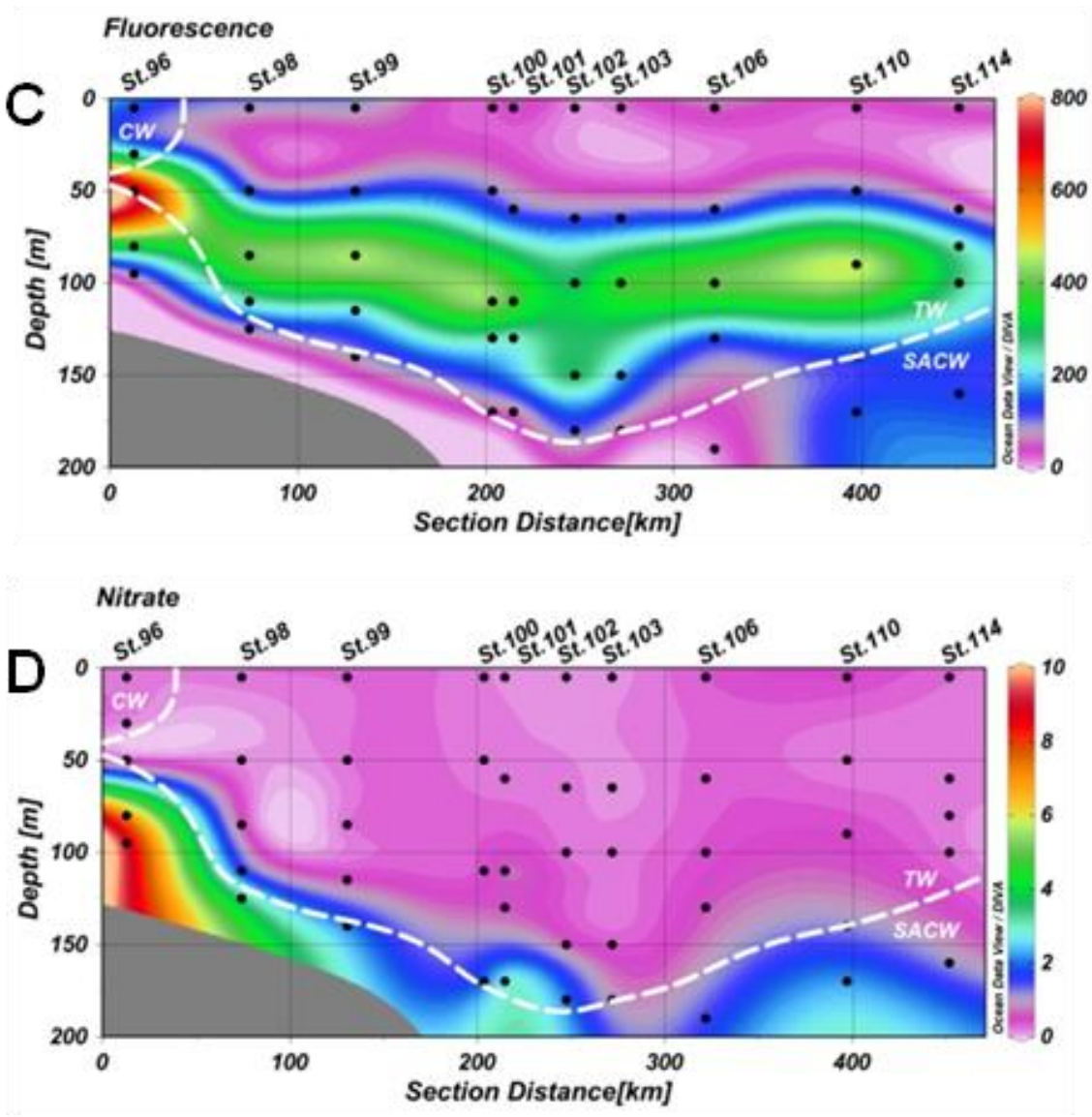

Figure 1.3. Vertical distribution of fluorescence (RFU) and nitrate $\left(\mu \mathrm{M} . \mathrm{L}^{-1}\right)$, for transect 1 (A, B) and transect $2(\mathbf{C}, \mathbf{D})$; numbers indicate sampling stations; black dots indicate sampling depths; water masses are delimitated in white: Tropical Water (TW); South Atlantic Central Water (SACW) and Coastal Water (CW). 
TR1

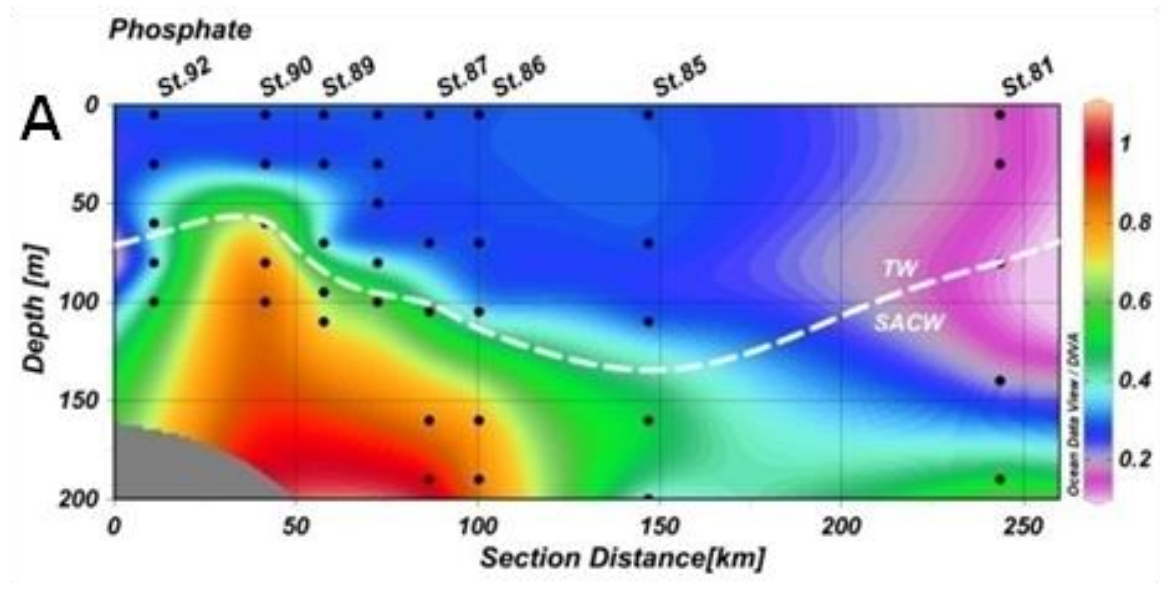

\section{TR2}

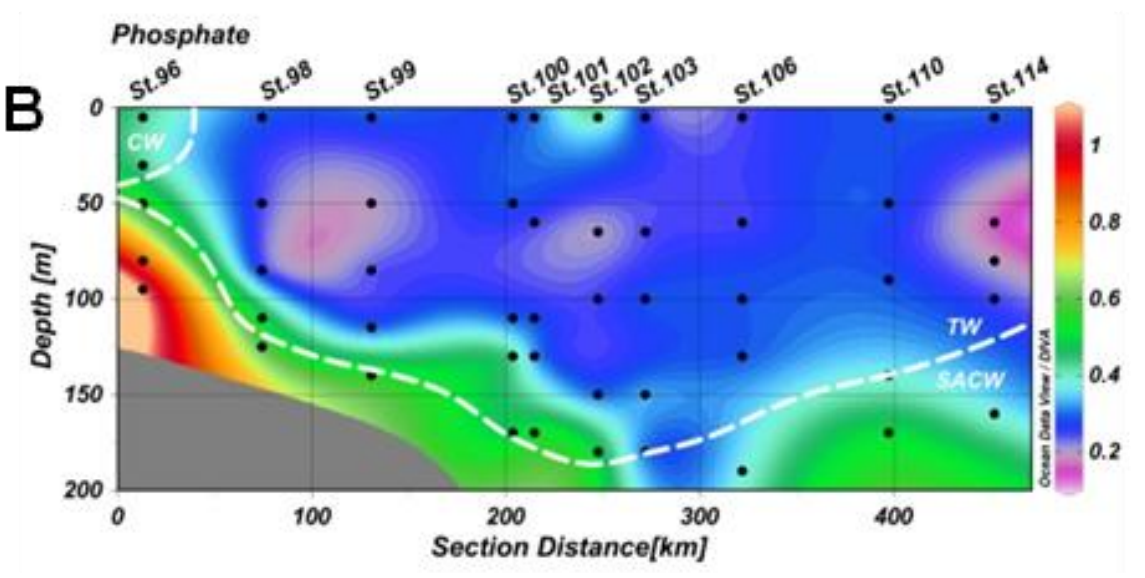

Figure 1.4. Vertical distributions of phosphates $\left(\mu \mathrm{M} . \mathrm{L}^{-1}\right)$, for transect $1(\mathbf{A})$ and transect $2(\mathbf{B})$; numbers indicate sampling stations; black dots indicate sampling depths; water masses are delimitated in white: Tropical Water (TW); South Atlantic Central Water (SACW) and Coastal Water (CW). 

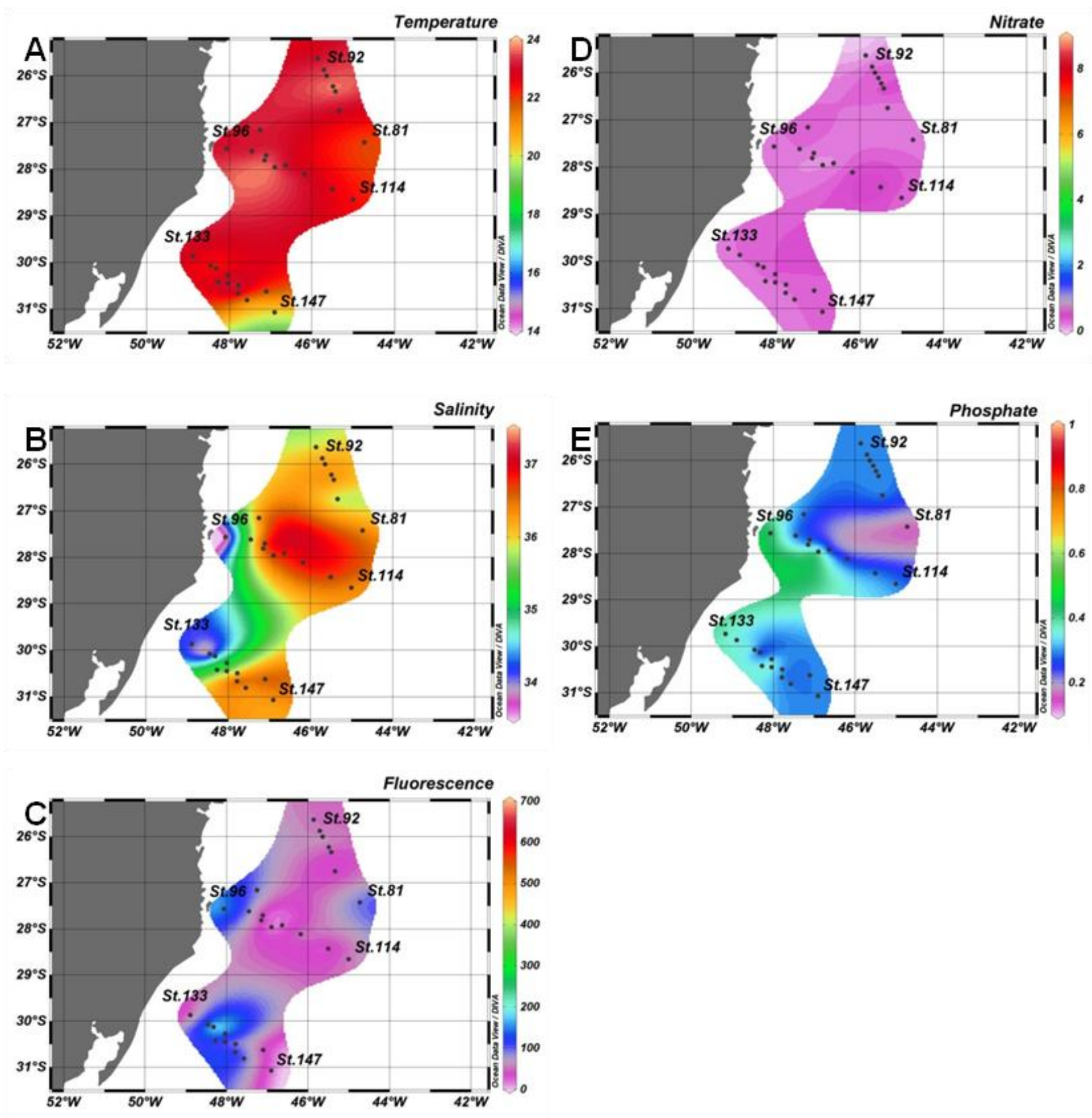

Figure 1.5. Surface distribution of temperature $\left(T^{\circ} \mathrm{C}\right)(\mathbf{A})$, salinity $(B)$, fluorescence (RFU) (C), nitrates $\left(\mu \mathrm{M} . \mathrm{L}^{-1}\right)(\mathrm{D})$ and phosphates $\left(\mu \mathrm{M} . \mathrm{L}^{-1}\right)(\mathrm{E})$ for transect 1,2 and 3; numbers indicate the beginning and the end of each transect; black dots indicate each station. 


\subsubsection{Abundance of microbe populations}

BACT populations were abundant in Coastal Water and throughout Tropical Water (Figure 1.6 - A, B). SACW intrusions and the raise of the thermocline increased BACT abundances near the shelf break in both transects, with maxima of $1.3 \times 10^{6}$ and $1.2 \times 10^{6}$ cells. $\mathrm{mL}^{-1}$ in TR1 and TR2, respectively. The innermost station of TR3 had the highest BACT abundance of the cruise $\left(1.5 \times 10^{6}\right.$ cells. $\left.\mathrm{mL}^{-1}\right)$ (Figure $\left.1.9-\mathrm{A}\right)$. Abundance maxima were found from the superficial layer down to 80 meters depth in TR1 $\left(1.1 \times 10^{6}\right.$ cells. $\left.\mathrm{mL}^{-1}\right)$ and 65 meters depth in TR2 $\left(1.2 \times 10^{6}\right.$ cells. $\left.\mathrm{mL}^{-1}\right)$. The presence of a Trichodesmium spp. bloom in TR2 caused a sharp increase in heterotrophic bacteria abundance $\left(3 \times 10^{6}\right.$ cells. $\left.\mathrm{mL}^{-1}\right)$ (more details in Chapter 2$)$.

PRO abundances were higher in CW and TW surface waters (Figure 1.6 - B, D). In TR1, higher PRO abundances were coincident with upward movements of SACW, reaching the lower limit of the DCM (Figure 1.6 - B), with high abundance maxima at its inner and outermost stations $\left(230 \times 10^{3}\right.$ and $261 \times 10^{3}$ cells. $\mathrm{mL}^{-1}$, respectively). PRO abundance was higher and its distribution was more stratified in TR2. In fact, its higher concentrations $\left(290 \times 10^{3}\right.$ cells. $\left.\mathrm{mL}^{-1}\right)$, were located immediately above downward oscillations of SACW. In TR2, the raise if the thermocline and presence of CW did not seem to influence PRO concentrations. PRO highest abundance in TR3 $\left(266 \times 10^{3}\right.$ cells. $\mathrm{mL}^{-1}$ ) was in the middle of the transect (Figure 1.9 - B).

SYN highest abundances were found in the surface layer. Concentrations were high throughout the TW in TR1 (Figure 1.7 - A). Maximum abundance $\left(81 \times 10^{3}\right.$ cells. $\left.\mathrm{mL}^{-1}\right)$ was found in surface at St. 92 which was the 
closest to the coast. In TR2, SYN highest concentration $\left(67 \times 10^{3}\right.$ cells. $\left.\mathrm{mL}^{-1}\right)$ were also found nearest to the coast, but at the thermocline raise, at 50 meter depth (Figure 1.7 - B). In TR2, in contrast to TR1, SYN distribution was more confined to the continental shelf (Figure 1.7 - B), especially in CW, and in the transition waters from CW to TW. In TR3, only sampled in surface, SYN maximum was also observed at the innermost station $\left(39 \times 10^{3}\right.$ cells. $\left.\mathrm{mL}^{-1}\right)$ (Figure 1.9 - C).

PEUK populations in TR1 were greatly enhanced by thermocline upward displacement, as can be observed in St. 92 of Figure 1.7 - B $\left(18 \times 10^{3}\right.$ cells.mL $\left.{ }^{1}\right)$. Two local abundance maxima are visible along the transect $\left(18 \times 10^{3}\right.$ and $4 \times 10^{3}$ cells. $\left.\mathrm{mL}^{-1}\right)$, descending along with SACW and coincident with the DCM. Lower abundance values were found in TR2 and no increase at inner stations was detected. TR2 abundance maxima $\left(3 \times 10^{3}, 4 \times 10^{3}\right.$ and $5 \times 10^{3}$ cells. $\left.\mathrm{mL}^{-1}\right)$ were spread out along the transect, near the DCM (Figure 1.7 - D). Low PEUK surface abundance was found in all profiles, as well as in TR3, for which maximum abundance was $2 \times 10^{3}$ cells. $\mathrm{mL}^{-1}$ at its innermost station (Figure 1.9 D).

NEUK distribution along TR1 was very similar to PEUK distribution at the inner stations of the transect, but beyond the shelf break their distribution was wider vertically, reaching both the surface layer and the lower limit of DCM. Maximum abundance was right above thermocline elevation $\left(5 \times 10^{3}\right.$ cells. $\left.\mathrm{mL}^{-1}\right)$ (Figure 1.8 - A). Just as PEUK, TR2 NEUK abundance distribution seem to have a close relationship with DCM along the transect, although an increase $\left(1.6 \times 10^{3}\right.$ cells. $\left.\mathrm{mL}^{-1}\right)$ could be observed in the CW/SACW intersection (St. 96, at 
50 meters depth) (Figure 1.8 - B). NEUK surface distribution was very patchy and ranged from 176 to $1.3 \times 10^{3}$ cells. $\mathrm{mL}^{-1}$ (Figure $1.9-\mathrm{E}$ ).

The first two components of a PCA based on temperature, salinity, nitrates and phosphates explained $93 \%$ of the observed variability (Figure $\mathbf{1 . 1 0}$ - A), The first axis was positively correlated with temperature and negatively with nutrients, which reflects the influence of cold nutrient rich SACW, while the second axis was positively correlated with salinity. PRO, NEUK and PEUK were correlated with the first axis while SYN and BACT appeared to be influenced by both axis. Samples from TR2 were much more grouped than TR1 (Figure 1.10 - B). TR2 samples were also influenced by their TW higher salinity. The only set of samples that had a widespread distribution originated from St. 96, the innermost station of TR2 (Figure 1.10). This station has the largest range of temperature/salinity, being located in the intersection of CW and SACW (Figure 1.2 - C, D). 
TR1
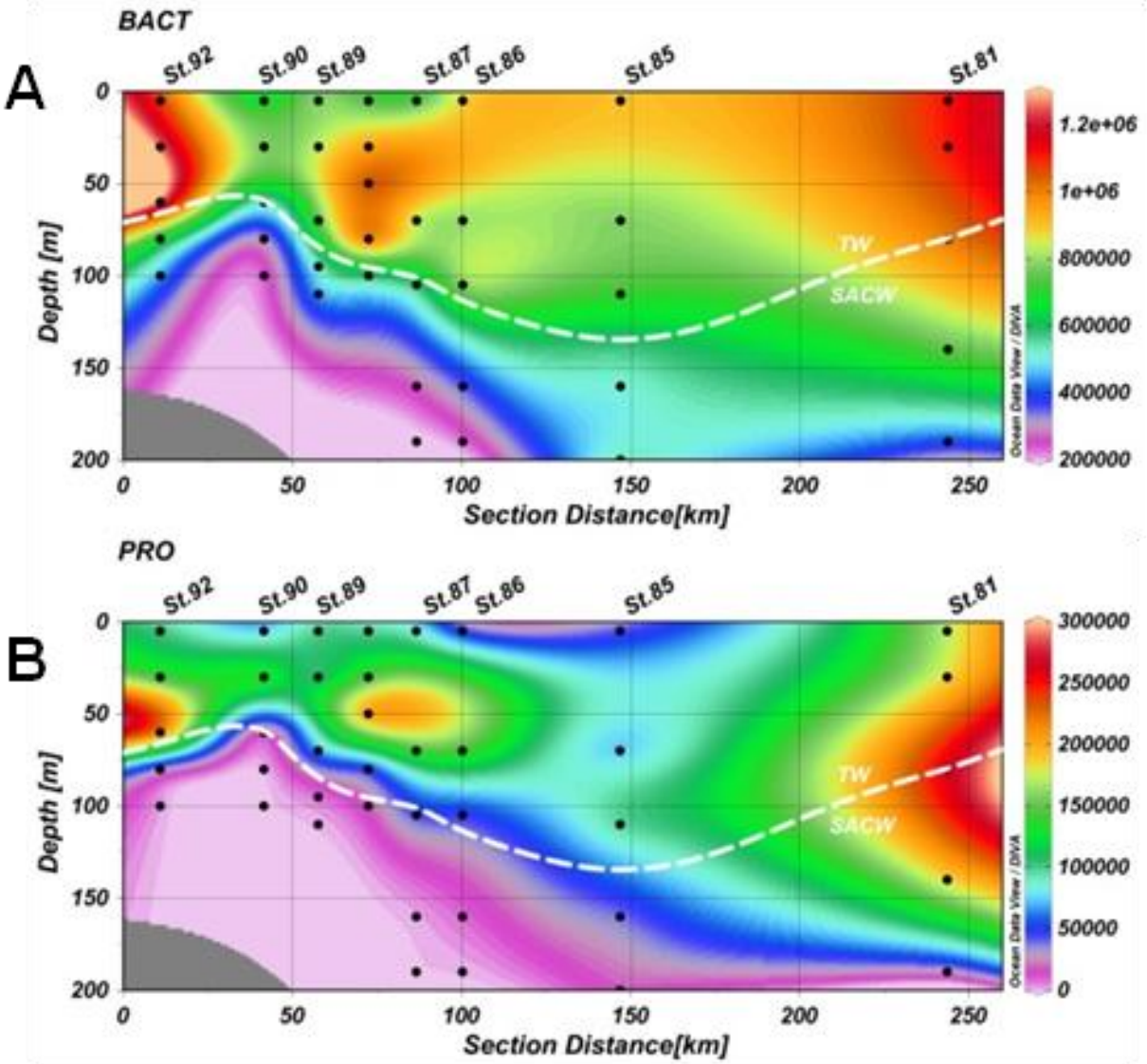

TR2
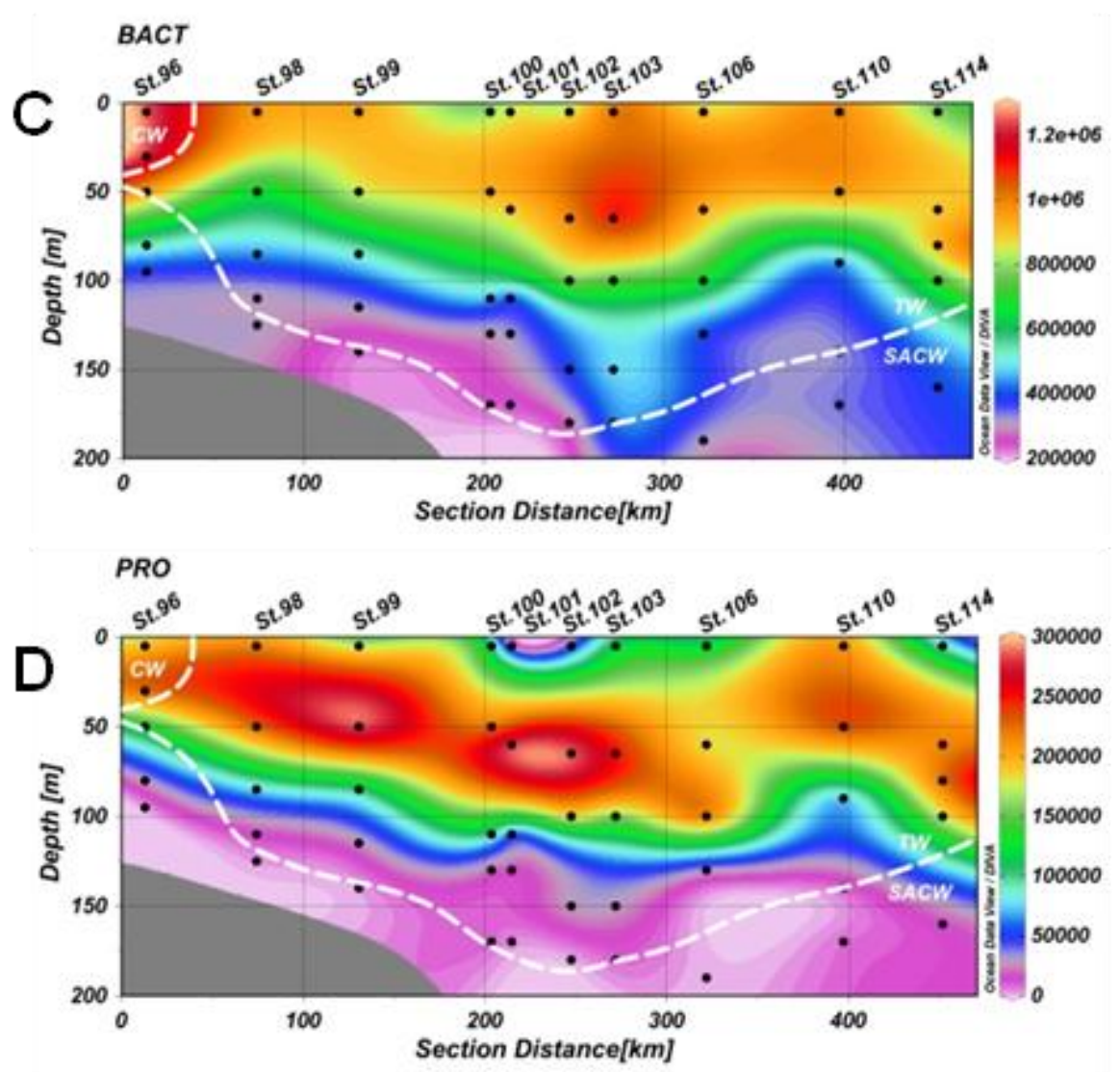

Figure 1.6. Vertical distribution of total heterotrophic bacteria and Prochlorococcus (in cells. $\mathrm{mL}^{-1}$ ), for transect 1 (A, B) and transect 2 (C, D); numbers indicate sampling stations; black dots indicate sampling depths; water masses are delimitated in white: Tropical Water (TW); South Atlantic Central Water (SACW) and Coastal Water (CW). 


\section{TR1}
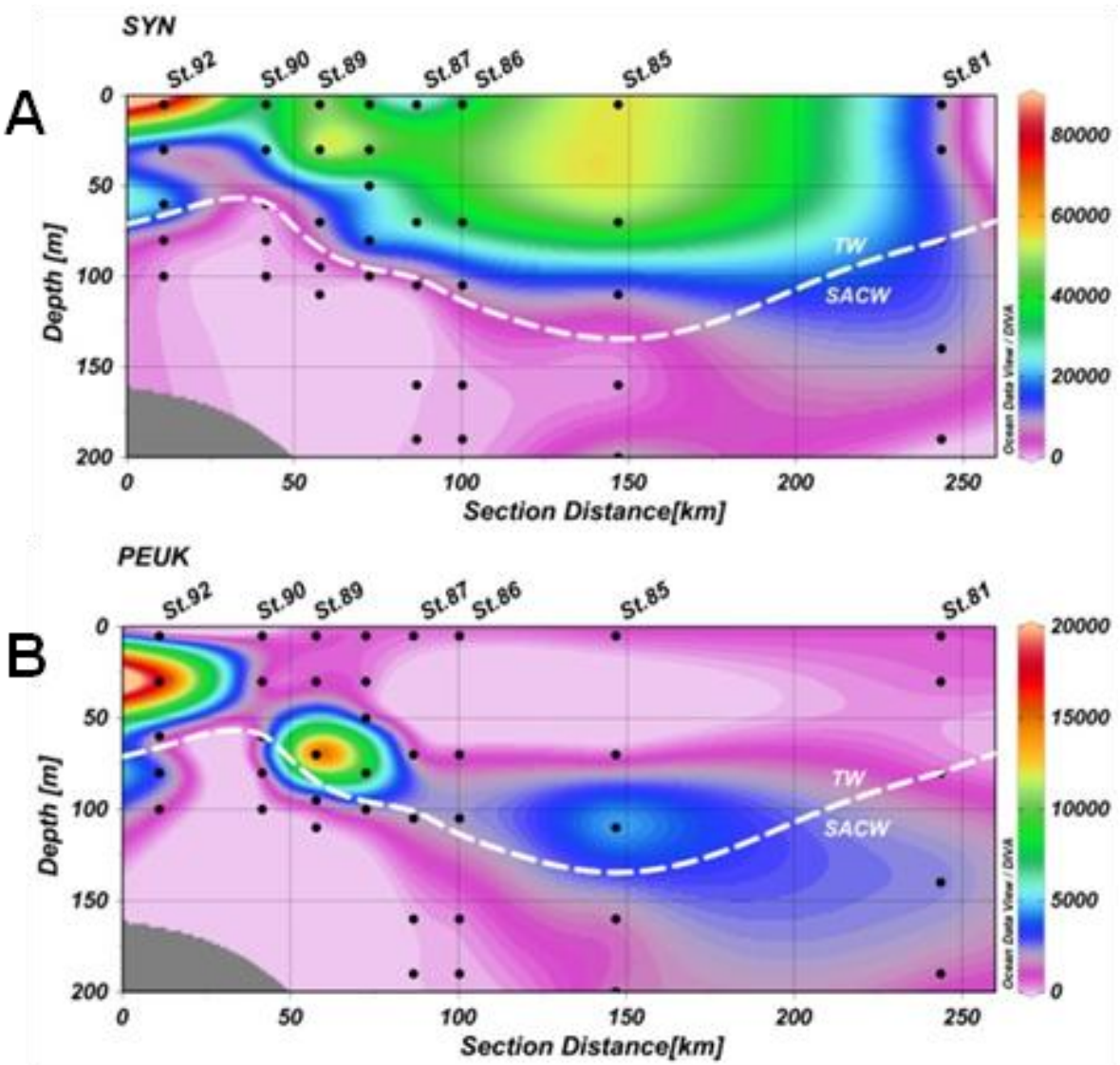

\section{TR2}
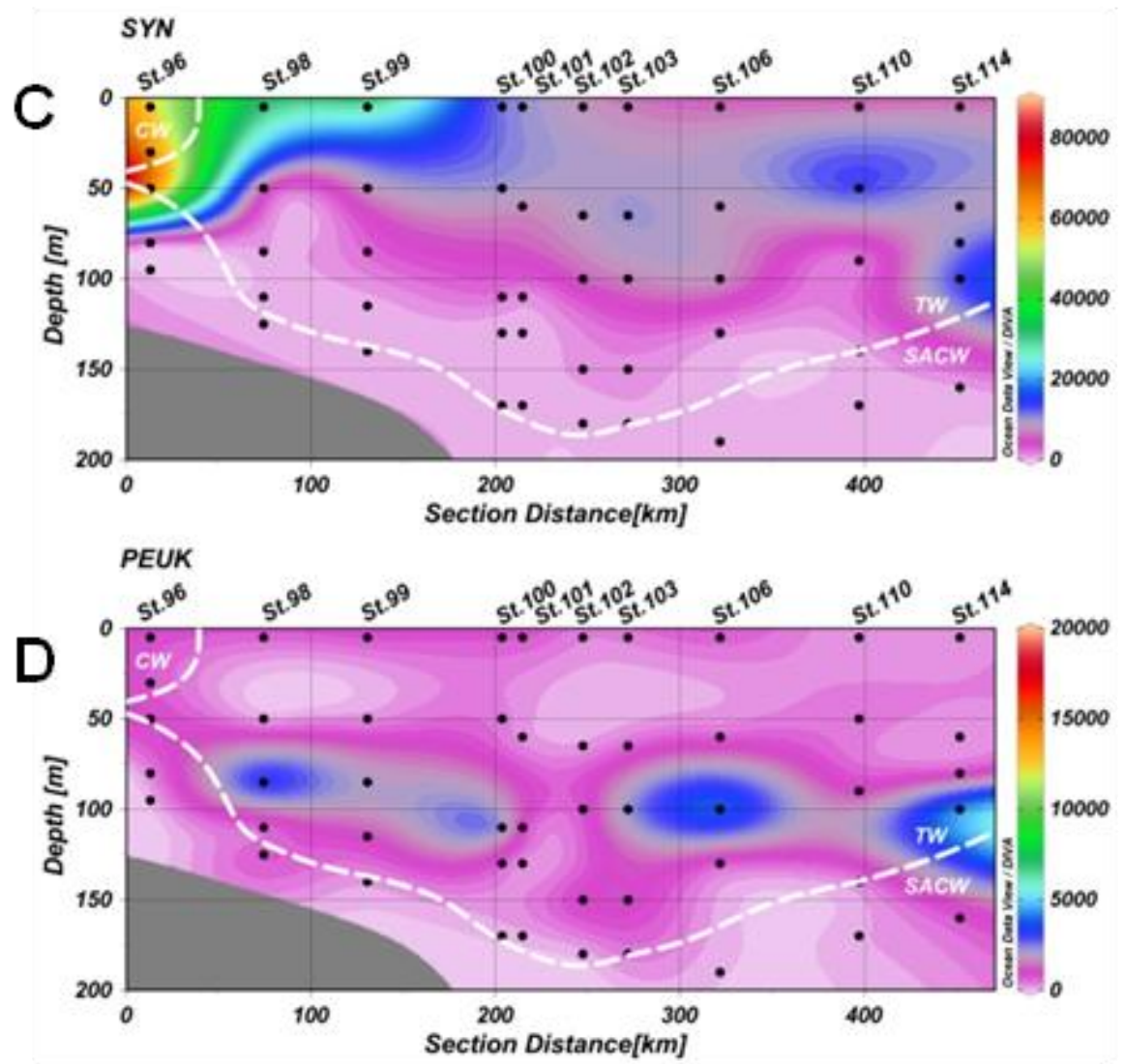

Figure 1.7. Vertical distribution of Synechococcus and picoeukaryotes (in cells. $\mathrm{mL}^{-1}$ ), for transect 1 (A, B) and transect 2 (C, D); numbers indicate sampling stations; black dots indicate sampling depths; water masses are delimitated in white: Tropical Water (TW); South Atlantic Central Water (SACW) and Coastal Water (CW). 


\section{TR1}

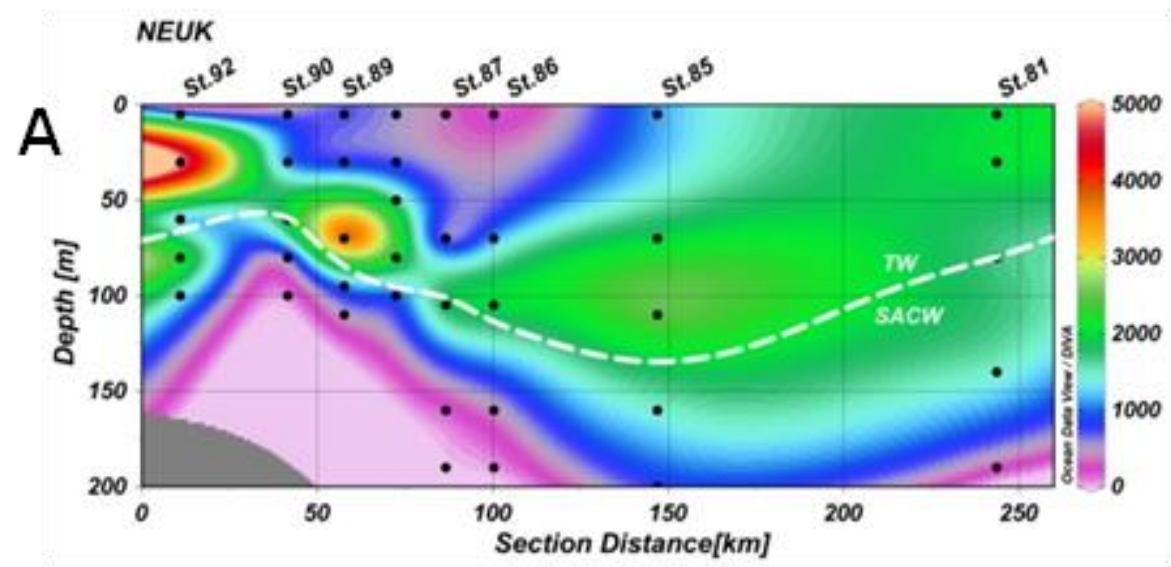

TR2

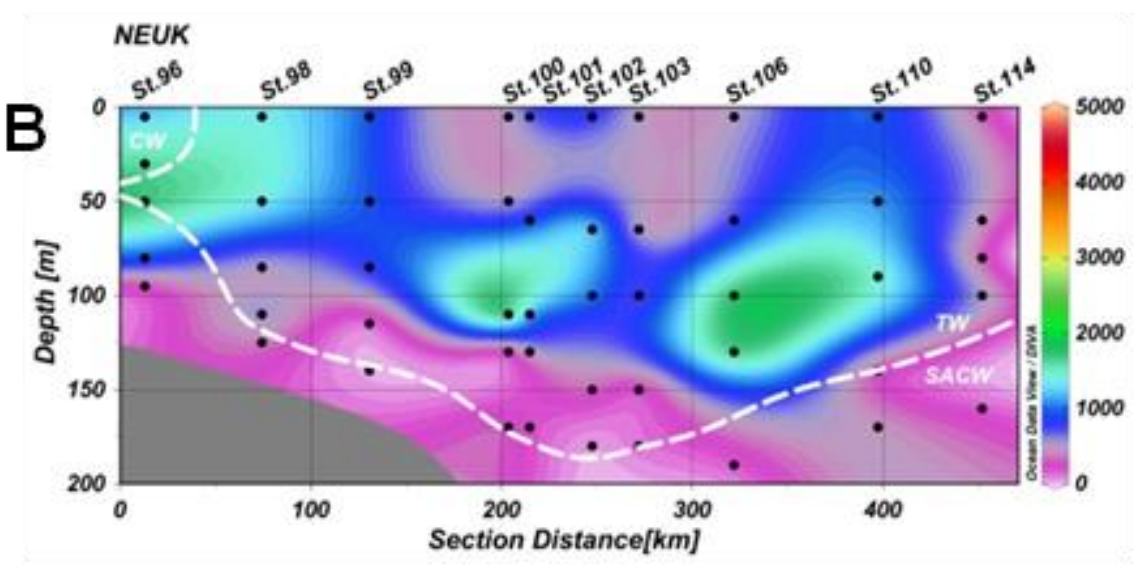

Figure 1.8. Vertical distribution of: nanoeukaryotes (in cells. $\mathrm{mL}^{-1}$ ), for transect 1 (A) and transect 2 (B); numbers indicate sampling stations; black dots indicate sampling depths; water masses are delimitated in white: Tropical Water (TW); South Atlantic Central Water (SACW) and Coastal Water (CW). 

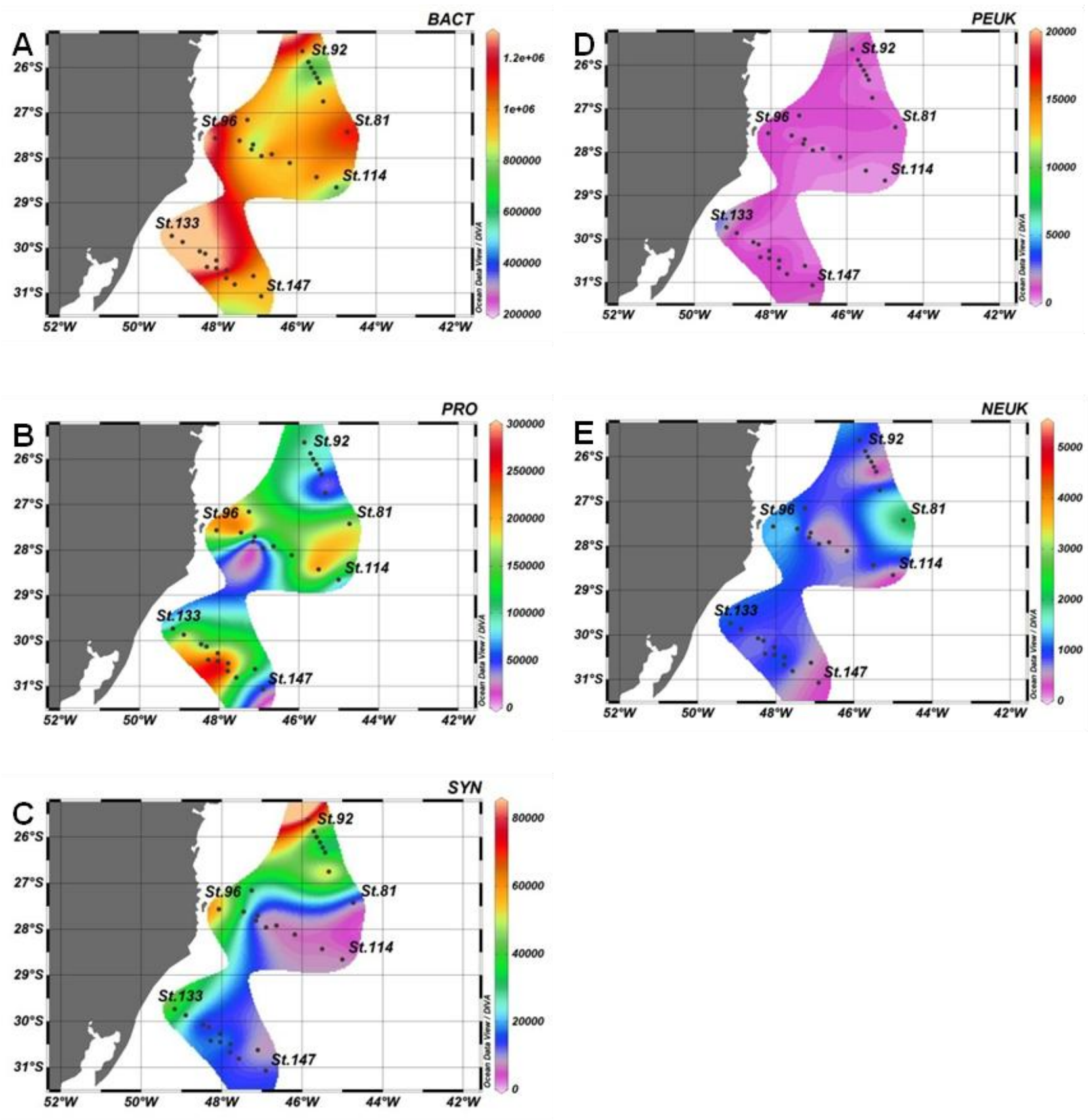

Figure 1.9. Surface distribution of total heterotrophic bacteria (A), Prochlorococcus (B), Synechococcus (C), picoeukaryotes (D) and nanoeukaryotes (E) (in cells. $\mathrm{mL}^{-1}$ ) for transects 1, 2 and 3; numbers indicate the beginning and the end of each transect; black dots indicate each station. 


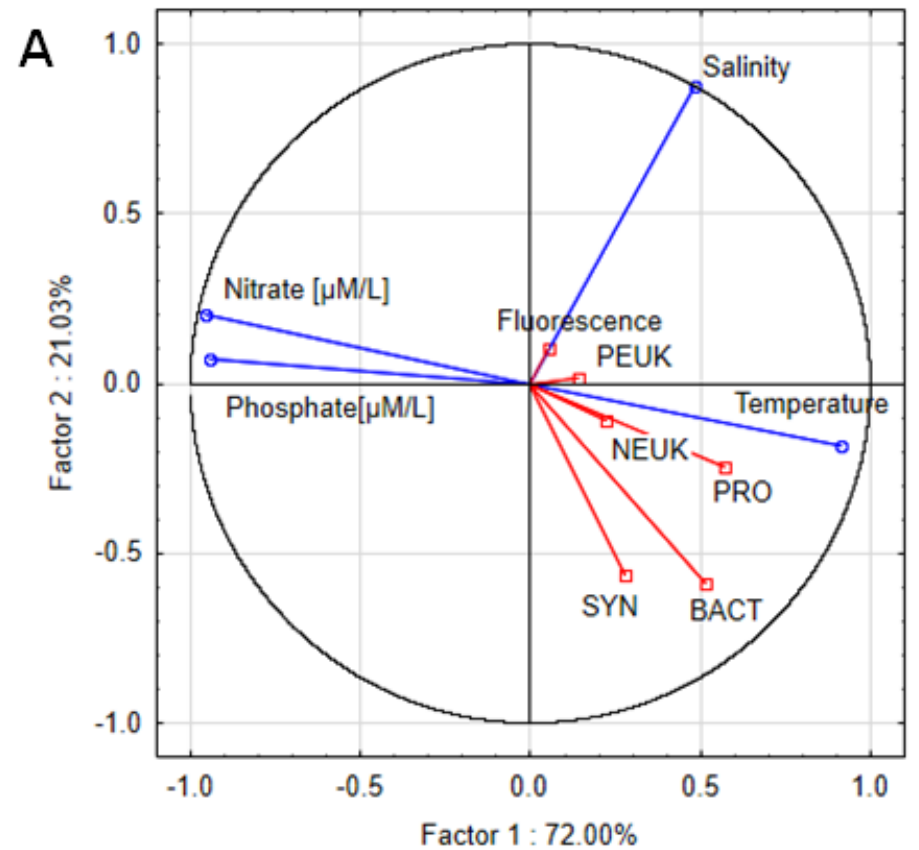

- Active

a Suppl.

B

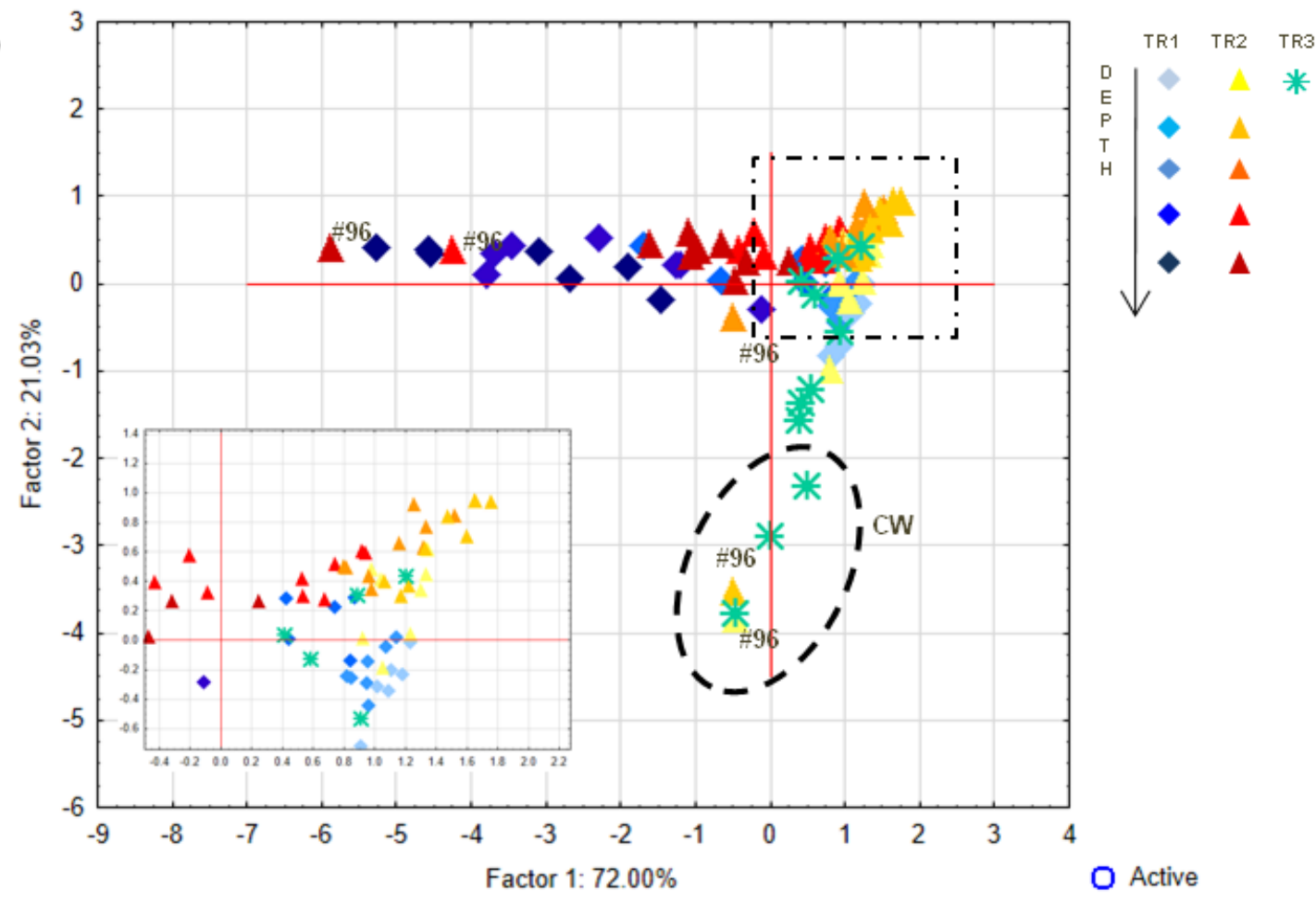

Figure 1.10. Principal Component Analysis (PCA) showing (A) total heterotrophic bacteria, Prochlorococcus, Synechococcus, picoeukaryotes, nanoeukaryotes and chlorophyll fluorescence (supplementary variables) in relation with temperature, salinity, nitrates and phosphates; (B) distribution of the stations. Dashed ellipse indicates samples from Coastal Water (CW), dashed square indicates the zoom window; \#96 refers to samples from St. 96. 


\subsubsection{Carbon biomass of microbe populations}

Picoplankton carbon biomass (Figure 1.11 and 1.12 - A, C) was estimated from cell abundance obtained by flow cytometry using conversion factors from the literature (BUITENHUIS et al., 2012; LEE; FUHRMAN, 1987). BACT biomass ranged from $4 \mu \mathrm{gC} . \mathrm{L}^{-1}$ to $33 \mu \mathrm{gC} . \mathrm{L}^{-1}$, and dominated carbon picoplankton biomass (67\% on average, ranging from 26 to 99\%) (Figures 1.11 and 1.12 - B, D). PRO contributed more to total pico-phytoplanktonic biomass in oligotrophic and warmer TW, reaching 66\% $\left(9 \mu \mathrm{gC} . \mathrm{L}^{-1}\right.$, TR1, St. 81 , 80 meters depth) and $87 \%$ ( $8 \mu \mathrm{gC} . \mathrm{L}^{-1}$, TR2, St. 98, 50 meters depth) of total autotrophic carbon (Figures 1.11 and 1.13 - A, D). PRO mean relative contribution to total autotrophic biomass was $22 \%, 43 \%$ and $48 \%$ in TR1, TR2 and TR3, respectively. SYN biomass contribution to total autotrophic biomass was high throughout TW in TR1 (81\%, St. 85) and at the innermost stations, mainly in CW and shelf waters, in TR2 (70\%, St. 96) and TR3 (maximum of 53\%, St. 133) (Figures 1.11, Figure 1.13 - B, D and Figure 1.15). PEUK biomass relative importance was higher in deeper samples near DCM, reaching 90\% of total autotrophic biomass in TR1 (St. 89) and 91\% in TR2 (St. 98). On average, PEUK contributed to $25 \%$ of pico-phytoplankton biomass, falling below 15\% in the uppermost layers of TW (Figure 1.11 and Figure 1.14 - A, B). 
Biomass $\left(\mu g C \cdot L^{-1}\right)$ in TR1

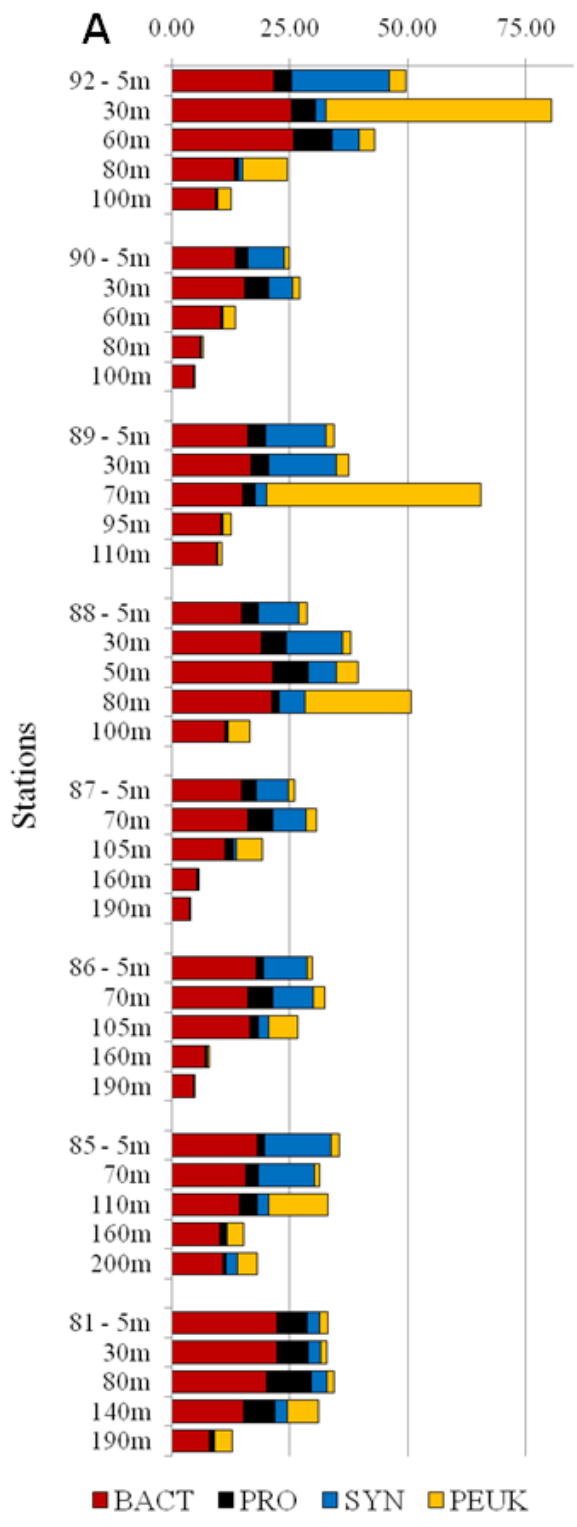

Biomass $\left(\mu \mathrm{gC.L} \mathrm{L}^{-1}\right)$ in TR2

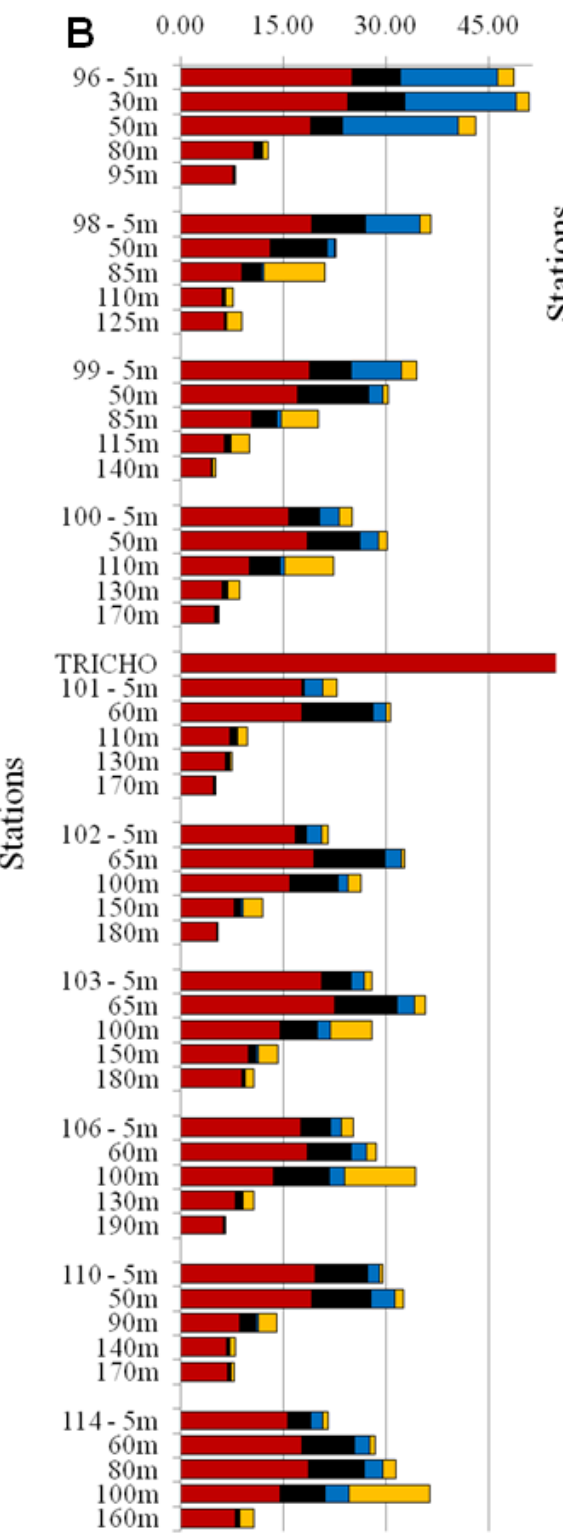

Biomass $\left(\mu \mathrm{gC.L} \mathrm{L}^{-1}\right)$ in TR3

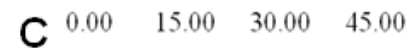

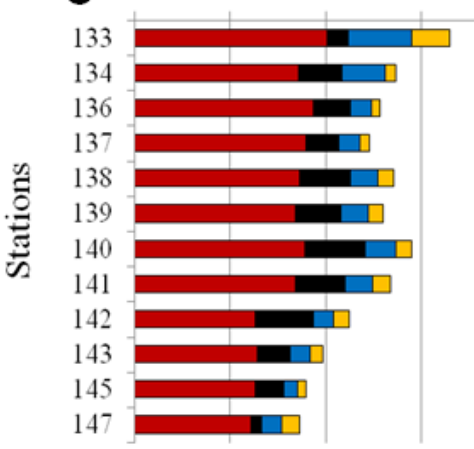

Figure 1.11. Biomass $\left(\mu \mathrm{gC} \cdot \mathrm{mL}^{-1}\right)$ estimated for total heterotrophic bacteria (BACT), Prochlorococcus (PRO), Synechococcus (SYN) and picoeukaryotes (PEUK) for TR1 $(\mathbf{A})$, TR2 (B) and TR3 (C). Note that the scale for TR1 is different from TR2 and TR3. 


\section{TR1}
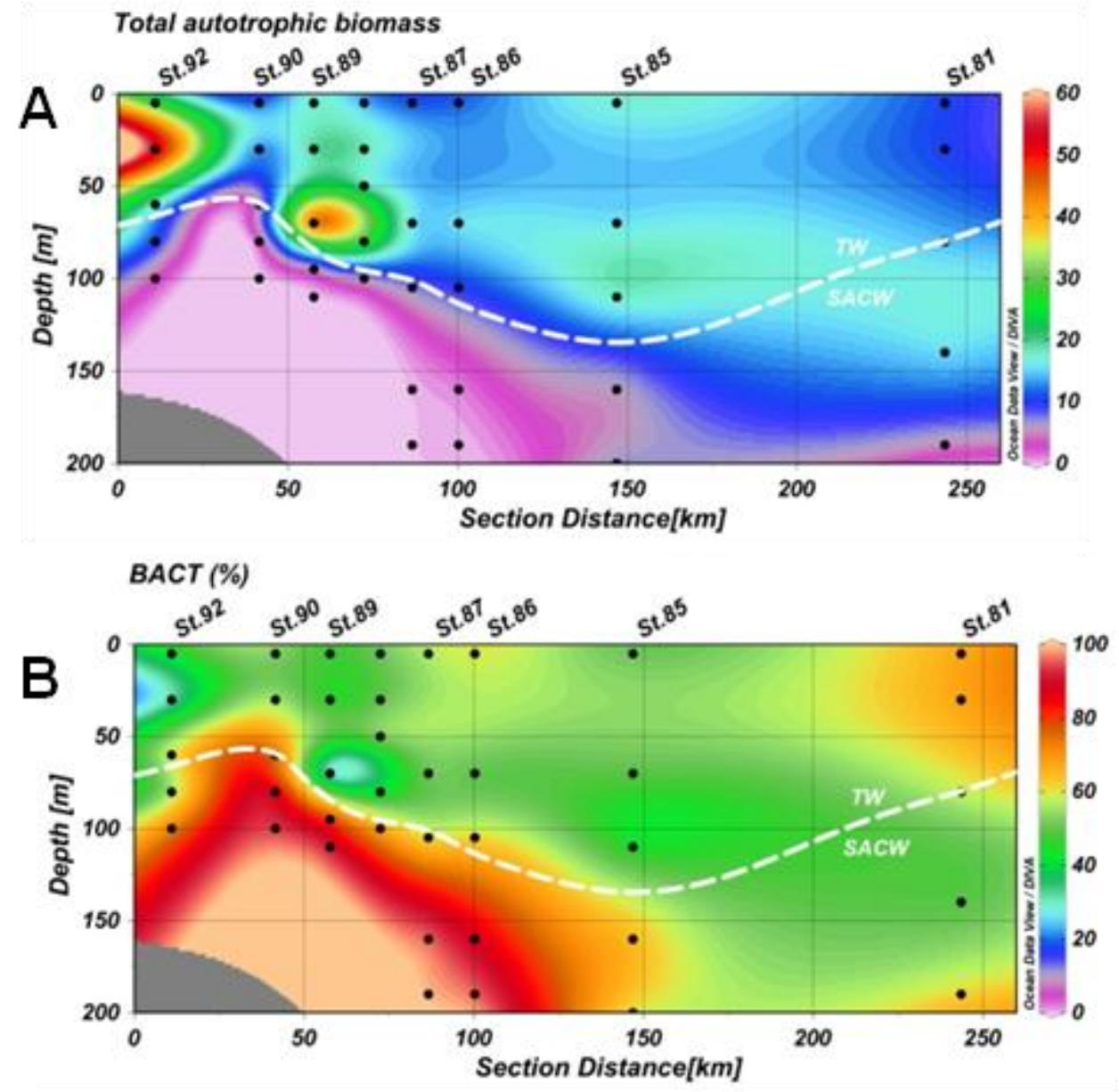

TR2
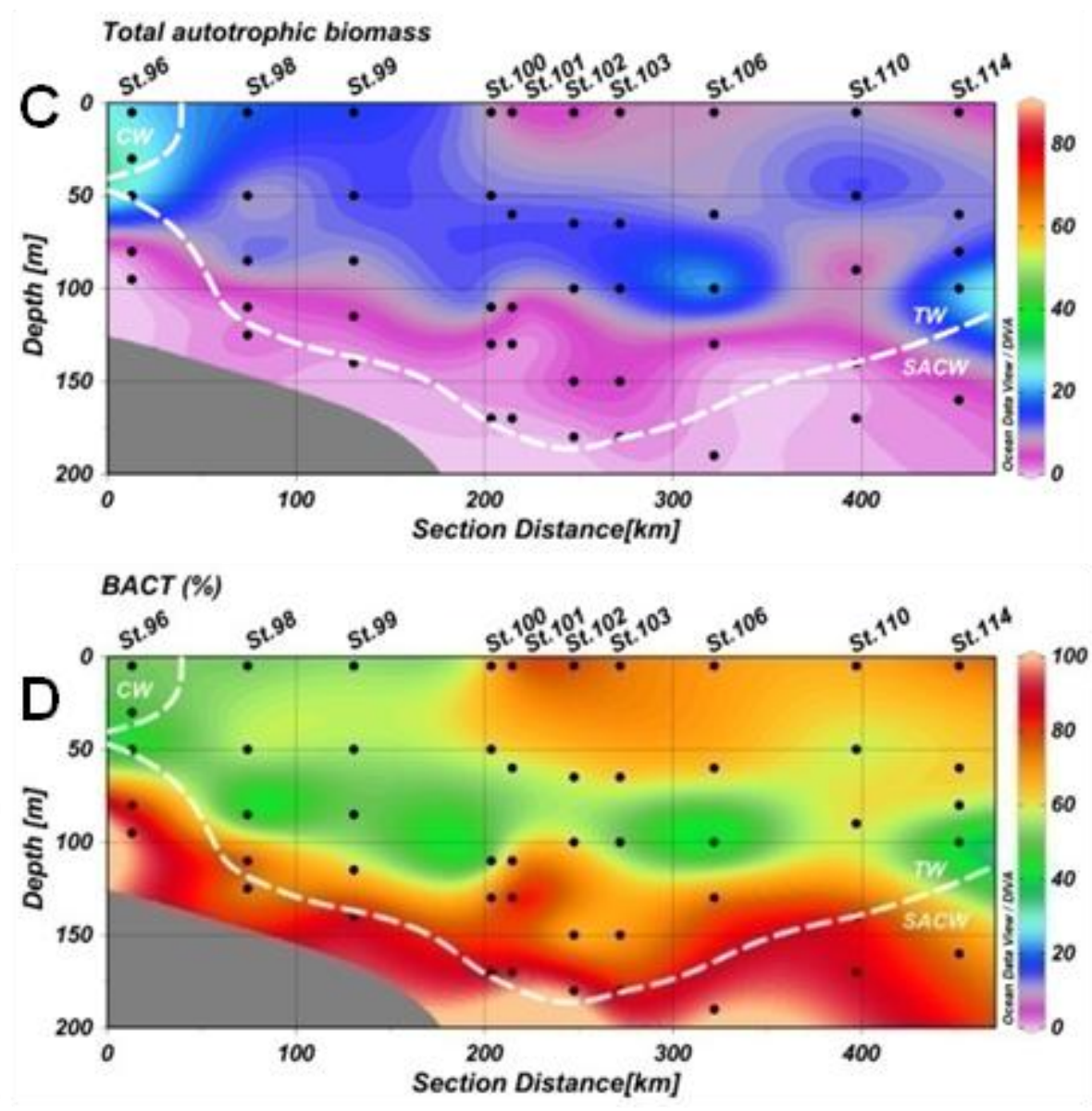

Figure 1.12. Vertical distribution of total autotrophic biomass $\left(\mu \mathrm{gC}^{-1} \mathrm{~L}^{-1}\right)$ and relative contribution to total biomass $(\%)$ of total heterotrophic bacteria for transect 1 (A, B) and transect 2 (C, D); numbers indicate sampling stations; black dots indicate sampling depths; water masses are delimitated in white: Tropical Water (TW); South Atlantic Central Water (SACW) and Coastal Water (CW). 
TR1

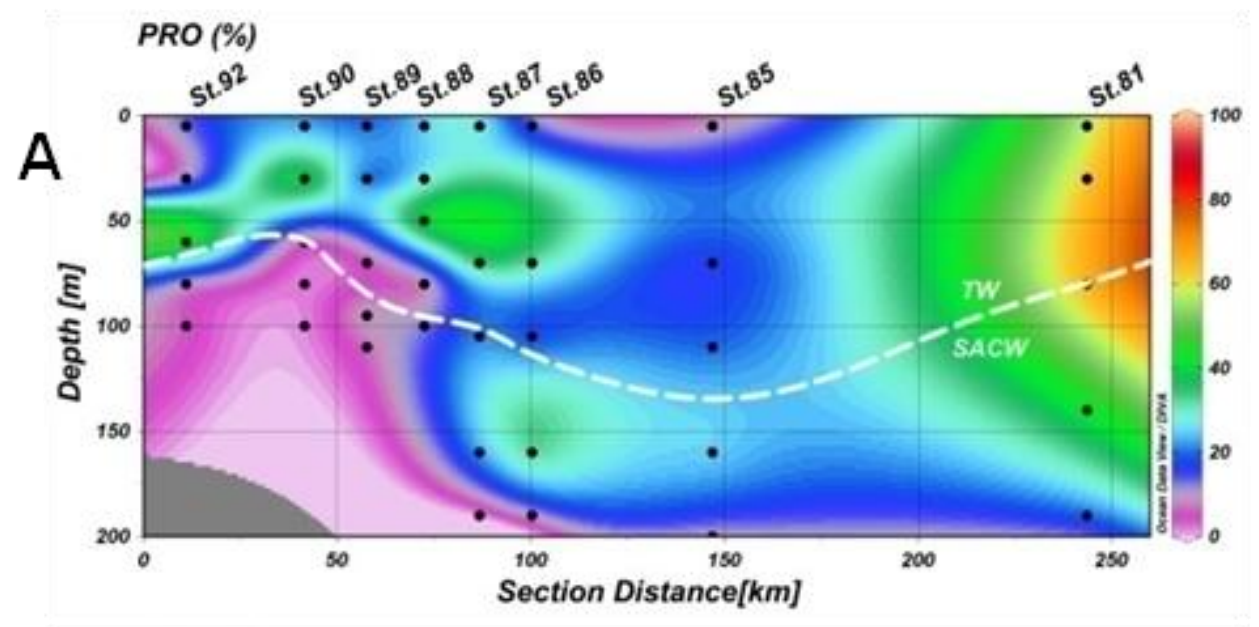

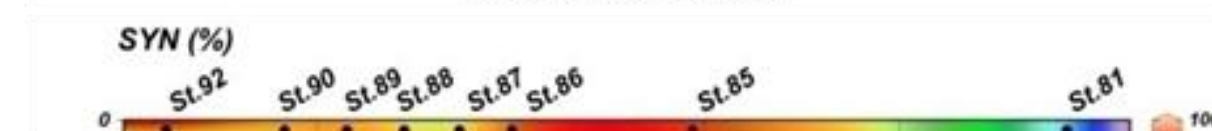

B

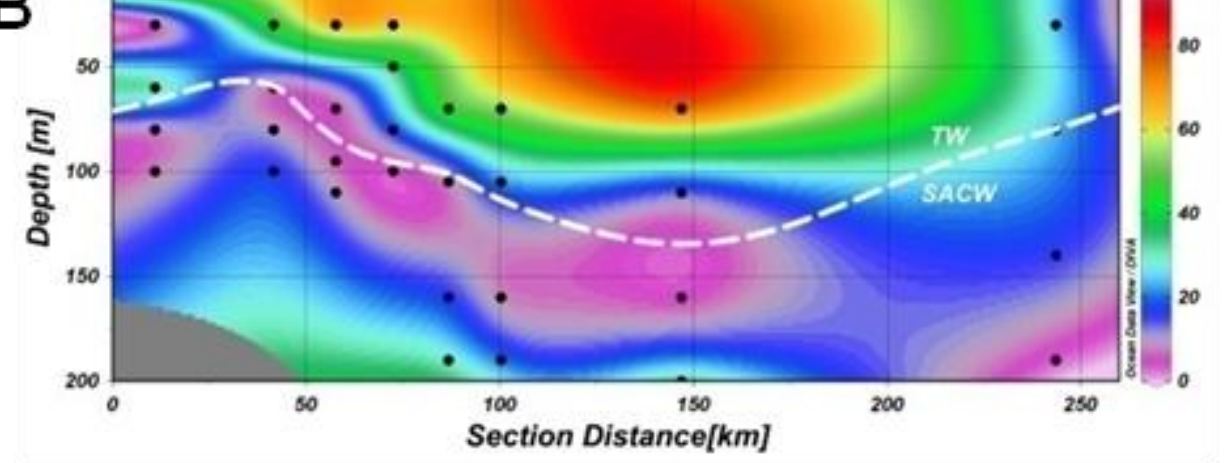

\section{TR2}
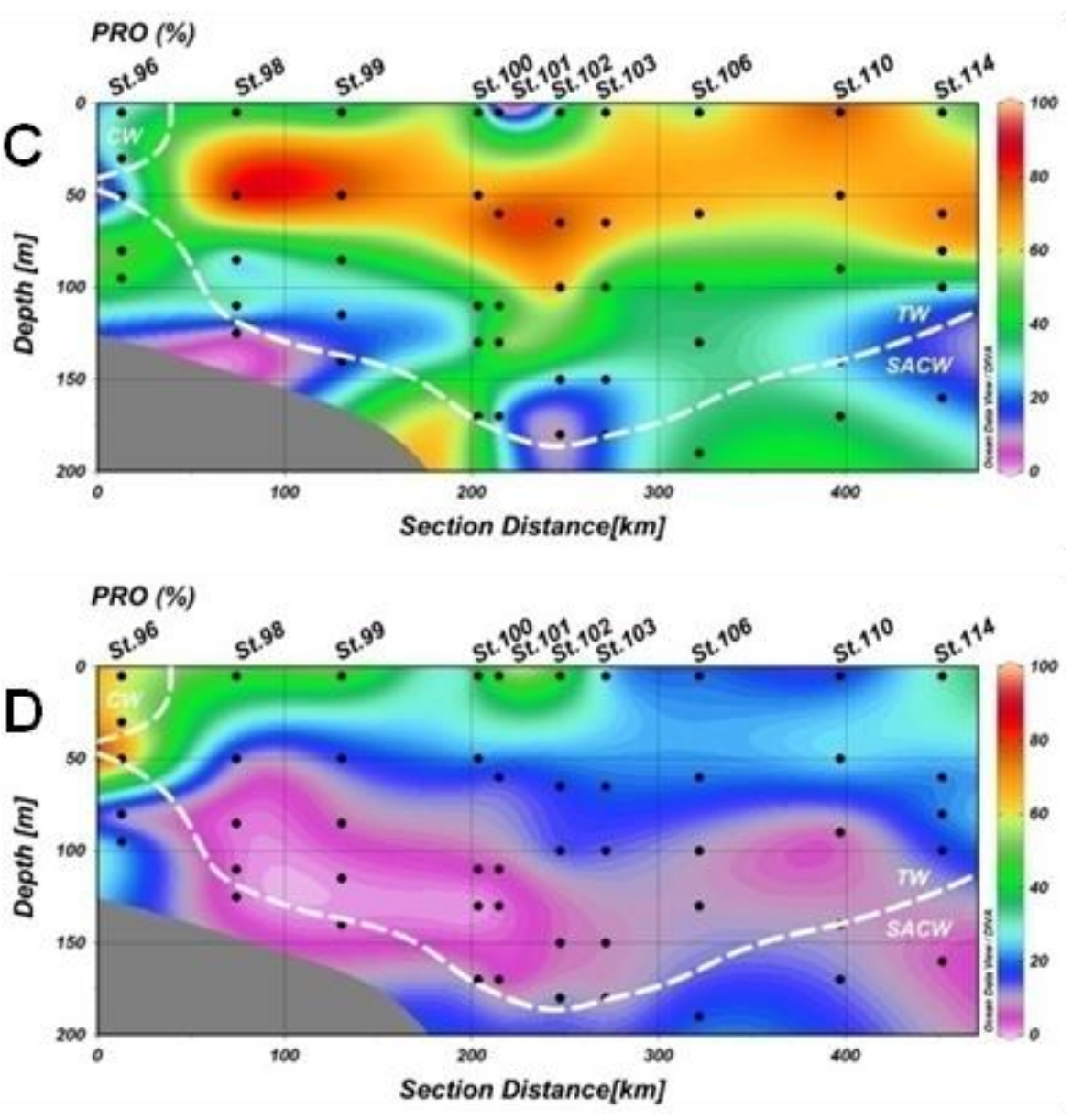

Figure 1.13. Vertical distribution of relative contribution to total biomass (\%) of Prochlorococcus and Synechococcus for transect 1 (A, B) and transect 2 (C, D); numbers indicate sampling stations; black dots indicate sampling depths; water masses are delimitated in white: Tropical Water (TW); South Atlantic Central Water (SACW) and Coastal Water (CW). 


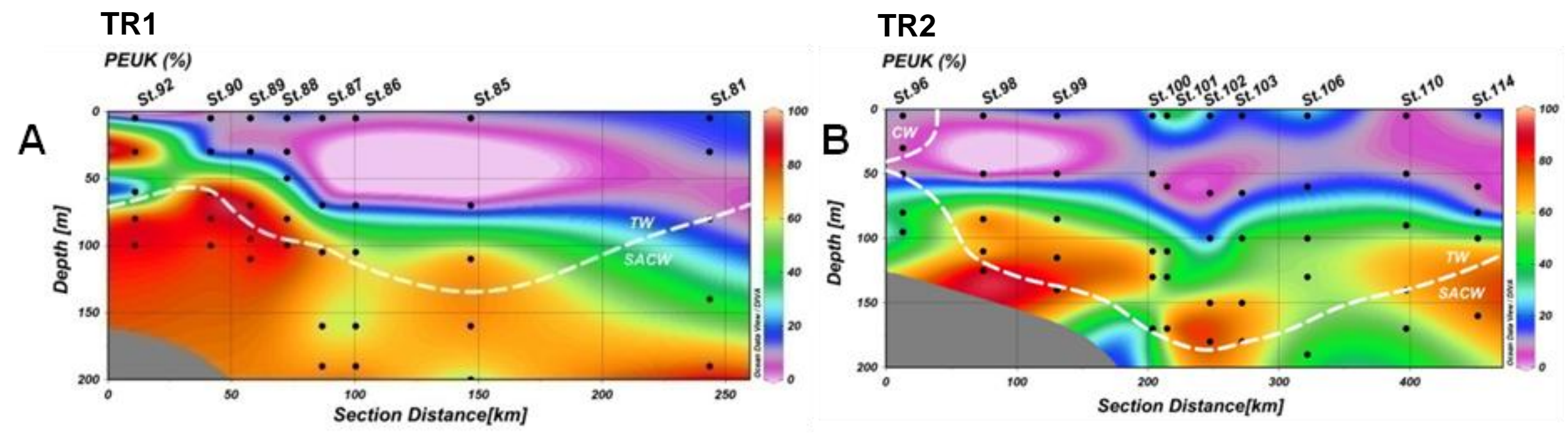

Figure 1.14. Vertical distribution of relative contribution to total biomass (\%) of picoeukaryotes for transect 1 (A) and transect 2 (B); numbers indicate sampling stations; black dots indicate sampling depths; water masses are delimitated in white: Tropical Water (TW); South Atlantic Central Water (SACW) and Coastal Water (CW). 

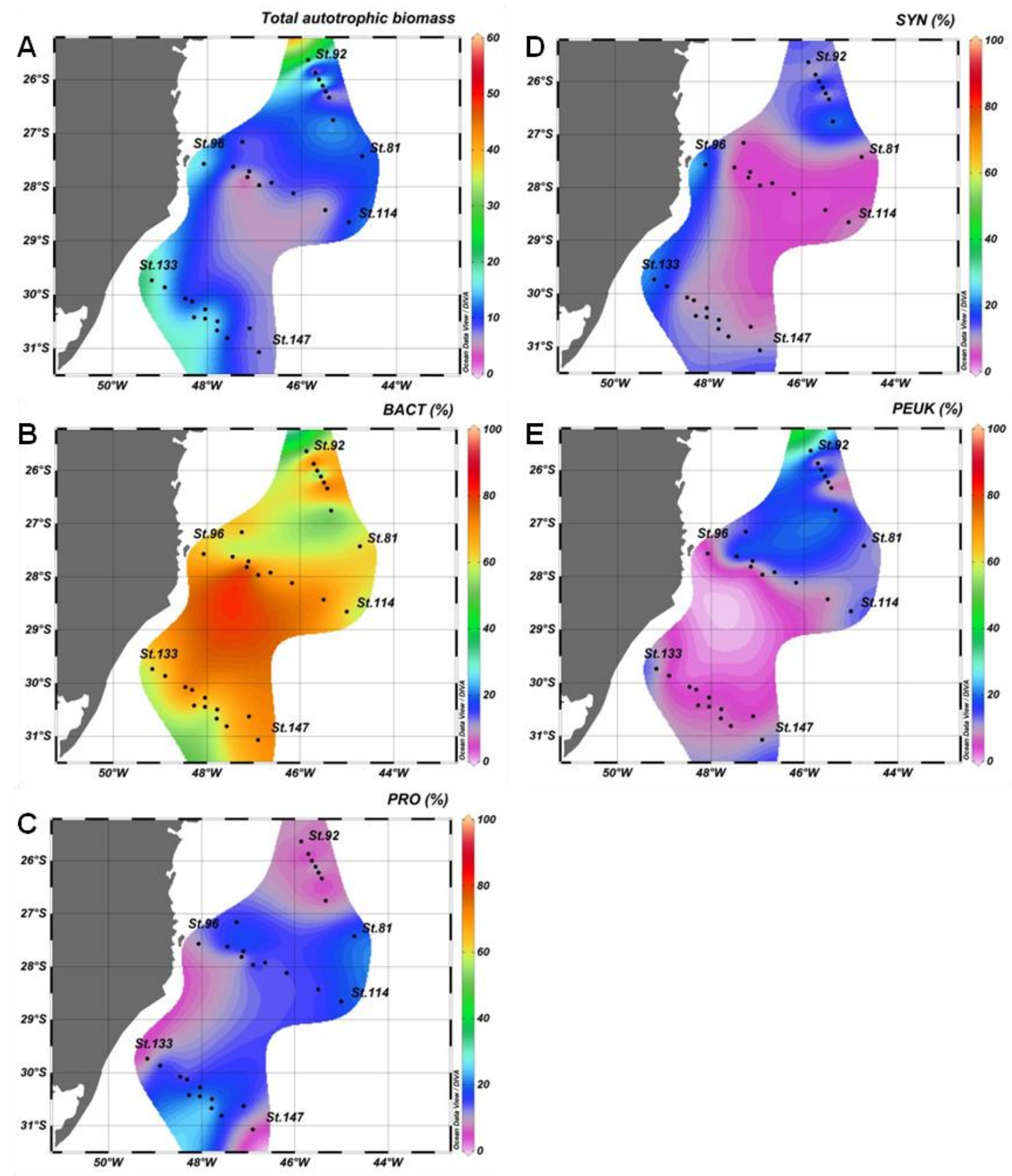

Figure 1.15. Surface distribution of total autotrophic biomass $\left(\mu g \mathrm{gC}^{-1}\right)(\mathbf{A})$, relative contribution to total biomass (\%) of total heterotrophic bacteria (B), Prochlorococcus (C), Synechococcus (D) and picoeukaryotes (E) for transects 1, 2 and 3; numbers indicate the beginning and the end of each transect; black dots indicate each station. 


\subsubsection{Pico and nano-phytoplankton phylogenetic composition}

We obtained 30 plastidial sequences of 16S rRNA (Figures 1.16, Table S2) from pico- and nanoeukaryotes populations sorted by flow cytometry from 3 stations along TR2 in SWAO off Brazil. The plastid sequences corresponded to 11 unique sequences, that could be grouped into 6 distinct OTUs (Figure 1.16). Sequences were dominated by Prymnesiophyceae (26 sequences) (Figure 1.17), mainly related to Braarudosphaeraceae (22 sequences). Other sequences belonged to Heterokontophyta (Chrysophyceae and Dictyochophyceae, 4 sequences). NEUK sequences were mostly affiliated to Braarudosphaeraceae and prymnesiophytes clade B2, whilst PEUK sequences were distributed within Braarudosphaeraceae, Isochrysidales, Chrysophyceae and Dictyochophyceae (Figure 1.16). Two sequences were recovered from the superficial samples of the Trichodesmium spp. bloom (1 from PEUK and 1 from NEUK), both of them related to Braarudosphaeraceae. 


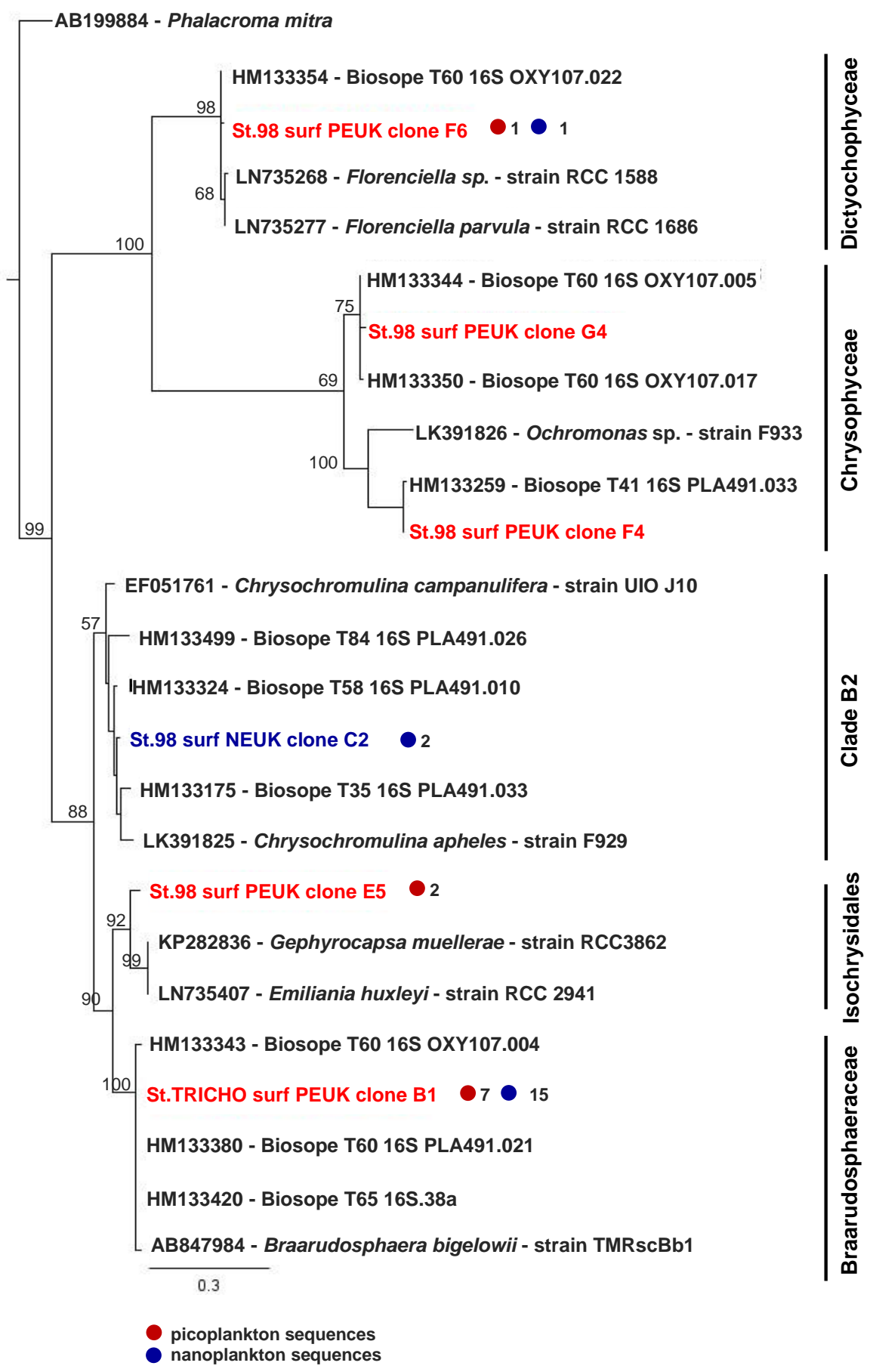

Figure 1.16. Phylogenetic tree of plastid 16S rRNA gene sequences. Sequences were retrieved from photosynthetic pico- and nanoeukaryotes sorted by flow cytometry in the Southwest Atlantic Ocean. The tree is inferred from 537 positions of an alignment of 25 partial sequences. The phylogenetic tree was constructed by the maximum likelihood (ML) method based on a TN93 (Tamura-Nei) model of nucleotides substitution. Bootstrap values over $50 \%$ are indicated on the internal branches. Sequences in bold are representative of OTUs obtained in the present study. Red and blue labeling refers to sequences retrieved from the pico- and nanoplankton, respectively. Numbers with symbols correspond to the number of clones retrieved for each OTU. 


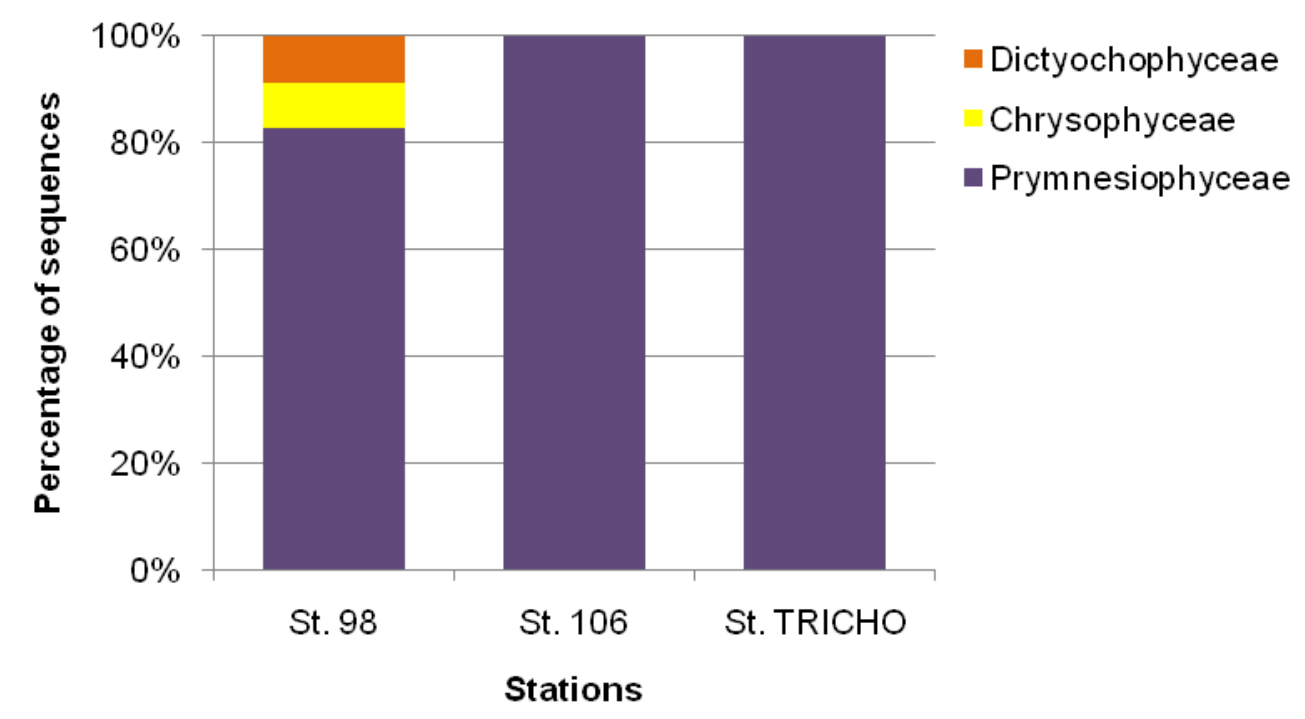

Figure 1.17. Composition of 16S rRNA sequences (total of 30 sequences) from pico- and nanoplanktonic sorted cells at three stations. 


\subsection{DISCUSSION}

In the present study, we assessed the distribution of pico- and nanoplankton populations over cross-shelf profiles, in order to observe the influence of mesoscale dynamics on the biomass and population structure of epipelagic picoplankton communities.

One of the most important processes for primary productivity in the euphotic zone along SAO is the South Atlantic Central Water intrusion over the continental shelf, along with interactions with Tropical Water and Coastal Water (CASTRO et al., 2006), which generate spatial variations in temperature, salinity, nutrients and light availability (BRANDINI, 1990b; MOSER et al., 2014; PEREIRA BRANDINI et al., 2014). Apart from some phosphate enrichment, low nutrient concentration were found in CW (Figures 1.3 - B, D and 1.4 - A, B), which is expected, since the region is not influenced by any significant continental drainage. Vertical chlorophyll fluorescence maxima seem to correlate with the thermocline upward displacement, near continental slope and a prominent DCM layer is visible throughout transects (TR1 and TR2) (Figure 1.3 - A, C). SACW upward displacement in the outermost stations can be a consequence of both meandering activity or internal gravity waves, which are known to be able to raise the thermocline into the euphotic zone (JOHANNESSEN, 1968), and may be responsible for the increase in fluorescence at depth at St 81 in TR1. 
The variation of the abundance of each group among transects was within the concentration range described for other coastal shelf systems and oligotrophic oceanic waters (KATANO et al., 2005; ZUBKOV et al., 1998). In general, BACT distribution tends to follow pico-phytoplankton biomass structure along the water column, which has been reported before in the Atlantic ocean (ZUBKOV et al., 1998, 2000). The increased BACT abundance on the thermocline elevation (Figure 1.6 - A, C) can be related to the accumulation of dissolved and particulate organic matter in frontal regions (LINACRE et al., 2015). BACT abundance values reported here $\left(0.2 \times 10^{6}-1.5 \times 10^{6}\right.$ cells. $\left.\mathrm{mL}^{-1}\right)$ are consistent with those found in other studies in different regions in the coast of Brazil (ANDRADE; GONZALEZ, 2007; ANDRADE et al., 2003), in the Atlantic Ocean (ZUBKOV et al., 1998), as well as in other marine ecosystems (GROB et al., 2007; HERFORT et al., 2012; ŠILOVIĆ et al., 2012).

PRO importance to primary productivity in oligotrophic regions is well documented (BILLER et al., 2015), and its abundance tend to peak in highly stratified upper layers (JOHNSON et al., 2006), with a wide vertical distribution linked to the coexistence of differently adapted ecotypes (BOUMAN et al., 2006; MOORE; ROCAP; CHISHOLM, 1998; WEST et al., 2001). PRO outnumbered the other pico-phytoplanktonic groups in all transects, with a mean concentration of $100 \times 10^{3}$ cells. $\mathrm{mL}^{-1}$. The observed concentration range agrees with reports in the western boundary of the South Atlantic Gyre (ZUBKOV et al., 2000) as well as in other marine ecosystems (GROB et al., 2007; GUO et al., 2014; VAULOT; MARIE, 1999). PRO local maxima was apparently correlated with the upper edge of thermocline raise $\left(200 \times 10^{3}\right.$ cells. $\left.\mathrm{mL}^{-1}\right)$, in TR1. In TR2, PRO was particularly abundant over the first $100 \mathrm{~m}$ of TW. The absence of 
significant correlation between PRO and nitrates is expected (Figure 1.10), since previous studies have shown that most Prochlorococcus strains lack the genes required for $\mathrm{NO}_{3}$ uptake and reduction (MOORE et al., 2002).

SYN high cell abundances are associated with the presence of tropical and sub-tropical mesotrophic waters and upwelling events (VAN DONGENVOGELS et al., 2011; ZUBKOV et al., 1998). In the present study, SYN higher abundances (up to $81 \times 10^{3}$ cells. $\mathrm{mL}^{-1}$ ) were found mostly in superficial, shelf waters, in association with the thermocline upward displacement (Figure 1.7 A, C). Values from the highest abundances found on the three transects suggest a coastward enhancement on SYN populations, which has been reported in other studies (JIAO et al., 2002), but also indicate a decrease towards the South (Figure 1.9 - C). Latitudinal abundance shifts are expected, since Synechococcus niche partitioning can be dictated by individual clade preferences for temperature, macronutrients and iron availability (SOHM et al., 2015).

The mean picoeukaryotic abundance obtained in this study $\left(1 \times 10^{3}\right.$ cells. $\mathrm{mL}^{-1}$ ) is in accordance with averages observed for oligotrophic waters (WORDEN; NOT, 2008; ZUBKOV et al., 1998). Beyond the shelf break, PEUK abundances peaked in deeper samples, between $50 \mathrm{~m}$ and $100 \mathrm{~m}$ depth (Figure 1.7 - B, D). PEUK populations often form a deep water maximum, in tropical and subtropical oligotrophic waters, and an upper layer maximum, when upwelling or frontal systems pump nutrient rich waters into the euphotic zone (JIAO et al., 2002; ZUBKOV et al., 1998). The close relationship between DCM layers and PEUK abundance reported here, was described before at the western boundary of the southern Atlantic Gyre (ZUBKOV et al., 2000) as well 
as close to its center (TARRAN; HEYWOOD; ZUBKOV, 2006). Painter et al., (PAINTER et al., 2014) observed maximum picoeukaryote abundance coincident with maximum $\mathrm{NO}_{3}^{-}$uptake rates, near the nitracline, which indicate that PEUK populations might be major players in the production in the deeper layers in the euphotic zone, fueling the carbon downward flux to the ocean interior.

NEUK distribution was vertically wider than PEUK, extending from surface down to $200 \mathrm{~m}$ depth at some stations (Figure 1.8 A, B), which may reflect distinct habitat preferences, regarding light and nutrient availability, of a diverse assemblage of species. NEUK mean abundance was $1 \times 10^{3}$ cells. $\mathrm{mL}^{-1}$, which is comparable with previous estimates in TW (from $10^{2}$ to $10^{3}$ cells. $\mathrm{mL}^{-1}$ ) (MOSER et al., 2014).

Pico-phytoplankton biomass dominate nutrient poor, warm waters (AGAWIN; DUARTE; AGUSTI, 2000), and the same is observed for the oligotrophic waters of the SAO (MARAÑÓN et al., 2003). In TR2 and TR3, the presence of Coastal Water increased autotrophic carbon standing stocks (Figure 1.12 - C). The mean autotrophic picoplankton carbon concentration measured in this study $\left(21 \mu \mathrm{gC} \cdot \mathrm{L}^{-1}\right)$ is similar to estimates on global tropical regions (BUITENHUIS et al., 2012), and accounted, on average, for $38 \%$ of the total microbial biomass.

In TR1, besides the sharp enhancement on total pico-phytoplankton biomass above the thermocline raise, its distribution was particularly homogeneous after the shelf break (Figure 1.12 - A). A high percentage of autotrophic biomass was strongly linked to the thermocline raise near shelf break, reaching up to $77 \%$ of total biomass (Figure 1.12 - A), which is 
comparable to the highest measurements observed in the Atlantic Ocean (MARAÑÓN et al., 2001; PÉREZ et al., 2005).

The physical structure of the water column near continental shelves have a great impact in the relative dominance of each picoplankton group (JIAO et al., 2002; LINACRE et al., 2015; VAN DONGEN-VOGELS et al., 2011). BACT accounted for a large fraction of total biomass in deeper samples, at the lower limit of the euphotic zone, where autotrophic populations decreased (Figure 1.12 - B, D). SYN and PEUK biomass had a higher relative importance near the SACW intrusion and the thermocline raise. SYN and PEUK biomass enhancements has been linked to the destabilization of the water column caused by upwelling process in other coastal shelf systems (VAN DONGENVOGELS et al., 2011). Although outnumbered by most of other picoplankton groups, PEUK biomass comprised a substantial fraction of the autotrophic carbon, particularly in deeper samples, which was observed before in oligotrophic Atlantic waters (ZUBKOV et al., 1998). While TR1 was dominated by SYN and PEUK biomass, TR2 was dominated by PRO populations (Figures 1.13 and 1.14). The variation in dominance patters among transects is consistent with previous studies that described two types of picophytoplanktonic distributions: mesotrophic waters communities dominated by SYN and PEUK versus oligotrophic waters communities dominated by PRO (ZUBKOV et al., 1998). Most of the 16S rRNA sequences obtained in this study were assigned to haptophytes (Braarudosphaeraceae) implicated into symbioses with unicellular nitrogen-fixing cyanobacteria of the UCYN-A clade (HAGINO et al., 2013; THOMPSON et al., 2012). The haptophyte dominance among the sequences is most likely representative of their dominance in the 
samples. Although the primer used in this study (PLA491F) amplifies preferentially Haptophyta (SHI et al., 2011), it is also amplifies very well Chrysophyceae and Mamiellophyceae, which had two and none representatives, respectively, in the data set (Table S2). The presence of a large number Braarudosphaeraceae sequences in both the pico- and nanoplankton reflects the morphology variability within this family which include both coccoliths-bearing cells of $10-15 \mu \mathrm{m}$ size and smaller uncharacterized cells, a few microns in size (HAGINO et al., 2013; THOMPSON et al., 2012). Interestingly, we also found Braarudosphaeraceae at the TRICHO station, hinting that UCYN-A may co-occur with Trichodesmium. Previous studies have reported UCYN-A occurrences in the Western Equatorial Atlantic (FOSTER et al., 2007; GOEBEL et al., 2010), which may suggest that nitrogen input by diazotrophic organisms in SAO off Brazil may be greater than previously thought.

The data obtained with this study help to fill a gap in the knowledge about pico- and nanoplankton distribution in a very important but under-sampled area of the world ocean. The unexpected dominance of haptophytes implicated in nitrogen-fixing symbioses suggests it might be an important source of new nitrogen, impacting the primary productivity in the region. 


\subsection{CONCLUSIONS}

We observed the influence of the hydrographic regime of SAO off Brazil on the abundance and carbon biomass distribution of pico- and nanoplanktonic communities. This first prospection on pico- and nanoplankton diversity raised important questions about the coupling of nitrogen and carbon cycles in the region, since a symbiosis between an Haptophyta and an unicellular diazotrophic cyanobacteria (UCYN-A) was highly represented, even in a small clone library.

Further studies should address whether the distribution of water masses influences the pico- and nanoplankton diversity throughout the water column, and how it changes seasonally. It would be of high interest to investigate the impact of the Haptophyta + UCYN-A diazotrophic symbiosis on nitrogen fixation rates, in comparison to other known diazotrophic organisms in the region (e.g. Trichodesmium sp.). 


\subsection{REFERENCES}

AGAWIN, N.; DUARTE, C.; AGUSTI, S. Nutrient and temperature control of the contribution of picoplankton to phytoplankton biomass and production. Limnology and Oceanography, v. 45, n. 3, p. 591-600, 2000.

ALVES JUNIOR, N. et al. Microbial community diversity and physical-chemical features of the Southwestern Atlantic Ocean. Archives of microbiology, v. 197, n. 2, p. 165-79, 10 set. 2015.

ANDRADE, L. et al. Flow cytometry assessment of bacterioplankton in tropical marine environments. Journal of Microbiological Methods, v. 55, n. 3, p. 841-850, dez. 2003.

ANDRADE, L.; GONZALEZ, A. Distribution of HNA and LNA bacterial groups in the Southwest Atlantic Ocean. Brazilian Journal of Microbiology, v. 38, n. 2, p. 330-336, 2007.

BILLER, S. J. et al. Prochlorococcus: the structure and function of collective diversity. Nature Publishing Group, v. 13, n. 1, p. 13-27, 2015.

BOUMAN, H. A et al. Oceanographic basis of the global surface distribution of Prochlorococcus ecotypes. Science, v. 312, n. 5775, p. 918-21, 12 maio 2006.

BRANDINI, F. P. Hydrography and characteristics of the phytoplankton in shelf and oceanic waters off southeastern Brazil during winter (July/August 1982) and summer (February/March 1984). Hydrobiologia, v. 196, n. 2, p. 111-148, 1990a.

BRANDINI, F. P. Produção primária e características fotossintéticas do fitoplâncton na região sueste do Brasil. Brazilian Journal of Oceanography, v. 38, n. 2, p. 147-159, 1990b.

BUITENHUIS, E. T. et al. Picophytoplankton biomass distribution in the global ocean. Earth System Science Data, v. 4, n. 1, p. 37-46, ago. 2012.

CAMPOS, E. J. D.; VELHOTE, D.; DA SILVEIRA, I. C. A. Shelf break upwelling driven by Brazil current cyclonic meanders. Geophysical Research Letters, v. 27, n. 6, p. 751-754, 2000.

CAMPOS, E. J. D.; VELHOTE, D.; SILVEIRA, I. C. A. Shelf break upwelling driven by Brazil current cyclonic meanders. Geophysical Research Letters, v. 27, n. 6, p. 751-754, 2000.

CASTRO, B. M. et al. Physical oceanography of the western Atlantic continental shelf located between $4 \mathrm{~N}$ and $34 \mathrm{~S}$. The sea, v. 11, p. 209-251, 2006. 
EMÍLSSON, I. The shelf and coastal waters off southern brazil. Boletim do Instituto Oceanográfico, v. 11, n. 2, p. 101-112, 1961.

FERNANDES, L. F.; BRANDINI, F. P. Diatom associations in shelf waters off Paraná state, Southern Brazil: annual variation in relation to environmental factors. Brazilian Journal of Oceanography, v. 52, n. 1, p. 19-34, 2004.

FOSTER, R. A. et al. Influence of the Amazon River plume on distributions of free-living and symbiotic cyanobacteria in the western tropical north Atlantic Ocean. Limnology and Oceanography, v. 52, n. 2, p. 517-532, 2007.

FULLER, N. J. et al. Clade-Specific 16S Ribosomal DNA oligonucleotides reveal the predominance of a single marine Synechococcus clade throughout a stratified water column in the Red Sea. Applied and Environmental Microbiology, v. 69, n. 5, p. 2430-2443, 2003.

FULLER, N. J. et al. Analysis of photosynthetic picoeukaryote diversity at open ocean sites in the Arabian Sea using a PCR biased towards marine algal plastids. Aquatic Microbial Ecology, v. 43, p. 79-93, maio 2006.

GOEBEL, N. L. et al. Abundance and distribution of major groups of diazotrophic cyanobacteria and their potential contribution to N2 fixation in the tropical Atlantic Ocean. Environmental Microbiology, v. 12, p. 3272-3289, 2010.

GROB, C. et al. Contribution of picoplankton to the total particulate organic carbon concentration in the eastern South Pacific. Biogeosciences, v. 4, p. 837-852, 2007.

GUINDON, S. et al. New algorithms and methods to estimate maximumlikelihood phylogenies: assessing the performance of PhyML 3.0. Systematic Biology, v. 59, n. 3, p. 307-321, 2010.

GUO, C. et al. Seasonal and spatial patterns of picophytoplankton growth, grazing and distribution in the East China Sea. Biogeosciences, v. 11, n. 7, p. 1847-1862, 8 abr. 2014.

HAGINO, $K$. et al. Discovery of an endosymbiotic nitrogen-fixing cyanobacterium UCYN-A in Braarudosphaera bigelowii (Prymnesiophyceae). PloS one, v. 8, n. 12, p. e81749, jan. 2013.

HERFORT, L. et al. Red waters of Myrionecta rubra are biogeochemical hotspots for the Columbia River estuary with impacts on primary/secondary productions and nutrient cycles. Estuaries and Coasts, v. 35, p. 878-891, 2012.

JIAO, N. Z. et al. Influence of hydrographic conditions on picoplankton distribution in the East China Sea. Aquatic Microbial Ecology, v. 30, n. 1, p. 37-48, 2002. 
JOHANNESSEN, O. M. Note on some hydrographical and current observations from three positions on the brazilian shelf in the region of Cabo Frio-Santos 1966. Contribuições Avulsas do Instituto Oceanográfico, n. 10, p. 1-8, 1968.

JOHNSON, Z. I. et al. Niche partitioning among Prochlorococcus ecotypes along ocean-scale environmental gradients. Science, v. 311, n. 5768, p. 17371740, 2006.

KATANO, T. et al. Seasonal changes in the abundance and composition of picophytoplankton in relation to the occurrence of "Kyucho" and bottom intrusion in Uchiumi Bay, Japan. Marine Ecology, v. 298, n. 59, p. 59-67, 2005.

KEARSE, M. et al. Geneious Basic: an integrated and extendable desktop software platform for the organization and analysis of sequence data. Bioinformatics (Oxford, England), v. 28, n. 12, p. 1647-9, 2012.

LEE, S.; FUHRMAN, J. Relationships between biovolume and biomass of naturally derived marine bacterioplankton. Applied and Environmental Microbiology, v. 53, n. 6, p. 1298-1303, 1987.

LINACRE, L. et al. Distribution pattern of picoplankton carbon biomass linked to mesoscale dynamics in the southern gulf of Mexico during winter conditions. Deep Sea Research Part I: Oceanographic Research Papers, v. 106, p. 5567, 2015.

MARAÑÓN, E. et al. Patterns of phytoplankton size structure and productivity in contrasting open-ocean environments. Marine Ecology Progress Series, v. 216, p. 43-56, 2001.

MARAÑÓN, E. et al. High variability of primary production in oligotrophic waters of the Atlantic Ocean: Uncoupling from phytoplankton biomass and size structure. Marine Ecology Progress Series, v. 257, p. 1-11, 2003.

METZLER, P. M. et al. New and regenerated production in the South Atlantic off Brazil. Deep-Sea Research Part I: Oceanographic Research Papers, v. 44, n. 3, p. 363-384, 1997.

MOORE, L. R. et al. Utilization of different nitrogen sources by the marine cyanobacteria Prochlorococcus and Synechococcus. Limnology and Oceanography, v. 47, n. 4, p. 989-996, 2002.

MOORE, L. R.; ROCAP, G.; CHISHOLM, S. W. Physiology and molecular phylogeny of coexisting Prochlorococcus ecotypes. Nature, v. 393, n. 6684, p. 464-7, 4 jun. 1998.

MOSER, G. A O. et al. Phytoplankton spatial distribution on the Continental Shelf off Rio de Janeiro, from Paraíba do Sul River to Cabo Frio. Hydrobiologia, v. 728, n. 1, p. 1-21, 2014. 
PAINTER, S. C. et al. Picoeukaryote distribution in relation to nitrate uptake in the oceanic nitracline. Aquatic Microbial Ecology, v. 72, n. 3, p. 195-213, 2014.

PEREIRA BRANDINI, F. et al. Deep chlorophyll maximum and plankton community response to oceanic bottom intrusions on the continental shelf in the South Brazilian Bight. Continental Shelf Research, v. 89, p. 61-75, 2014.

PÉREZ, V. et al. Latitudinal distribution of microbial plankton abundance, production, and respiration in the Equatorial Atlantic in autumn 2000. Deep-Sea Research Part I: Oceanographic Research Papers, v. 52, p. 861-880, 2005.

SCHLOSS, P. D. et al. Introducing mothur: Open-source, platform-independent, community-supported software for describing and comparing microbial communities. Applied and Environmental Microbiology, v. 75, n. 23, p. 7537-7541, 2009.

SHI, X. L. et al. Plastid 16S rRNA gene diversity among eukaryotic picophytoplankton sorted by flow cytometry from the South Pacific Ocean. PloS one, v. 6, n. 4, p. e18979, jan. 2011.

ŠILOVIĆ, T. et al. Picoplankton seasonal variation and community structure in the northeast Adriatic coastal zone. FEMS Microbiology Ecology, v. 82, p. 678-691, 2012.

SOHM, J. A et al. Co-occurring Synechococcus ecotypes occupy four major oceanic regimes defined by temperature, macronutrients and iron. The ISME Journal, p. 1-13, 2015.

STRAMMA, L.; ENGLAND, M. On the water masses and mean circulation of the South Atlantic Ocean. Journal of Geophysical Research, v. 104, p. 896883, 1999.

SUSINI-RIBEIRO, S. M. M. Biomass distribution of pico-, nano- and microplankton on the continental shelf of Abrolhos, East Brazil. Archive of Fishery and Marine Research, v. 47, n. 2-3, p. 271-284, 1999.

SUSINI-RIBEIRO, S. M. M. et al. Topographical and hydrographical impacts on the structure of microphytoplankton assemblages on the Abrolhos Bank region, Brazil. Continental Shelf Research, v. 70, p. 88-96, 2013.

SVERDRUP, H. U.; JOHNSON, M. W.; FLEMING, R. H. The oceans, their physics, chemistry and general biology. New York: Englewood Cliffs, N.J., 1942.

TARRAN, G. A.; HEYWOOD, J. L.; ZUBKOV, M. V. Latitudinal changes in the standing stocks of nano- and picoeukaryotic phytoplankton in the Atlantic Ocean. Deep-Sea Research Part II: Topical Studies in Oceanography, v. 53, n. 14-16, p. 1516-1529, 2006.

THOMPSON, A. W. et al. Unicellular cyanobacterium symbiotic with a singlecelled eukaryotic alga. Science, v. 337, n. 6101, p. 1546-50, 21 set. 2012. 
VAN DONGEN-VOGELS, V. et al. Influence of local physical events on picophytoplankton spatial and temporal dynamics in South Australian continental shelf waters. Journal of Plankton Research, v. 33, n. 12, p. 18251841, 25 ago. 2011.

VAULOT, D.; MARIE, D. Diel variability of photosynthetic picoplankton in the equatorial Pacific. Journal of Geophysical Research, v. 104, p. 3297-3310, 1999.

VILLAC, M. C.; CABRAL-NORONHA, V. A. DE P.; PINTO, T. DE O. The phytoplankton biodiversity of the coast of the state of São Paulo, Brazil. Biota Neotropica, v. 8, n. 3, p. 151-173, 2008.

WEST, N. J. et al. Closely related Prochlorococcus genotypes show remarkably different depth distributions in two oceanic regions as revealed by in situ hybridization using 16S rRNA-targeted oligonucleotides. Microbiology, v. 147, p. 1731-1744, 2001.

WORDEN, A. Z.; NOT, F. Ecology and Diversity of Picoeukaryotes. In: KIRCHMAN DL (Ed.). . Microbial Ecology of the Oceans: Second Edition. 2nd. ed. New York: Wiley-Liss, 2008. p. 159-205.

ZUBKOV, M. V et al. Picoplanktonic community structure on an Atlantic transect from $50^{\circ} \mathrm{N}$ to $50^{\circ} \mathrm{S}$. Deep Sea Research Part I: Oceanographic Research Papers, v. 45, n. 8, p. 1339-1355, ago. 1998.

ZUBKOV, M. V. et al. Picoplankton community structure on the Atlantic Meridional Transect: A comparison between seasons. Progress in Oceanography, v. 45, n. 3-4, p. 369-386, 2000. 


\subsection{SUPPLEMENTARY MATERIAL}

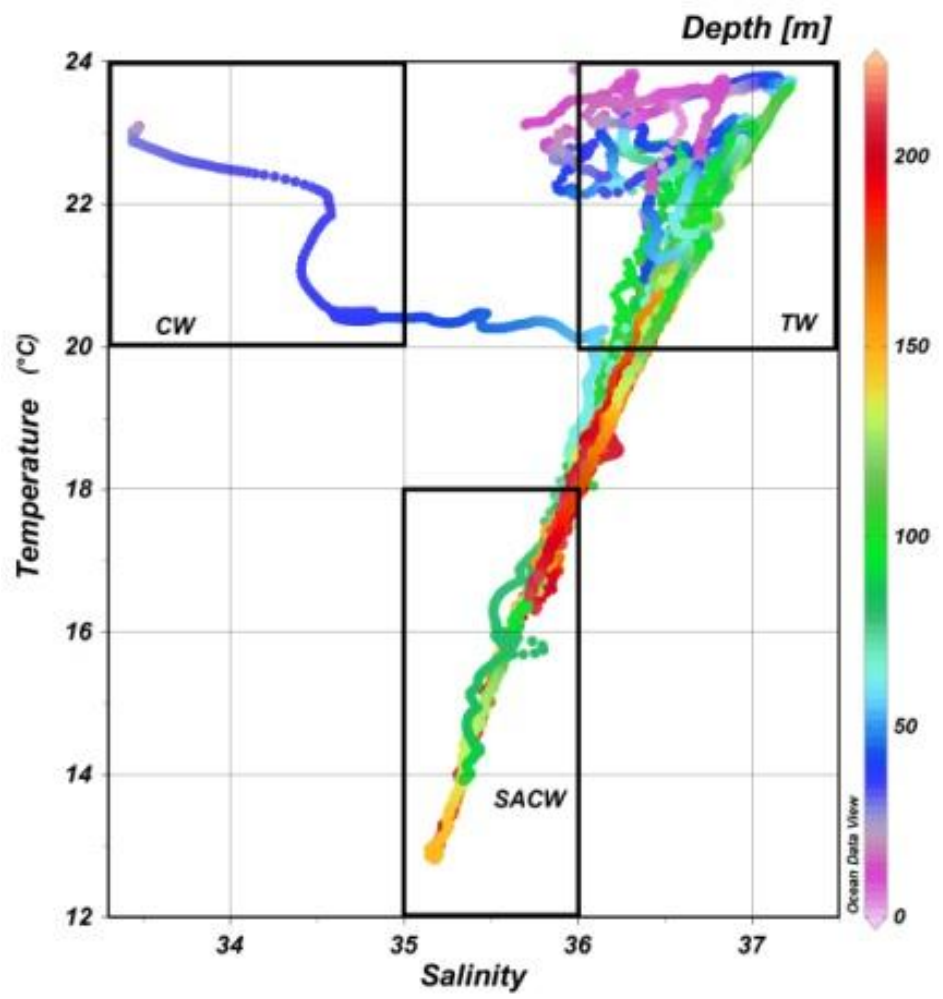

Figure S1. Temperature-Salinity (T-S) diagram generated with CTD dataset showing the water masses sampled in this study (open black boxes), with the depth on which they were found ( $Z$ axis, colorbar): Tropical Water (TW); South Atlantic Central Water (SACW) and Coastal Water (CW). 

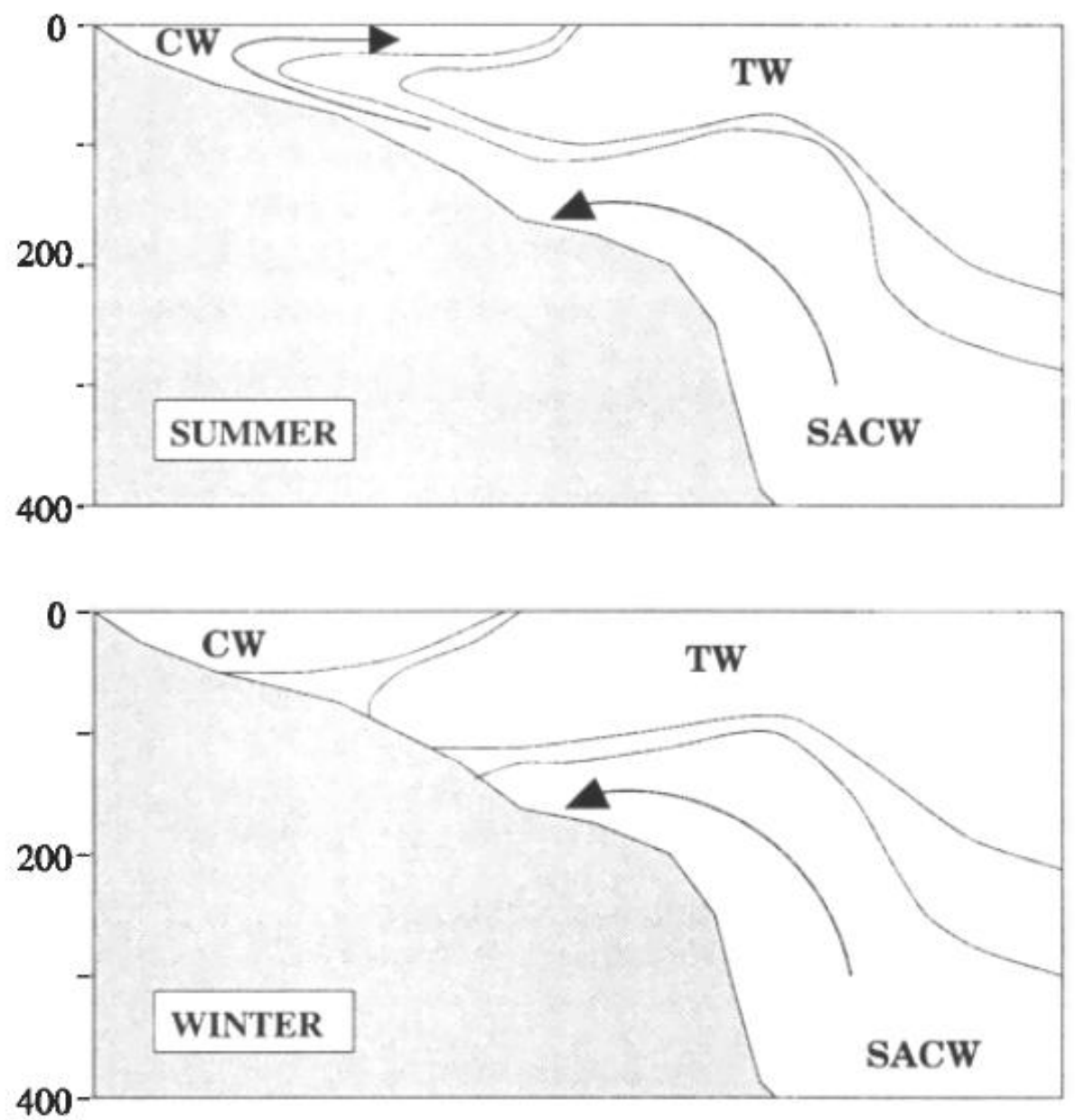

Figure S2. Representation of the seasonal intrusion of South Atlantic Central Water (SACW) over the bottom of the continental shelf, which is enhanced during summer, due to offshore Ekman transport of surface waters. CW: Coastal Water; TW: Tropical Water. Reprinted from (CAMPOS; VELHOTE; SILVEIRA, 2000). 
Table S1. Flow cytometry data for the different populations measured.

\begin{tabular}{|c|c|c|c|c|c|c|c|c|c|c|}
\hline Station & $\begin{array}{l}\text { Depth } \\
(\mathrm{m})\end{array}$ & Sample & $\begin{array}{l}\text { Bottom Depth } \\
(\mathrm{m})\end{array}$ & 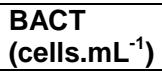 & $\begin{array}{l}\text { PRO } \\
\left.\text { (cells.mL } L^{-1}\right)\end{array}$ & $\begin{array}{l}\text { SYN } \\
\left(\text { cells.mL } \text { mL }^{-1}\right)\end{array}$ & $\begin{array}{l}\text { PEUK } \\
\left(\text { cells.mL } \mathrm{mL}^{-1}\right)\end{array}$ & $\begin{array}{l}\text { NEUK } \\
\left(\text { cells.mL }{ }^{-1} \text { ) }\right.\end{array}$ & $\begin{array}{l}\text { Total Biomass } \\
\left(\mu \mathrm{gC} . \mathrm{L}^{-1}\right)\end{array}$ & $\begin{array}{l}\text { Biomass } \\
\text { Het:Auto }\end{array}$ \\
\hline 81 & 5 & 39 & 2632 & 944895 & 173422 & 10270 & 725 & 2020 & 29.6 & 1.8 \\
\hline 81 & 30 & 41 & 2632 & 928357 & 184701 & 9961 & 525 & 2049 & 29.1 & 1.8 \\
\hline 81 & 80 & 43 & 2632 & 745237 & 261338 & 13363 & 583 & 1686 & 29.2 & 1.0 \\
\hline 81 & 140 & 45 & 2632 & 568090 & 188485 & 10078 & 2510 & 1505 & 27.2 & 0.7 \\
\hline 81 & 190 & 47 & 2632 & 372497 & 26328 & 623 & 1426 & 275 & 12.3 & 1.6 \\
\hline 85 & 5 & 49 & 2100 & 862294 & 43431 & 54789 & 686 & 1142 & 34.6 & 1.0 \\
\hline 85 & 70 & 51 & 2100 & 710229 & 72446 & 47260 & 377 & 1980 & 29.8 & 0.9 \\
\hline 85 & 110 & 53 & 2100 & 620778 & 101397 & 9446 & 4877 & 2515 & 31.1 & 0.7 \\
\hline 85 & 160 & 55 & 2100 & 466624 & 36951 & 784 & 1387 & 1436 & 14.5 & 1.8 \\
\hline 85 & 200 & 57 & 2100 & 519838 & 19270 & 9721 & 1578 & 799 & 17.7 & 1.4 \\
\hline 86 & 5 & 59 & 1739 & 845639 & 44861 & 35866 & 431 & 176 & 28.8 & 1.4 \\
\hline 86 & 70 & 61 & 1739 & 659083 & 144750 & 34509 & 926 & 1218 & 29.6 & 0.8 \\
\hline 86 & 105 & 63 & 1739 & 783348 & 45569 & 9241 & 2356 & 2037 & 25.8 & 1.6 \\
\hline 86 & 160 & 65 & 1739 & 342064 & 9269 & 255 & 213 & 384 & 7.8 & 7.2 \\
\hline 86 & 190 & 67 & 1739 & 226208 & 375 & 125 & 42 & 60 & 4.7 & 29.5 \\
\hline 87 & 5 & 69 & 1213 & 647815 & 89435 & 26620 & 468 & 398 & 24.2 & 1.2 \\
\hline 87 & 70 & 71 & 1213 & 663889 & 145028 & 27713 & 833 & 384 & 27.7 & 0.9 \\
\hline 87 & 105 & 73 & 1213 & 518805 & 47778 & 2060 & 2130 & 2037 & 18.1 & 1.3 \\
\hline 87 & 160 & 75 & 1213 & 267014 & 1069 & 111 & 37 & 139 & 5.5 & 32.8 \\
\hline 87 & 190 & 77 & 1213 & 183917 & 0 & 60 & 14 & 9 & 3.7 & 71.7 \\
\hline 88 & 5 & 79 & 850 & 639584 & 96833 & 34093 & 681 & 560 & 26.7 & 0.9 \\
\hline 88 & 30 & 81 & 850 & 803926 & 147907 & 46389 & 634 & 736 & 34.9 & 0.9 \\
\hline 88 & 50 & 83 & 850 & 859268 & 208815 & 23676 & 1718 & 1644 & 35.2 & 1.0 \\
\hline 88 & 80 & 85 & 850 & 1016709 & 43458 & 21449 & 8644 & 2264 & 49.8 & 0.7 \\
\hline 88 & 100 & 87 & 850 & 539602 & 18648 & 574 & 1718 & 801 & 16.1 & 2.0 \\
\hline
\end{tabular}


Table S1. Flow cytometry data for the different populations measured (continuation).

\begin{tabular}{|c|c|c|c|c|c|c|c|c|c|c|}
\hline Station & $\begin{array}{l}\text { Depth } \\
\text { (m) }\end{array}$ & Sample & $\begin{array}{l}\text { Bottom Depth } \\
\text { (m) }\end{array}$ & $\begin{array}{l}\text { BACT } \\
\text { (cells.mL } \text { mL }^{-1} \text { ) }\end{array}$ & $\begin{array}{l}\text { PRO } \\
\text { (cells.mL } \mathrm{mL}^{-1} \text { ) }\end{array}$ & $\begin{array}{l}\text { SYN } \\
\text { (cells.mL }{ }^{-1} \text { ) }\end{array}$ & $\begin{array}{l}\text { PEUK } \\
\text { (cells.mL }{ }^{-1} \text { ) }\end{array}$ & $\begin{array}{l}\text { NEUK } \\
\text { (cells.mL }{ }^{-1} \text { ) }\end{array}$ & $\begin{array}{l}\text { Total Biomass } \\
\left(\mu \mathrm{gC} \mathrm{L}^{-1}\right)\end{array}$ & $\begin{array}{l}\text { Biomass } \\
\text { Het:Auto }\end{array}$ \\
\hline 89 & 5 & 89 & 424 & 705995 & 101838 & 49986 & 745 & 736 & 32.5 & 0.8 \\
\hline 89 & 30 & 91 & 424 & 735861 & 102056 & 56278 & 1032 & 843 & 35.4 & 0.7 \\
\hline 89 & 70 & 93 & 424 & 674991 & 75509 & 9282 & 17542 & 4130 & 64.0 & 0.3 \\
\hline 89 & 95 & 95 & 424 & 511857 & 7310 & 528 & 690 & 995 & 12.4 & 4.7 \\
\hline 89 & 110 & 97 & 424 & 474166 & 1667 & 398 & 310 & 588 & 10.4 & 9.8 \\
\hline 90 & 5 & 99 & 235 & 593097 & 75153 & 30239 & 468 & 667 & 23.5 & 1.0 \\
\hline 90 & 30 & 102 & 235 & 632014 & 139486 & 20371 & 571 & 990 & 24.3 & 1.1 \\
\hline 90 & 60 & 103 & 235 & 518144 & 4023 & 644 & 1009 & 1982 & 13.3 & 3.5 \\
\hline 90 & 80 & 105 & 235 & 300577 & 423 & 284 & 221 & 419 & 6.7 & 9.1 \\
\hline 90 & 100 & 107 & 235 & 229430 & 153 & 248 & 108 & 86 & 4.9 & 13.2 \\
\hline 92 & 5 & 109 & 156 & 980804 & 103113 & 81374 & 1315 & 995 & 47.5 & 0.7 \\
\hline 92 & 30 & 111 & 156 & 1124318 & 140432 & 9360 & 18437 & 5153 & 77.7 & 0.4 \\
\hline 92 & 60 & 113 & 156 & 1057079 & 228671 & 22932 & 1239 & 1131 & 38.4 & 1.2 \\
\hline 92 & 80 & 115 & 156 & 640696 & 23554 & 3086 & 3698 & 2450 & 24.0 & 1.1 \\
\hline 92 & 100 & 117 & 156 & 453151 & 6599 & 1081 & 1095 & 1383 & 12.4 & 2.7 \\
\hline 96 & 5 & 120 & 111 & 1062014 & 193319 & 56132 & 877 & 1270 & 44.8 & 0.9 \\
\hline 96 & 30 & 121 & 111 & 995279 & 228554 & 64088 & 735 & 1598 & 46.4 & 0.8 \\
\hline 96 & 50 & 122 & 111 & 817319 & 130098 & 66578 & 975 & 1716 & 40.5 & 0.7 \\
\hline 96 & 80 & 123 & 111 & 505314 & 29353 & 770 & 328 & 941 & 12.2 & 4.8 \\
\hline 96 & 95 & 124 & 111 & 374348 & 3902 & 289 & 44 & 265 & 7.8 & 22.8 \\
\hline 98 & 5 & 125 & 265 & 742431 & 217152 & 31235 & 647 & 1377 & 32.3 & 0.9 \\
\hline 98 & 50 & 126 & 265 & 427755 & 228328 & 4441 & 49 & 1373 & 18.0 & 0.9 \\
\hline 98 & 85 & 127 & 265 & 370617 & 78716 & 1235 & 3466 & 490 & 19.5 & 0.6 \\
\hline 98 & 110 & 128 & 265 & 284731 & 14852 & 162 & 386 & 610 & 7.3 & 3.6 \\
\hline 98 & 125 & 129 & 265 & 315010 & 4407 & 255 & 877 & 373 & 8.8 & 2.5 \\
\hline 99 & 5 & 130 & 262 & 770991 & 170426 & 28858 & 814 & 951 & 31.0 & 1.0 \\
\hline 99 & 50 & 131 & 262 & 561776 & 290224 & 8357 & 286 & 943 & 24.6 & 0.8 \\
\hline 99 & 85 & 132 & 262 & 416715 & 100952 & 2805 & 2071 & 814 & 18.0 & 0.9 \\
\hline 99 & 115 & 133 & 262 & 293854 & 24729 & 262 & 1076 & 90 & 9.6 & 1.6 \\
\hline 99 & 140 & 134 & 262 & 219426 & 2824 & 57 & 210 & 38 & 5.0 & 6.7 \\
\hline
\end{tabular}


Table S1. Flow cytometry data for the different populations measured (continuation).

\begin{tabular}{|c|c|c|c|c|c|c|c|c|c|c|}
\hline Station & $\begin{array}{l}\text { Depth } \\
(\mathrm{m})\end{array}$ & Sample & $\begin{array}{l}\text { Bottom Depth } \\
(\mathrm{m})\end{array}$ & 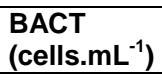 & $\begin{array}{l}\text { PRO } \\
\left(\text { cells.mL } \mathrm{mL}^{-1} \text { ) }\right.\end{array}$ & $\begin{array}{l}\text { SYN } \\
\text { (cells.mL } L^{-1} \text { ) }\end{array}$ & $\begin{array}{l}\text { PEUK } \\
\left(\text { cells.mL } \mathrm{mL}^{-1}\right)\end{array}$ & $\begin{array}{l}\text { NEUK } \\
\text { (cells.mL }^{-1} \text { ) }\end{array}$ & $\begin{array}{l}\text { Total Biomass } \\
\left(\mu \mathrm{gC} . \mathrm{L}^{-1}\right)\end{array}$ & $\begin{array}{l}\text { Biomass } \\
\text { Het:Auto }\end{array}$ \\
\hline 100 & 5 & 135 & 474 & 660426 & 126657 & 11343 & 738 & 448 & 22.6 & 1.4 \\
\hline 100 & 50 & 136 & 474 & 710766 & 215067 & 10214 & 495 & 519 & 25.8 & 1.2 \\
\hline 100 & 110 & 137 & 474 & 382650 & 121267 & 2729 & 2800 & 1933 & 20.0 & 0.6 \\
\hline 100 & 130 & 138 & 474 & 279928 & 20905 & 71 & 700 & 81 & 8.2 & 2.2 \\
\hline 100 & 170 & 139 & 474 & 233531 & 11719 & 329 & 86 & 352 & 5.4 & 6.4 \\
\hline 101 & 5 & 140 & 625 & 877857 & 8143 & 10838 & 819 & 724 & 22.7 & 3.4 \\
\hline 101 & 60 & 141 & 625 & 595198 & 290552 & 7524 & 243 & 876 & 24.9 & 0.9 \\
\hline 101 & 110 & 142 & 625 & 327002 & 29581 & 543 & 533 & 948 & 9.1 & 2.5 \\
\hline 101 & 130 & 143 & 625 & 312067 & 16100 & 95 & 148 & 619 & 7.2 & 6.3 \\
\hline 101 & 170 & 144 & 625 & 240138 & 1695 & 48 & 95 & 186 & 5.1 & 15.0 \\
\hline 102 & 5 & 145 & 887 & 792947 & 45886 & 8300 & 371 & 810 & 20.6 & 3.4 \\
\hline 102 & 65 & 146 & 887 & 685179 & 289738 & 8957 & 219 & 1329 & 27.0 & 1.0 \\
\hline 102 & 100 & 147 & 887 & 603196 & 194471 & 5981 & 695 & 1076 & 22.4 & 1.2 \\
\hline 102 & 150 & 148 & 887 & 357779 & 29971 & 1200 & 1067 & 381 & 11.3 & 1.7 \\
\hline 102 & 180 & 149 & 887 & 261738 & 262 & 52 & 33 & 33 & 5.3 & 48.0 \\
\hline 103 & 5 & 150 & 1300 & 910531 & 120219 & 7157 & 452 & 490 & 25.5 & 2.5 \\
\hline 103 & 65 & 151 & 1300 & 873133 & 252700 & 10210 & 600 & 462 & 30.7 & 1.3 \\
\hline 103 & 100 & 152 & 1300 & 577593 & 150824 & 7186 & 2386 & 695 & 25.0 & 0.9 \\
\hline 103 & 150 & 153 & 1300 & 462845 & 29905 & 1371 & 1100 & 157 & 13.5 & 2.2 \\
\hline 103 & 180 & 154 & 1300 & 432431 & 10152 & 652 & 471 & 138 & 10.4 & 4.9 \\
\hline 106 & 5 & 155 & 2425 & 758346 & 119571 & 6181 & 681 & 510 & 22.8 & 2.0 \\
\hline 106 & 60 & 156 & 2425 & 743247 & 180086 & 8352 & 610 & 762 & 25.1 & 1.5 \\
\hline 106 & 100 & 157 & 2425 & 454190 & 226810 & 8186 & 4029 & 1790 & 29.8 & 0.4 \\
\hline 106 & 130 & 158 & 2425 & 368510 & 26490 & 1071 & 586 & 1710 & 10.1 & 2.7 \\
\hline 106 & 190 & 159 & 2425 & 311124 & 876 & 62 & 14 & 176 & 6.3 & 73.8 \\
\hline 110 & 5 & 160 & 2991 & 773486 & 210681 & 6733 & 200 & 957 & 25.3 & 1.6 \\
\hline 110 & 50 & 161 & 2991 & 717757 & 239243 & 13724 & 519 & 1119 & 27.8 & 1.1 \\
\hline 110 & 90 & 162 & 2991 & 365212 & 65705 & 1433 & 1033 & 1476 & 12.7 & 1.4 \\
\hline 110 & 140 & 163 & 2991 & 322290 & 9210 & 524 & 338 & 262 & 7.8 & 4.8 \\
\hline 110 & 170 & 164 & 2991 & 336660 & 9257 & 471 & 186 & 481 & 7.7 & 7.2 \\
\hline
\end{tabular}


Table S1. Flow cytometry data for the different populations measured (continuation).

\begin{tabular}{|c|c|c|c|c|c|c|c|c|c|c|}
\hline Station & $\begin{array}{l}\text { Depth } \\
\text { (m) }\end{array}$ & Sample & $\begin{array}{l}\text { Bottom Depth } \\
\text { (m) }\end{array}$ & $\begin{array}{l}\text { BACT } \\
{\text { (cells. } \mathrm{mL}^{-1} \text { ) }}\end{array}$ & $\begin{array}{l}\text { PRO } \\
\text { (cells. } \mathrm{mL}^{-1} \text { ) }\end{array}$ & $\begin{array}{l}\text { SYN } \\
\text { (cells.mL } \mathrm{mL}^{-1} \text { ) }\end{array}$ & $\begin{array}{l}\text { PEUK } \\
\left(\text { cells.mL }{ }^{-1} \text { ) }\right.\end{array}$ & $\begin{array}{l}\text { NEUK } \\
\text { (cells.mL }^{-1} \text { ) }\end{array}$ & $\begin{array}{l}\text { Total Biomass } \\
\left(\mu \mathrm{gC} . \mathrm{L}^{-1}\right)\end{array}$ & $\begin{array}{l}\text { Biomass } \\
\text { Het:Auto }\end{array}$ \\
\hline 110 & 5 & 160 & 2991 & 773486 & 210681 & 6733 & 200 & 957 & 25.3 & 1.6 \\
\hline 110 & 50 & 161 & 2991 & 717757 & 239243 & 13724 & 519 & 1119 & 27.8 & 1.1 \\
\hline 110 & 90 & 162 & 2991 & 365212 & 65705 & 1433 & 1033 & 1476 & 12.7 & 1.4 \\
\hline 110 & 140 & 163 & 2991 & 322290 & 9210 & 524 & 338 & 262 & 7.8 & 4.8 \\
\hline 110 & 170 & 164 & 2991 & 336660 & 9257 & 471 & 186 & 481 & 7.7 & 7.2 \\
\hline 114 & 5 & 165 & 3509 & 694824 & 90176 & 7033 & 305 & 333 & 19.7 & 2.4 \\
\hline 114 & 60 & 166 & 3509 & 670259 & 213824 & 8948 & 310 & 467 & 24.2 & 1.2 \\
\hline 114 & 80 & 167 & 3509 & 702714 & 227619 & 10905 & 748 & 305 & 27.0 & 1.1 \\
\hline 114 & 100 & 168 & 3509 & 551179 & 178238 & 14019 & 4562 & 557 & 32.8 & 0.5 \\
\hline 114 & 160 & 169 & 3509 & 378243 & 16424 & 662 & 776 & 186 & 10.3 & 2.7 \\
\hline 133 & 5 & 170 & 86 & 1420007 & 93410 & 39262 & 2314 & 1019 & 47.8 & 1.5 \\
\hline 134 & 5 & 171 & 124 & 1104273 & 186310 & 27076 & 619 & 900 & 37.3 & 1.5 \\
\hline 136 & 5 & 175 & 185 & 1247198 & 159219 & 13243 & 533 & 686 & 35.4 & 2.4 \\
\hline 137 & 5 & 177 & 229 & 1203743 & 144590 & 12990 & 533 & 776 & 34.0 & 2.4 \\
\hline 138 & 5 & 179 & 315 & 1074900 & 221933 & 17171 & 943 & 738 & 36.3 & 1.5 \\
\hline 139 & 5 & 181 & 398 & 1060343 & 200990 & 16681 & 919 & 838 & 35.1 & 1.5 \\
\hline 140 & 5 & 183 & 551 & 1069619 & 266214 & 18943 & 967 & 952 & 38.3 & 1.3 \\
\hline 141 & 5 & 185 & 810 & 1047116 & 216467 & 17062 & 1086 & 957 & 35.9 & 1.4 \\
\hline 142 & 5 & 187 & 1390 & 688907 & 254510 & 12771 & 948 & 1062 & 28.7 & 0.9 \\
\hline 143 & 5 & 189 & 1938 & 826031 & 140886 & 12452 & 781 & 643 & 26.8 & 1.6 \\
\hline 145 & 5 & 191 & 3180 & 822805 & 126195 & 8048 & 533 & 519 & 24.4 & 2.1 \\
\hline 147 & 5 & 193 & 3199 & 864779 & 46638 & 12257 & 1105 & 357 & 25.0 & 2.3 \\
\hline TRICHO & surf & TRICHO & 625 & 3004771 & 62 & 335205 & 767 & 1105 & 147.6 & 0.7 \\
\hline
\end{tabular}


Table S2. Phylogenetic assignation of plastid 16S rRNA gene sequences.

\begin{tabular}{|c|c|c|c|c|c|c|}
\hline Station & Depth & Size & Clone & $\begin{array}{l}\text { BLAST } \\
\text { accession }\end{array}$ & $\begin{array}{l}\text { BLAST } \\
\text { ID (\%) }\end{array}$ & BLAST Description \\
\hline St.98 & surf. & NEUK & A2 & HM133418 & 100 & Uncultured marine haptophyte clone Biosope_T65_16S.36a 16S ribosomal RNA gene, partial sequence; plastid \\
\hline St.98 & surf. & NEUK & A6 & HM133418 & 100 & Uncultured marine haptophyte clone Biosope_T65_16S.36a 16S ribosomal RNA gene, partial sequence; plastid \\
\hline St.98 & surf. & NEUK & A7 & HM133414 & 99.9 & Uncultured marine haptophyte clone Biosope_T65_16S.32b 16S ribosomal RNA gene, partial sequence; plastid \\
\hline St.98 & surf. & PEUK & B5 & EF052039 & 96.5 & Uncultured haptophyte clone 250304-42 16S ribosomal RNA gene, partial sequence; plastid \\
\hline St.98 & surf. & NEUK & B7 & HM133414 & 99.9 & Uncultured marine haptophyte clone Biosope_T65_16S.32b 16S ribosomal RNA gene, partial sequence; plastid \\
\hline St.98 & surf. & NEUK & C2 & HM133324 & 99 & Uncultured marine haptophyte clone Biosope_T58_16S_PLA491.010 16S ribosomal RNA gene, partial sequence; plastid \\
\hline St.98 & surf. & NEUK & C7 & EF051989 & 98.5 & Uncultured haptophyte clone MAMA64-128 16S ribosomal RNA gene, partial sequence; plastid \\
\hline St.98 & surf. & NEUK & D6 & HM133414 & 99.2 & Uncultured marine haptophyte clone Biosope_T65_16S.32b 16S ribosomal RNA gene, partial sequence; plastid \\
\hline St.98 & surf. & NEUK & D7 & HM133418 & 99.9 & Uncultured marine haptophyte clone Biosope_T65_16S.36a 16S ribosomal RNA gene, partial sequence; plastid \\
\hline St.98 & surf. & NEUK & E2 & HM133420 & 99 & Uncultured marine haptophyte clone Biosope_T65_16S.38a 16S ribosomal RNA gene, partial sequence; plastid \\
\hline St.98 & surf. & PEUK & E5 & LN735407.3 & 98 & Emiliania huxleyi chloroplast partial 16S rRNA gene, strain RCC 2941 \\
\hline St.98 & surf. & PEUK & F4 & HM133259 & 99.8 & Uncultured marine chrysophyte clone Biosope_T41_16S_PLA491.033 16S ribosomal RNA gene, partial sequence; plastid \\
\hline St.98 & surf. & PEUK & F6 & HM133354 & 99 & Uncultured marine dictyochophyte clone Biosope_T60_16S_OXY107.022 16S ribosomal RNA gene, partial sequence; plastid \\
\hline St.98 & surf. & NEUK & F7 & HM133420 & 100 & Uncultured marine haptophyte clone Biosope_T65_16S.38a 16S ribosomal RNA gene, partial sequence; plastid \\
\hline St.98 & surf. & NEUK & G2 & HM133420 & 100 & Uncultured marine haptophyte clone Biosope_T65_16S.38a 16S ribosomal RNA gene, partial sequence; plastid \\
\hline St.98 & surf. & PEUK & G4 & HM133344 & 99 & Uncultured marine chrysophyte clone Biosope_T60_16S_OXY107.005 16S ribosomal RNA gene, partial sequence; plastid \\
\hline St.98 & surf. & NEUK & G6 & LN735285 & 100 & Dictyochophyceae sp. RCC1727 chloroplast partial 16S rRNA gene, strain RCC 1727 \\
\hline St.98 & surf. & NEUK & G7 & HM133420 & 100 & Uncultured marine haptophyte clone Biosope_T65_16S.38a 16S ribosomal RNA gene, partial sequence; plastid \\
\hline St.98 & surf. & NEUK & $\mathrm{H} 1$ & HM133420 & 100 & Uncultured marine haptophyte clone Biosope_T65_16S.38a 16S ribosomal RNA gene, partial sequence; plastid \\
\hline St.98 & surf. & PEUK & $\mathrm{H} 4$ & HM133420 & 100 & Uncultured marine haptophyte clone Biosope_T65_16S.38a 16S ribosomal RNA gene, partial sequence; plastid \\
\hline St.98 & surf. & NEUK & H5 & HM133420 & 100 & Uncultured marine haptophyte clone Biosope_T65_16S.38a 16S ribosomal RNA gene, partial sequence; plastid \\
\hline St.98 & surf. & NEUK & $\mathrm{H} 6$ & EF052028 & 98.9 & Uncultured haptophyte clone 250304-29 16S ribosomal RNA gene, partial sequence; plastid \\
\hline St.98 & surf. & NEUK & $\mathrm{H} 7$ & HM133420 & 100 & Uncultured marine haptophyte clone Biosope_T65_16S.38a 16S ribosomal RNA gene, partial sequence; plastid \\
\hline St.106 & $60 \mathrm{~m}$ & PEUK & A8 & HM133420 & 100 & Uncultured marine haptophyte clone Biosope_T65_16S.38a 16S ribosomal RNA gene, partial sequence; plastid \\
\hline St.106 & $60 \mathrm{~m}$ & PEUK & B3 & HM133420 & 100 & Uncultured marine haptophyte clone Biosope_T65_16S.38a 16S ribosomal RNA gene, partial sequence; plastid \\
\hline St.106 & $60 \mathrm{~m}$ & PEUK & B8 & HM133420 & 100 & Uncultured marine haptophyte clone Biosope_T65_16S.38a 16S ribosomal RNA gene, partial sequence; plastid \\
\hline St.106 & $60 \mathrm{~m}$ & PEUK & C3 & HM133420 & 100 & Uncultured marine haptophyte clone Biosope_T65_16S.38a 16S ribosomal RNA gene, partial sequence; plastid \\
\hline St.106 & $60 \mathrm{~m}$ & PEUK & D3 & HM133420 & 100 & Uncultured marine haptophyte clone Biosope_T65_16S.38a 16S ribosomal RNA gene, partial sequence; plastid \\
\hline St.TRICHO & surf. & PEUK & B1 & HM133420 & 100 & Uncultured marine haptophyte clone Biosope_T65_16S.38a 16S ribosomal RNA gene, partial sequence; plastid \\
\hline St.TRICHO & surf. & NEUK & E4 & HM133420 & 100 & Uncultured marine haptophyte clone Biosope_T65_16S.38a 16S ribosomal RNA gene, partial sequence; plastid \\
\hline
\end{tabular}


Table S2. Phylogenetic assignation of plastid 16S rRNA gene sequences.

\begin{tabular}{|c|c|c|c|c|c|c|c|}
\hline Station & Depth & Size & Clone & Division & & & \\
\hline St.98 & surface & NEUK & A2 & Haptophyta & Prymnesiophyceae & Braarudosphaeraceae & Braarudosphaera \\
\hline St.98 & surface & NEUK & A6 & Haptophyta & Prymnesiophyceae & Braarudosphaeraceae & Braarudosphaera \\
\hline St.98 & surface & NEUK & A7 & Haptophyta & Prymnesiophyceae & Braarudosphaeraceae & Braarudosphaera \\
\hline St.98 & surface & PEUK & B5 & Haptophyta & Prymnesiophyceae & Noelaerhabdaceae & Emiliania \\
\hline St.98 & surface & NEUK & B7 & Haptophyta & Prymnesiophyceae & Braarudosphaeraceae & Braarudosphaera \\
\hline St.98 & surface & NEUK & $\mathrm{C} 2$ & Haptophyta & Prymnesiophyceae & Chrysochromulinaceae & Chrysochromulinaceae_X \\
\hline St.98 & surface & NEUK & $\mathrm{C} 7$ & Haptophyta & Prymnesiophyceae & Chrysochromulinaceae & Chrysochromulinaceae_X \\
\hline St.98 & surface & NEUK & D6 & Haptophyta & Prymnesiophyceae & Braarudosphaeraceae & Braarudosphaera \\
\hline St.98 & surface & NEUK & $\mathrm{D} 7$ & Haptophyta & Prymnesiophyceae & Braarudosphaeraceae & Braarudosphaera \\
\hline St.98 & surface & NEUK & E2 & Haptophyta & Prymnesiophyceae & Braarudosphaeraceae & Braarudosphaera \\
\hline St.98 & surface & PEUK & E5 & Haptophyta & Prymnesiophyceae & Noelaerhabdaceae & Emiliania \\
\hline St.98 & surface & PEUK & $\mathrm{F} 4$ & Ochrophyta & Chrysophyceae-Synurophyceae & Chrysophyceae-Synurophyceae & Chrysophyceae-Synurophyceae \\
\hline St.98 & surface & PEUK & F6 & Ochrophyta & Dictyochophyceae & Florenciellales_XX & Florenciellales_XXX \\
\hline St.98 & surface & NEUK & $\mathrm{F} 7$ & Haptophyta & Prymnesiophyceae & Braarudosphaeraceae & Braarudosphaera \\
\hline St.98 & surface & NEUK & G2 & Haptophyta & Prymnesiophyceae & Braarudosphaeraceae & Braarudosphaera \\
\hline St.98 & surface & PEUK & G4 & Ochrophyta & Chrysophyceae & Chrysophyceae_XXXX & Chrysophyceae_XXXXX \\
\hline St.98 & surface & NEUK & G6 & Ochrophyta & Dictyochophyceae & Dictyochophyceae_XXXX & Dictyochophyceae_XXXXX \\
\hline St.98 & surface & NEUK & G7 & Haptophyta & Prymnesiophyceae & Braarudosphaeraceae & Braarudosphaera \\
\hline St.98 & surface & NEUK & $\mathrm{H} 1$ & Haptophyta & Prymnesiophyceae & Braarudosphaeraceae & Braarudosphaera \\
\hline St.98 & surface & PEUK & $\mathrm{H} 4$ & Haptophyta & Prymnesiophyceae & Braarudosphaeraceae & Braarudosphaera \\
\hline St.98 & surface & NEUK & $\mathrm{H} 5$ & Haptophyta & Prymnesiophyceae & Braarudosphaeraceae & Braarudosphaera \\
\hline St.98 & surface & NEUK & $\mathrm{H} 6$ & Haptophyta & Prymnesiophyceae & Chrysochromulinaceae & Chrysochromulinaceae_X \\
\hline St.98 & surface & NEUK & $\mathrm{H} 7$ & Haptophyta & Prymnesiophyceae & Braarudosphaeraceae & Braarudosphaera \\
\hline St.106 & $60 \mathrm{~m}$ & PEUK & A8 & Haptophyta & Prymnesiophyceae & Braarudosphaeraceae & Braarudosphaera \\
\hline St.106 & $60 \mathrm{~m}$ & PEUK & B3 & Haptophyta & Prymnesiophyceae & Braarudosphaeraceae & Braarudosphaera \\
\hline St.106 & $60 \mathrm{~m}$ & PEUK & B8 & Haptophyta & Prymnesiophyceae & Braarudosphaeraceae & Braarudosphaera \\
\hline St.106 & $60 \mathrm{~m}$ & PEUK & $\mathrm{C} 3$ & Haptophyta & Prymnesiophyceae & Braarudosphaeraceae & Braarudosphaera \\
\hline St.106 & $60 \mathrm{~m}$ & PEUK & D3 & Haptophyta & Prymnesiophyceae & Braarudosphaeraceae & Braarudosphaera \\
\hline St.TRICHO & surface & PEUK & B1 & Haptophyta & Prymnesiophyceae & Braarudosphaeraceae & Braarudosphaera \\
\hline St.TRICHO & surface & NEUK & E4 & Haptophyta & Prymnesiophyceae & Braarudosphaeraceae & Braarudosphaera \\
\hline
\end{tabular}




\section{CHAPTER 2}

Quantitative analysis of the picoplanktonic community in two functionally distinct blooms in the southwest subtropical Atlantic Ocean:

Trichodesmium spp. and Mesodinium rubrum 


\section{RESUMO}

A cianobactéria Trichodesmium spp. está presente em águas superficiais dos oceanos tropicais e subtropicais, é capaz de formar extensas florações, sendo considerada um dos mais importantes grupos diazotróficos em ecossistemas marinhos oligotróficos. O ciliado mixotrófico Mesodinium rubrum é ubíquo em comunidades planctônicas costeiras, e pode formar florações massivas, que geralmente são efêmeras, não tóxicas, e associadas a altas taxas de produtividade primária. Nós utilizamos a citometria de fluxo para investigar a influência destas duas florações (Trichodesmium spp. and Mesodinium rubrum) na abundância e biomassa do picoplâncton no sudoeste do oceano Atlântico, ao largo do Brasil. Foram observadas altas abundâncias de bactérias heterotróficas e Synechococcus na floração de Trichodesmium spp, porém nenhum efeito na abundância de pico- e nanoplâncton. Quanto à floração de $M$. rubrum, a alta biomassa de bactérias heterotróficas e Synechococcus indica que estas populações podem ter auxiliado na proliferação do ciliado. Eucariotos contendo ficoeritrina (presumidamente Cryptofíceas) foram detectadas em concentrações variáves na floração de $M$. rubrum e imediações, mas estavam ausentes nas amostras da floração de Trichodesmium. No melhor de nosso conhecimento, esta é a primeira descrição por citometria de fluxo da comunidade pico- e nanoplanctônica em uma floração de $M$. rubrum, o que ajudará a elucidar o impacto deste tipo de floração nas comunidades planctônicas próximas.

Palavras-chave: citometria de fluxo, Trichodesmium spp., Mesodinium rubrum; bactérias heterotróficas, Prochlorococcus, Synechococcus, picoeucariotos, nanoeucariotos. 


\section{ABSTRACT}

Trichodesmium spp. is a bloom-forming cyanobacteria present in surface waters of the tropical and subtropical oceans, which has been considered one the most important diazotrophic groups in oligotrophic marine ecosystems. The mixotrophic ciliate Mesodinium rubrum is ubiquitous in coastal planktonic communities and can form massive blooms, which are generally ephemeral, non-toxic and associated with high rates of primary production. We used flow cytometry in order to investigate the influence of two distinct blooms (Trichodesmium spp. and Mesodinium rubrum) on the abundance and carbon biomass of picoplankton in the Southwest Atlantic ocean off Brazil. High HNA/LNA bacterial and Synechococcus abundance was observed in the Trichodesmium bloom, and no effect in the pico- and nanoeukaryotic abundance. Regarding M. rubrum, the high HNA/LNA and Synechococcus biomass indicate that these populations might have fueled the mixotrophic ciliate proliferation. Phycoerythrin-containing eukaryotes (presumably Cryptophyta) were detected in variable concentrations in the M. rubrum bloom, but were absent near and inside the Trichodesmium spp. bloom. To the best of our knowledge, this is the first description by flow cytometry of the picoplankton community inside a Mesodinium rubrum bloom, which will help to elucidate its impact in the surrounding planktonic community.

Keywords: flow cytometry, Trichodesmium spp., Mesodinium rubrum, heterotrophic bacteria, Prochlorococcus, Synechococcus, picoeukaryotes, nanoeukaryotes. 


\subsection{INTRODUCTION}

The debate around the raise of atmospheric $\mathrm{CO}_{2}$ and its implications for the global climate have fueled a new interest on the characterization of oceanic primary productivity and the carbon removal rate to the deep ocean. Climate variations can have a powerful influence on the oceanic biogeochemical cycles modifying the stratification patterns, light field and temperature distribution in the euphotic zone. Potentially, there can be a possible direct feedback to the climate via carbon dioxide sequestration (COLES et al., 2004). Phytoplanktonic blooms can have a great impact on the biogeochemical fluxes, in the surrounding plankton community and on the ocean-atmosphere thermal energy exchange (DETONI et al., 2016; HERFORT et al., 2012; JOLLIFF et al., 2012) (Figure 2.1). Biological productivity in the oceans is, at a great extension, limited by nitrogen availability (MOORE et al., 2013). Trichodesmium spp. is one the most important diazotroph in oligotrophic marine ecosystems (CAPONE, 1997; FERNÁNDEZ et al., 2010; KARL et al., 1997), being particularly abundant in surface layers of the tropical and subtropical gyres and tropical latitudes of western boundary currents (CAPONE, 1997). It is filamentous, polymorphic, and can exist as free trichomes (single filaments of cells) or in fusiform (tuft) and spherical (puff) colonies. The estimated rate of new nitrogen production by these organisms is around 80-110 Tg.year $^{-1}$ in oligotrophic waters (DAVIS; MCGILLICUDDY, 2006), corresponding to $1 / 4$ of annual nitrogen fixation in the oceans (NAUSCH, 1996). 
Previous studies reported the occurrence and description of Trichodesmium spp. blooms throughout the Brazilian coast and their correlation with potential toxicological parameters (CARVALHO; GIANESELLA; SALDANHA-CORRÊA, 2008; DETONI et al., 2016; MAFRA JUNIOR; FERNANDES; PROENÇA, 2006; SIQUEIRA; KOLM; BRANDINI, 2006). However, this is the first time that the influence of such blooms in the pico- and nanoplanktonic community is investigated in the region.

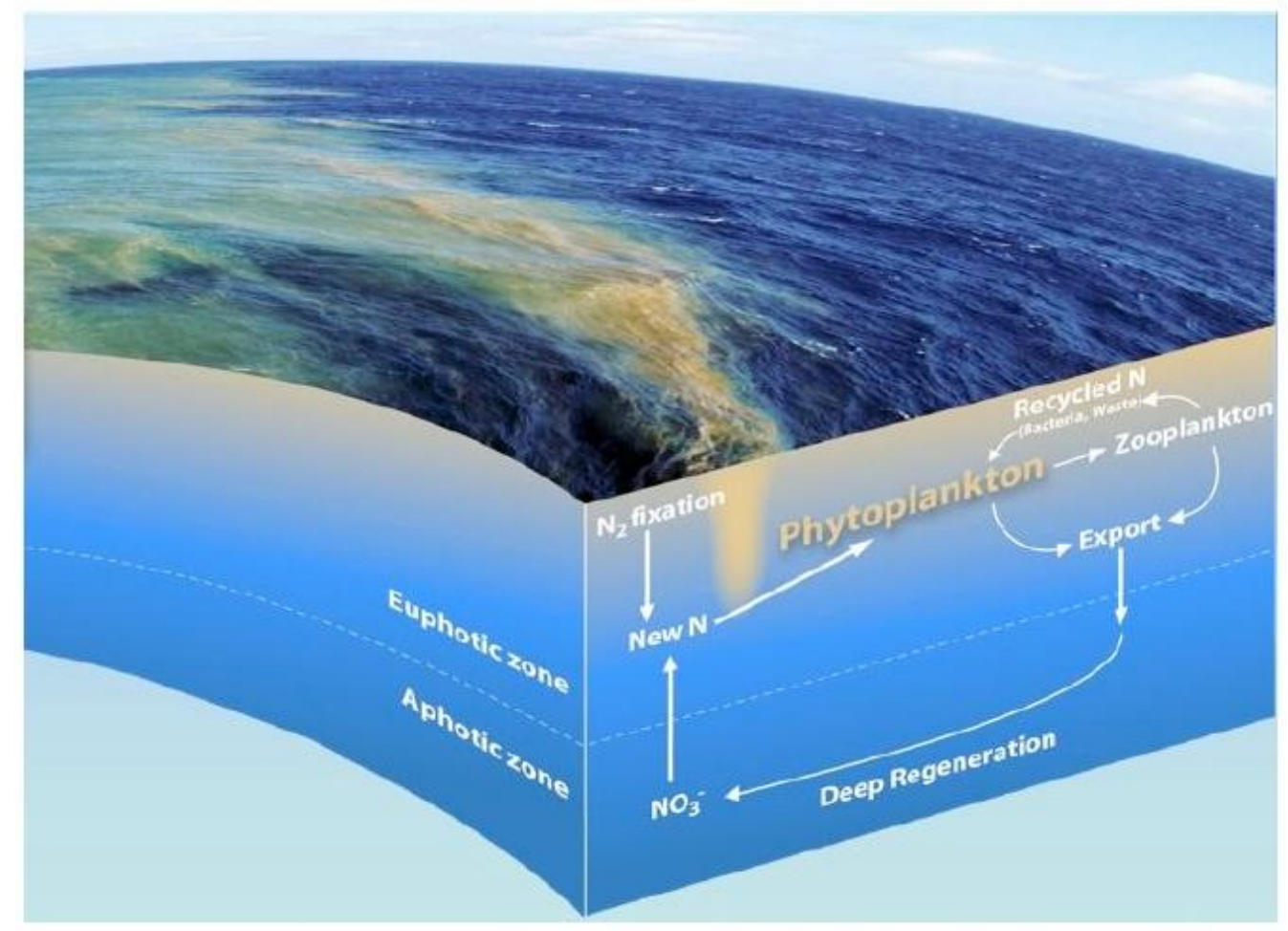

Figure 2.1. Schematic model of the impact of a Trichodesmium spp. bloom in the water column community (reproduced from Hynes et al., (2009). 
Trichodesmium spp. studies in oligotrophic, oceanic regions had provided data about this genus in the South Atlantic Ocean. Fernández et al., (2010) and Tyrrell et al., (2003) determined Trichodesmium spp. abundance on a latitudinal transect, as well as nitrogen fixation data. Westberry \& Siegel, (2006) used ocean color data to estimate spatial distribution and temporal dynamics of Trichodesmium spp. blooms in global oceans. Trichodesmium spp. blooms release organic compounds to the water column such as newly fixed dissolved organic nitrogen, photosynthetic exudates and organic matter as mucilage, formed by a carboxylated polysaccharide (transparent exopolymeric particles) (BERMAN-FRANK et al., 2007; CARPENTER; CAPONE, 1992; GLIBERT; BRONK, 1994; MULHOLLAND; BERNHARDT, 2005). The photosynthetic ciliate Mesodinium rubrum (Lohmann 1908) Jankowski 1976 (=Myrionecta rubra) is ubiquitous in planktonic communities, bearing in phycoerythrin-rich plastids, and capable of massive blooms (JOHNSON; STOECKER; MARSHALL, 2013; JUEL HANSEN; FENCHEL, 2006). Red tides caused by $M$. rubrum are generally ephemeral and non-toxic, associated with high rates of primary production in coastal environments (CRAWFORD, 1989; GUSTAFSON et al., 2000). The occurrence of $M$. rubrum blooms is attributed to the water column stability (KYEWALYANGA; SATHYENDRANATH; PLATT, 2002), as well as to the input of nutrients through upwelling or estuarine plumes enrichments (JOHNSON; STOECKER; MARSHALL, 2013). M. rubrum can assimilate ammonium, nitrate, amino acids, dissolved organic carbon and nitrogen, powerfully impacting biogeochemical cycles where dense blooms develop, due to an enhanced release of dissolved organic matter (HERFORT et al., 2012 and references therein). The high rate of $\mathrm{CO}_{2}$ assimilation of these 
organisms, their capability to grow at high cell densities and to tolerate wide variations in salinity and temperature, makes them a suitable target for marine biotechnological applications (YIH; SHIM, 1997).

There can be a wide vertical migration inside $M$. rubrum blooms, driven by light, nutrients and tidal stirring (CRAWFORD, 1989; JOHNSON; STOECKER; MARSHALL, 2013). However, there are also reports of populations standing in the deep chlorophyll maximum throughout the circadian cycle (PÉREZ et al., 1999). Reports of $M$. rubrum in the studied region registered abundances between 130 cells. $\mathrm{mL}^{-1}$ and 4,400 cells. $\mathrm{mL}^{-1}$ (PAULO C. ABREU; BOPAIAH B. BIDDANDA; CLARISSE ODEBRECHT, 1992; PROENÇA, 2004).

In this study we addressed the effect of two distinct bloom-forming planktonic organisms, the autotrophic cyanobacterium Trichodesmium spp. and the mixotrophic ciliate Mesodinium rubrum, on the abundance and biomass of the nearby pico- and nanoplankton. To the best of our knowledge, this is the first description by flow cytometry of the picoplankton community inside a Mesodinium rubrum bloom, which will help to elucidate its impact in the surrounding planktonic community. 


\subsection{OBJECTIVES}

- To determine the abundance and biomass of heterotrophic bacteria and autotrophic pico- and nanoplankton in two functionally distinct blooms (Trichodesmium spp. and Mesodinium rubrum).

- To investigate the influence of the blooms on dominance patterns regarding picoplanktonic abundance and carbon biomass in surrounding waters. 


\subsection{MATERIAL AND METHODS}

\subsubsection{Trichodesmium spp. bloom}

Samples were collected onboard of the research vessel "Alpha Crucis", during the cruise CARBOM V, in 18/11/2013, between latitude $27^{\circ} 42^{\prime} 30^{\prime \prime S}$ $27^{\circ} 48^{\prime} 50^{\prime \prime S}$ and longitudes $47^{\circ} 06^{\prime} 37^{\prime \prime} \mathrm{W}-47^{\circ} 08^{\prime} 43^{\prime \prime} \mathrm{W}$, and between the isobaths of 474 meters and 625 meters depth (Figure 2.2, Table 2.1). Stations T100 and T101 (a, b, c and d) were collected a with $12 \mathrm{~L}$ Niskin bottles attached to a Seabird $^{\circledR}$ CTD-rosette system (Sea-Bird Electronics, Bellevue, WA, USA) (see Chapter 01 Material and Methods section for further information). The superficial sample TRICHO was collected using a polycarbonate bucket. Samples were divided into cryotubes, preserved with $0.1 \%$ glutaraldehyde (final concentration), kept incubating for 10 minutes in the dark, flash-frozen in liquid nitrogen and stored at $-80^{\circ} \mathrm{C}$ until analysis.

Flow cytometry analysis were performed in a BD FACSCanto ${ }^{\mathrm{TM}}$ flow cytometer. The details of the procedures for flow cytometry, as well as biomass conversion, cell sorting and clone library sequencing can be found in the Material and Methods section from Chapter 01. 


\subsubsection{Mesodinium rubrum bloom}

Samples were collected onboard the R/V 'Antares' between latitude $23^{\circ} 59^{\prime} \mathrm{S}-24^{\circ} 35^{\prime} \mathrm{S}$ and longitude $44^{\circ} 33^{\prime} \mathrm{W}-45^{\circ} 14^{\prime} \mathrm{W}$ (Figure 2.2, Table 2.1), in july/2014, during a massive bloom which covered a large area of South Atlantic ocean off Brazil (Figure 2.3 - B). Flow cytometry samples were collected with a 2-L Van Dorn bottle, divided into cryotubes, preserved with $0.1 \%$ glutaraldehyde (final concentration), kept incubating for 10 minutes in the dark, flash-frozen in liquid nitrogen and stored at $-80^{\circ} \mathrm{C}$ until analysis. Details on flow cytometry analysis and biomass conversion can be found in the Material and Methods section from Chapter 01. 
Table 2.1. List of stations, samples and depths from the Trichodesmium spp. and $M$. rubrum cruise.

\begin{tabular}{llr}
\hline Station & Sample & Prof. (m) \\
\hline T100 & TRICHO & surface \\
(right above the bloom) & a & 5 \\
& b & 50 \\
& C & 110 \\
& d & 130 \\
& e & 170 \\
\hline T101 & a & 5 \\
& b & 60 \\
& C & 110 \\
& d & 130 \\
& e & 170 \\
\hline St. M1 & MR 1 & 4 \\
(right above the bloom) & MR 3 & 0 \\
& MR 4 & 5 \\
& MR 5 & 10 \\
& MR 6 & 30 \\
\hline St. M5 & MR 7 & 0 \\
& MR 8 & 30 \\
& MR 9 & 60 \\
\hline St. M7 & MR 10 & 0 \\
& MR 11 & 7.5 \\
& MR 12 & 30 \\
\hline St. M9 & MR 13 & 0 \\
& MR 14 & 30 \\
\hline & MR 15 & \\
& & 20 \\
& & \\
& & \\
& &
\end{tabular}




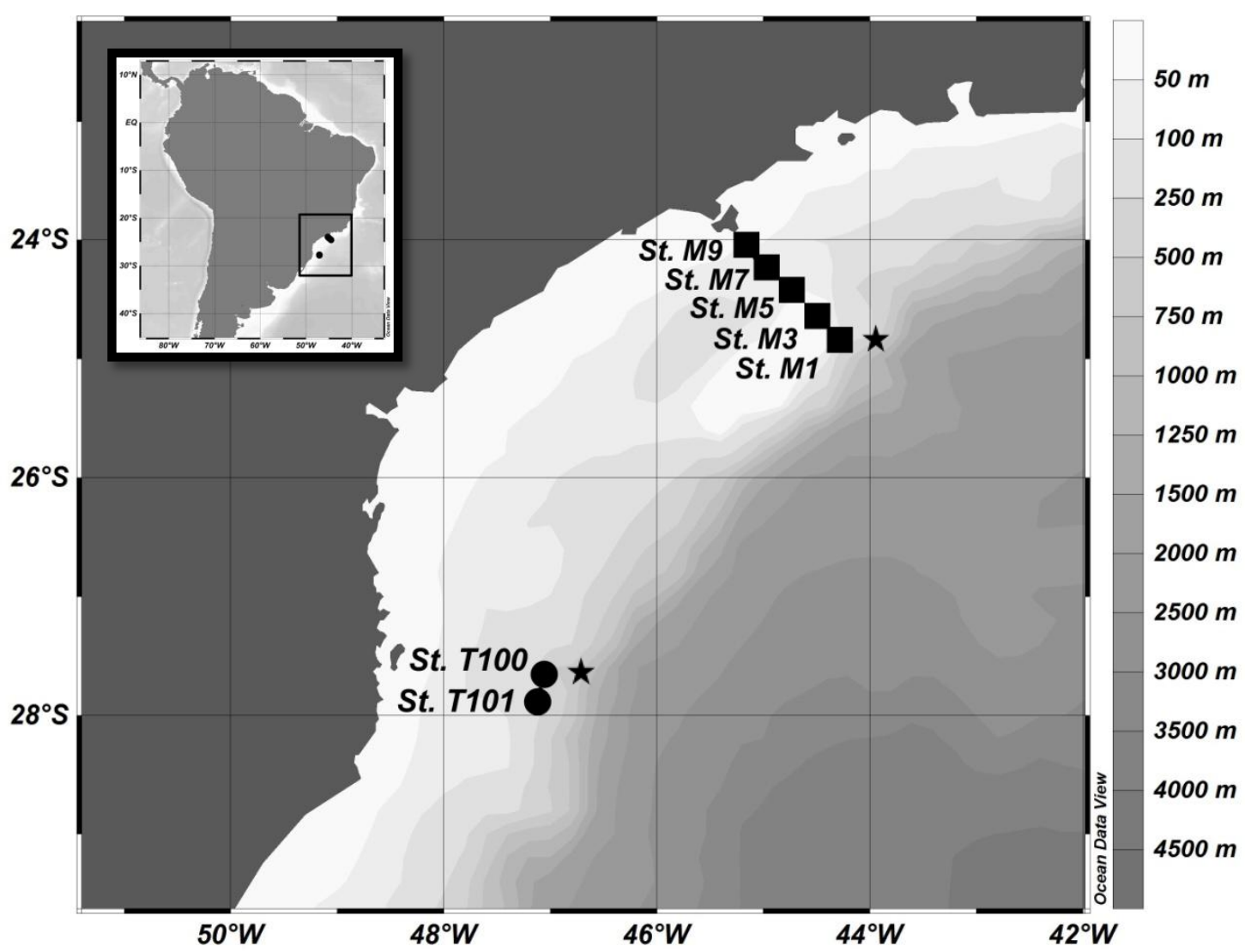

Figure 2.2. Location of sampling stations in the SAO off Brazil, corresponding to two cruises: Trichodesmium spp. bloom (St. T100 and St. T101) in November/2013 (dots) and Mesodinium rubrum bloom (St. M1, St. M3, St. M5, St. M7 and St. M9) in July/2014 (squares). Sampling stations right above the blooms are marked with a star (samples TRICHO and MR1/MR3). 


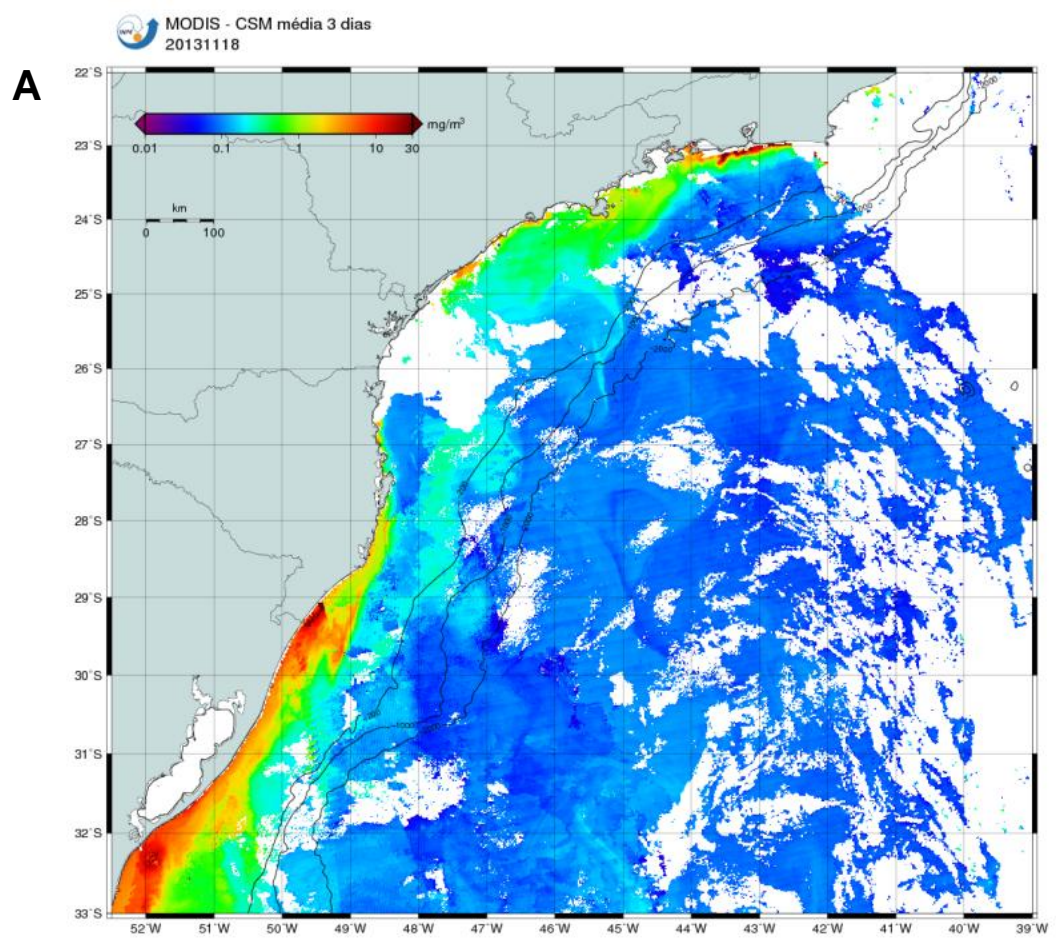

B

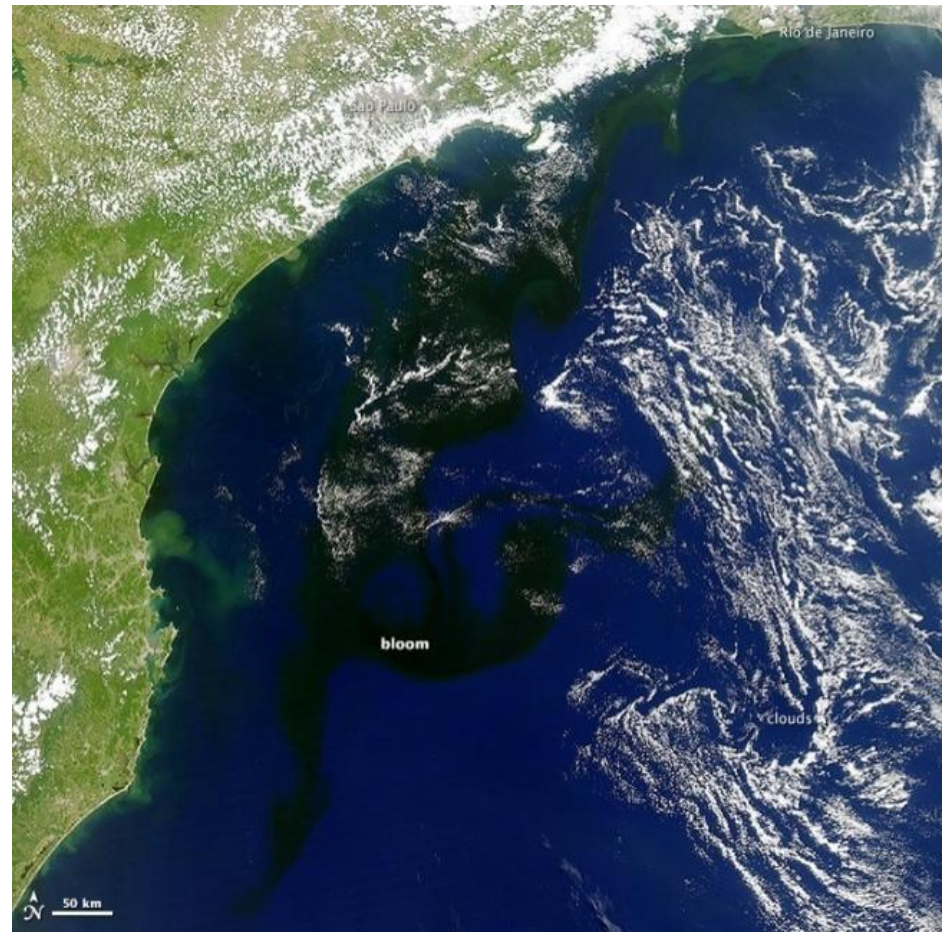

Figure 2.3. A) Satellite imagery (MODIS - Moderate Resolution Imaging Spectroradiometer) showing mean surface chlorophyll concentration $\left(\mathrm{mg} \cdot \mathrm{m}^{3}\right)$ in the Trichodesmium spp. bloom area, during its occurrence (3-days compilation). B) Satellite imagery (MODIS) showing the extension of the M. rubrum in the Brazilian coast. 


\subsubsection{Epifluorescence microscopy}

Samples for epifluorescence microscopy were kept in 50mL falcon tubes prepared with $2 \mathrm{~mL}$ of formaldehyde for fixation, and frozen until processing. DAPI (4',6-diamidino-2-phenylindole) (Sigma-Aldrich, St. Louis, Missouri, EUA) was used as dye for visualization, in a concentration of $15 \mu \mathrm{L}$ for each $1 \mathrm{~mL}$ of sample. After the mixing of the dye, the sample was left for 5 minutes in the dark, filtered in $0.22 \mu \mathrm{m}$ GF/F Whatman ${ }^{\circledR}$ and visualized in a Olympus BX-52 ${ }^{\circledR}$ epifluorescence microscope. 


\subsection{RESULTS}

\subsubsection{Trichodesmium spp. bloom}

The percentage of relative contribution between HNA and LNA bacteria was equilibrated throughout the stations, as can be observed in Figure 2.4 (A). In TRICHO station HNA reached 53\%, the highest values in comparison with the adjacent sampling points. The maxima for LNA bacteria was obtained in $101 \mathrm{~T}-\mathrm{e}(68 \%)$. The mean relative contribution of adjacent samples of the Trichodesmium spp. bloom were $39 \%$ for HNA and $61 \%$ for LNA. Bacterial abundance (HNA and LNA) in TRICHO was $3 \times 10^{6}$ cells. $\mathrm{mL}^{-1}$, being $2 \times 10^{6}$ cells. $\mathrm{mL}^{-1}$ of HNA bacteria and $1 \times 10^{6}$ cells. $\mathrm{mL}^{-1}$ of LNA bacteria. For the adjacent sampling sations (T100 and T101), the maxima were lower, $5 \times 10^{5}$ cells. $\mathrm{mL}^{-1}$ for HNA and $6 \times 10^{5}$ cells. $\mathrm{mL}^{-1}$ for LNA (Figure $2.4-$ B), and the mean abundance was $2 \times 10^{5}$ cells. $\mathrm{mL}^{-1}$ for HNA and $4 \times 10^{5}$ cells. $\mathrm{mL}^{-1}$ for LNA bacteria.

In the Trichodesmium spp. bloom the abundance of Prochlorococcus was the lowest among all samples in the vicinity (62 cells. $\left.\mathrm{mL}^{-1}\right)$, but Synechococcus abundance peaked $\left(335 \times 10^{3}\right.$ cells. $\left.\mathrm{ml}^{-1}\right)$ (Figure 2.5 - A). The mean abundances of nearby samples were $84 \times 10^{3}$ cells.ml $^{-1}$ for Prochlorococcus and $4 \times 10^{3}$ cells. $\mathrm{ml}^{-1}$ for Synechococcus. The maxima observed outside the bloom were $291 \times 10^{3}$ cells. $\mathrm{ml}^{-1}$ for Prochlorococcus and $11 \times 10^{3}$ cells. $\mathrm{ml}^{-1}$ for Synechococcus. Regarding the relative importance of each picocyanobacterial group, apart from the bloom station (TRICHO) and the 
surface samples $101 \mathrm{~T}-\mathrm{a}$, samples were dominated (>90\%) by Prochlorococcus (Figure 2.5 - B).

In the Trichodesmium spp. bloom both pico- and nanoeukaryotic abundances were not significantly impacted, since their cell numbers seem to follow closely the patterns from the samples in the vicinity (Figure 2.6 - A). Pico- and nanoeukaryote abundances inside the bloom (TRICHO) were 767 and $1 \times 10^{3}$ cells. $\mathrm{ml}^{-1}$, respectively. The abundance in the other samples varied between 86 and $3 \times 10^{3}$ cells. $\mathrm{ml}^{-1}$, for picoeukaryotes (mean of 666 cells. $\mathrm{ml}^{-1}$ ) and from 81 to $2 \times 10^{3}$ cells.ml ${ }^{-1}$, for nanoeukaryotes (mean of 669 cells.ml ${ }^{-1}$ ). The relative contribution between pico- and nanoeukaryotes was highly variable among samples, with an increase in nanoeukaryotes percentage in station TRICHO (Figure 2.6 - B). Phycoerythrin-containing eukaryotes were absent in this both inside or nearby Trichodesmium spp. bloom.

The heterotrophic biomass (HNA and LNA bacteria) had a visible increase inside Trichodesmium spp. bloom, when compared to the surrounding samples (Figure 2.8 - A). In TRICHO station HNA and LNA biomass were 32 $\mu \mathrm{gC} . \mathrm{L}^{-1}$ and $28 \mu \mathrm{gC} . \mathrm{L}^{-1}$, respectively. On nearby samples biomass varied between $2 \mu \mathrm{gC}, \mathrm{L}^{-1}$ and $10 \mu \mathrm{gC} . \mathrm{L}^{-1}$ (HNA) and $3 \mu \mathrm{gC} . \mathrm{L}^{-1}$ and $11 \mu \mathrm{gC} . \mathrm{L}^{-1}$ (LNA). Despite the increase in biomass, the relative contribution of heterotrophic biomass to total biomass decreased, as can be observed in Figure 2.8 (B), mostly due to a significant raise in Synechococcus biomass (86 $\mu \mathrm{gC} . \mathrm{L}^{-1}$, almost $60 \%$ of total biomass). As an opposite pattern it was observed a decrease in both Prochlorococcus (nearly absent) and picoeukaryotes $\left(2 \mu \mathrm{gC} . \mathrm{L}^{-1}\right)$ inside the Trichodesmium bloom, which was reflected on their relative contribution (Figure 2.8 - B). 
Epifluorescence microscopy showed the presence of regions with different patterns of pigmentations, even inside the same colony (Figure 2.9 A). Colonies were present as "tuft" (fusiform morphology) or as single trichomes (Figure 2.9 - B). It could be observed colonies with different terminations (Figure $2.9-$ C) and the presence of diazocytes, clearer cells specialized in the nitrogen fixation process (Figure 2.9 - D). In some trichomes it was observed the agglutination of genetic material in the extremities (Figure 2.9 - E, F). Mostly filamentous bacteria were observes as epibionts (Figure - 2.9 G, H).

Two sequences were recovered from the superficial samples of the Trichodesmium spp. bloom (1 from picoeukaryotes and 1 from nanoeukaryotes), both of them related to Braarudosphaeraceae, as can be observed in Figure 1.15 from Chapter 1. No sequence was recovered from the M. Rubrum bloom.

\subsubsection{Mesodinium rubrum bloom}

Immediately above the M. rubrum bloom, HNA contributed for $46 \%$ of total heterotrophic bacterial abundance (Figure 2.4 - A). The maximum and minimum obtained were the same for both HNA and LNA bacteria, being $60 \%$ and $40 \%$, respectively. The mean percentages relative to samples near the $M$. rubrum bloom were $48 \%$ for HNA and $52 \%$ for LNA. Abundance of HNA and LNA bacteria was higher in the M. rubrum cruise, with maximum of $2 \times 10^{6}$ cells. $\mathrm{ml}^{-1}$ for HNA and $3 \times 10^{6}$ cells. ml ${ }^{-1}$ for LNA, being both obtained in the same surface sample (MR3), from inside the bloom (Figure 2.4 - A, sample MR3). In 
the samples near the bloom (from MR4 to MR15), the mean abundance was $1 \times 10^{6}$ cells. $\mathrm{ml}^{-1}$ for both HNA and LNA bacteria.

In the surface samples directly above the M. rubrum bloom (MR1 and MR3) there was a peak in Prochlorococcus abundance, with $158 \times 10^{3}$ cells. $\mathrm{ml}^{-1}$ and $267 \times 10^{3}$ cells. $\mathrm{ml}^{-1}$, respectively (Figure 2.5 - A). The Prochlorococcus maximum observed in the nearby samples was lower $68 \times 10^{3}$ cells. $\mathrm{ml}^{-1}$, with a mean of $29 \times 10^{3}$ cells. $\mathrm{ml}^{-1}$.

High abundances of Synechococcus were observed in both MR1 and MR3 as well, with $246 \times 10^{3}$ cells. $\mathrm{ml}^{-1}$ and $268 \times 10^{3}$ cells. $\mathrm{ml}^{-1}$, respectively, and also in MR10 and MR11 (Figure 2.5 - A). The mean Synechococcus abundance of nearby samples was $61 \times 10^{3}$ cells. $\mathrm{ml}^{-1}$. With the exception of few samples, samples from the $M$. rubrum bloom cruise were dominated ( $>50 \%$ ) by Synechococcus (Figure 2.5 - B).

Picoeukaryotic abundance in MR1 and MR3 were $4 \times 10^{3}$ cells. $\mathrm{ml}^{-1}$ and $6 \times 10^{3}$ cells. $\mathrm{ml}^{-1}$, respectively, but it peaked outside the $M$. rubrum bloom $\left(29 \times 10^{3}\right.$ cells. $\mathrm{ml}^{-1}$, at MR6) (Figure 2.6 - A). Nanoplankton abundance was more homogenous, reaching $2 \times 10^{3}$ cells. $\mathrm{ml}^{-1}$ in both MR1 and MR3, and with a mean abundance also of $2 \times 10^{3}$ cells. $\mathrm{ml}^{-1}$ in the vicinity of the bloom. It was detected the presence of phycoerythrin-containing eukaryotes (Figure 2.6 - A and $2.7 \mathrm{~A}, \mathrm{~B})$, both inside the bloom $\left(2 \times 10^{3}\right.$ cells. $\left.\mathrm{ml}^{-1}, \mathrm{MR} 3\right)$ as well as in other samples $\left(1 \times 10^{3}\right.$ cells.ml ${ }^{-1}$, MR15). Apart from a few samples, picoeukaryotes were dominant (>50\%) nearby the bloom, reaching $90 \%$ at some sampling points (Figure $2.6-$ B).

HNA and LNA biomass were high throughout the top layers of the $M$. rubrum cruise, except for MR7 (Figure 2.8 - A). Samples inside the bloom 
reached $46 \mu \mathrm{gC}, \mathrm{L}^{-1}$ (HNA) and $56 \mu \mathrm{gC} . \mathrm{L}^{-1}$ (LNA) in MR3, but increased values were found also on nearby samples $\left(43 \mu \mathrm{gC} . \mathrm{L}^{-1}\right.$ for HNA in MR10 and $50 \mu \mathrm{gC} . \mathrm{L}^{-}$ 1 for LNA in MR13). Prochlorococcus biomass was low throughout the transect (maximum of $10 \mu \mathrm{gC} . \mathrm{L}^{-1}$, inside the bloom), with a incipient contribution to total biomass (Figure 2.8 - B). It was observed an increase in Synechococcus biomass and relative contribution in the profile of the $M$. rubrum bloom (69 $\mu g C . L^{-1}$ in MR3). High picoeukaryotic biomass was found especially in the vicinity of the bloom (maximum of $75 \mu \mathrm{gC} . \mathrm{L}^{-1}, \mathrm{MR} 6$ ) (Figure $2.8-\mathbf{A}$ ).

The light microcopy image (Figure - 2.10) shows a possible situation of kleptoplasty between $M$. rubrum and a cryptophyte. An intense phycoerythrin fluorescence from Mesodinium rubrum was captured by epifluorescence microscopy performed without the addition of dye (Figure - 2.11). 


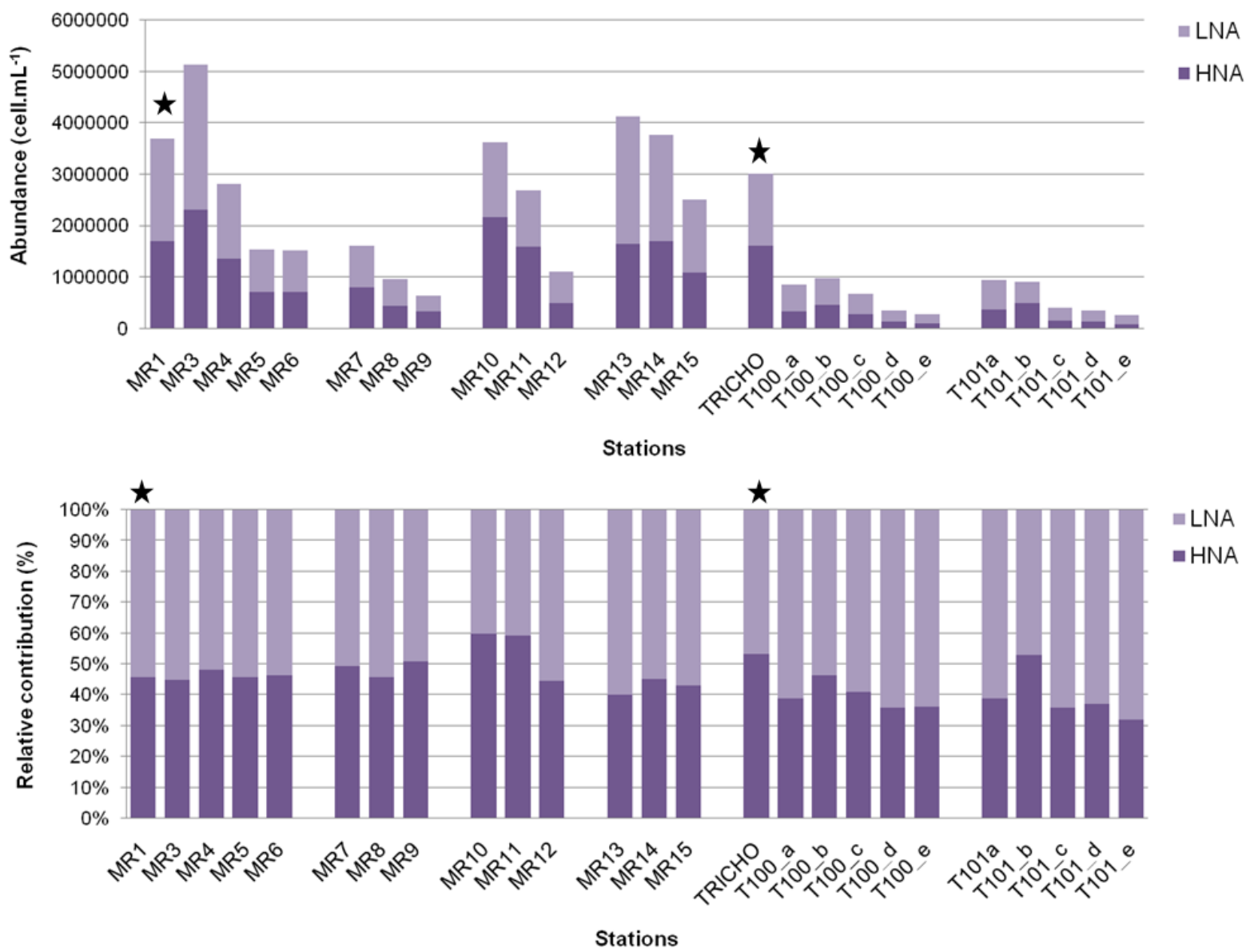

Figure 2.4. A) Abundance (in cells. $\mathrm{mL}^{-1}$ ) and B) relative contribution (in percentage) of HNA (dark purple) and LNA (light purple), for both M. rubrum (MR1 to MR15) and Trichodesmium spp. bloom (TRICHO and adjacent sampling stations, T100 and T101). Shaded stars represent samples immediately above the blooms. 


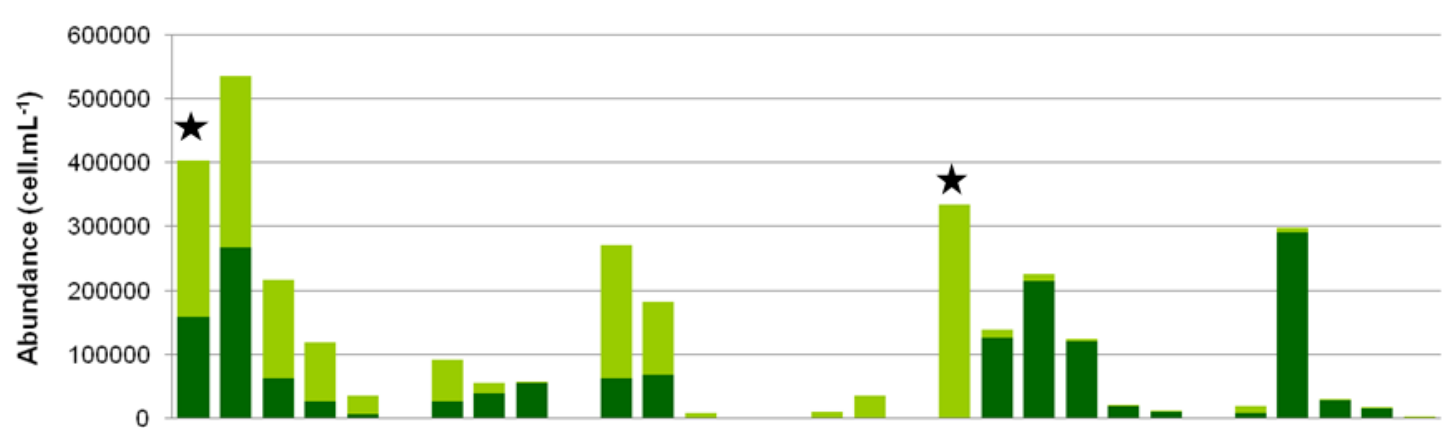

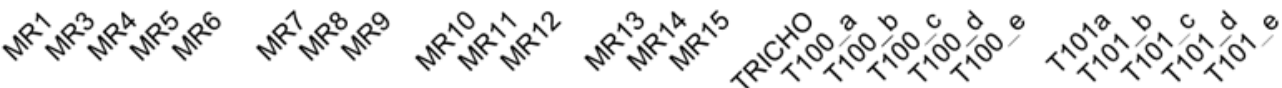

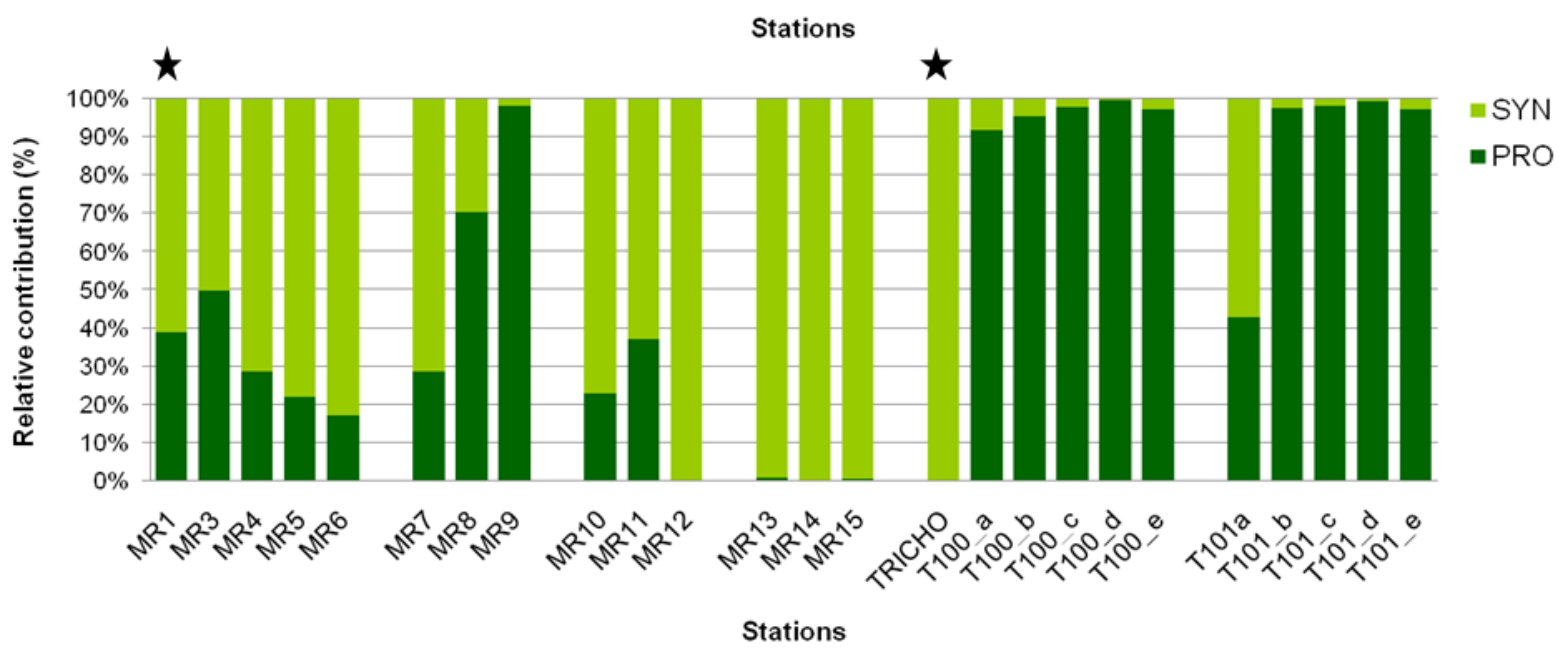

Figure 2.5. A) Abundance (in cells. $\mathrm{mL}^{-1}$ ) and B) relative contribution (in percentage) of Prochlorococcus (dark green) and Synechococcus (lime green), for both M. rubrum (MR1 to MR15) and Trichodesmium spp. bloom (TRICHO and adjacent sampling stations, T100 and T101). Shaded stars represent samples immediately above the blooms. 

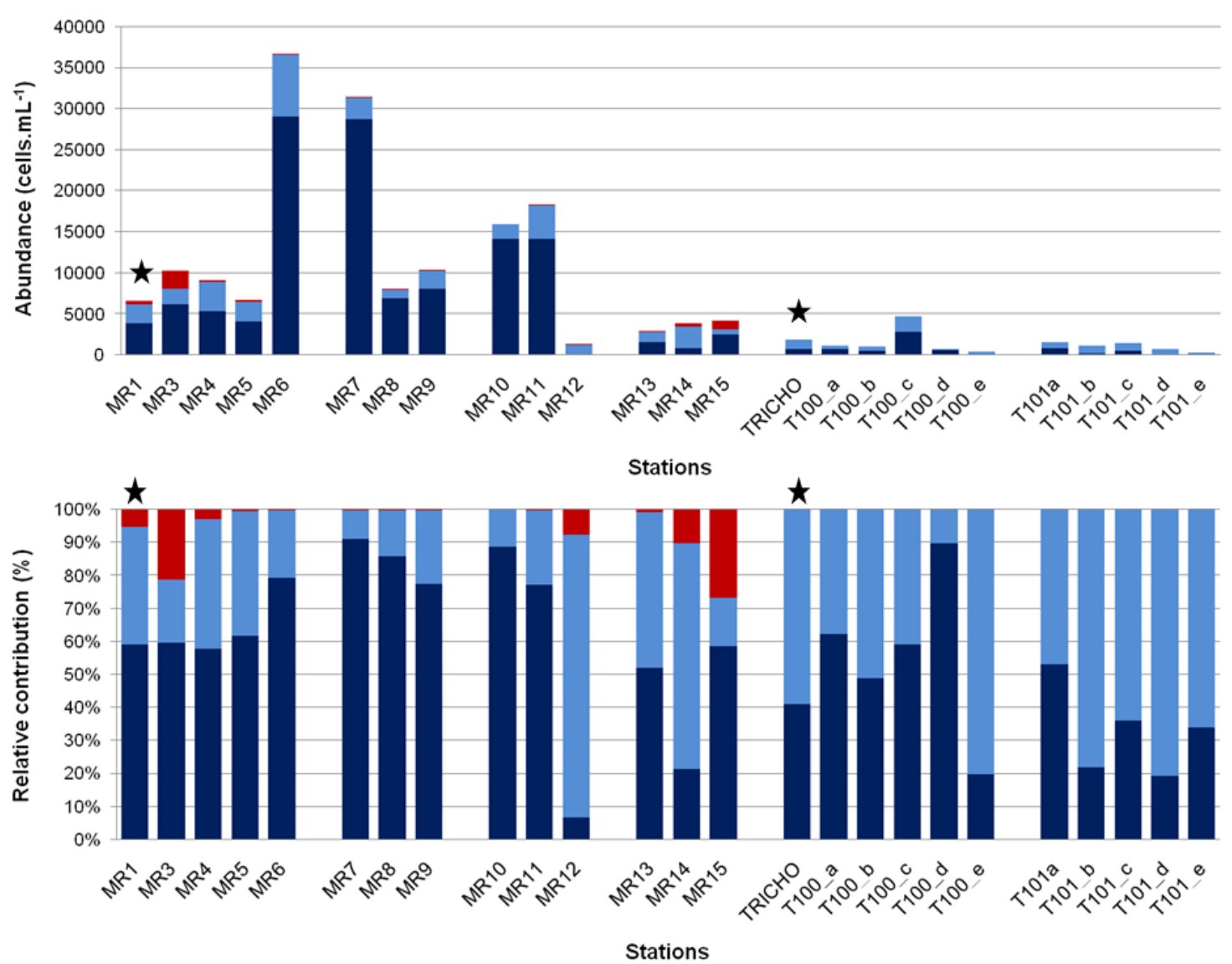

Figure 2.6. A) Abundance (in cells. $\mathrm{mL}^{-1}$ ) and B) relative contribution (in percentage) of picoeukaryotes (dark blue), nanoeukaryotes (light blue) and phycoerythrin-containing eukaryotes (red), for both M. rubrum (MR1 to MR15) and Trichodesmium spp. bloom (TRICHO and adjacent sampling stations, T100 and T101). Shaded stars represent samples immediately above the blooms. 

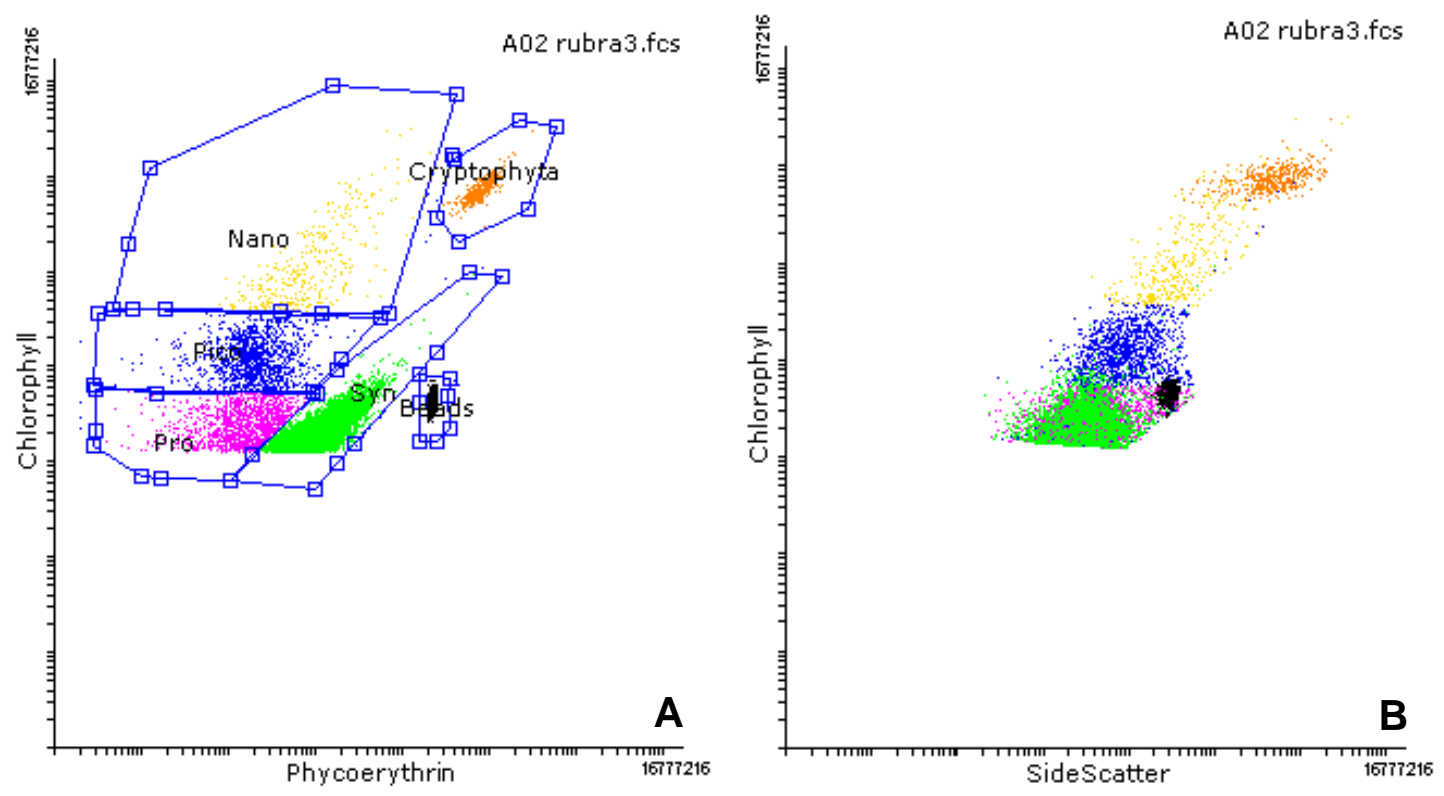

Figure 2.7. Cytograms of A) Phycoerythrin versus Chlorophyll and B) SSC (side scatter) versus Chlorophyll data of sample MR3, showing the following gating patterns: Prochlorococcus (pink), Synechococcus (green), picoeukaryotes (blue), nanoeukaryotes (yellow) and phycoerythrin-containing eukaryotes (presumably Cryptophyta) (orange). Calibrations beads are marked in black. 


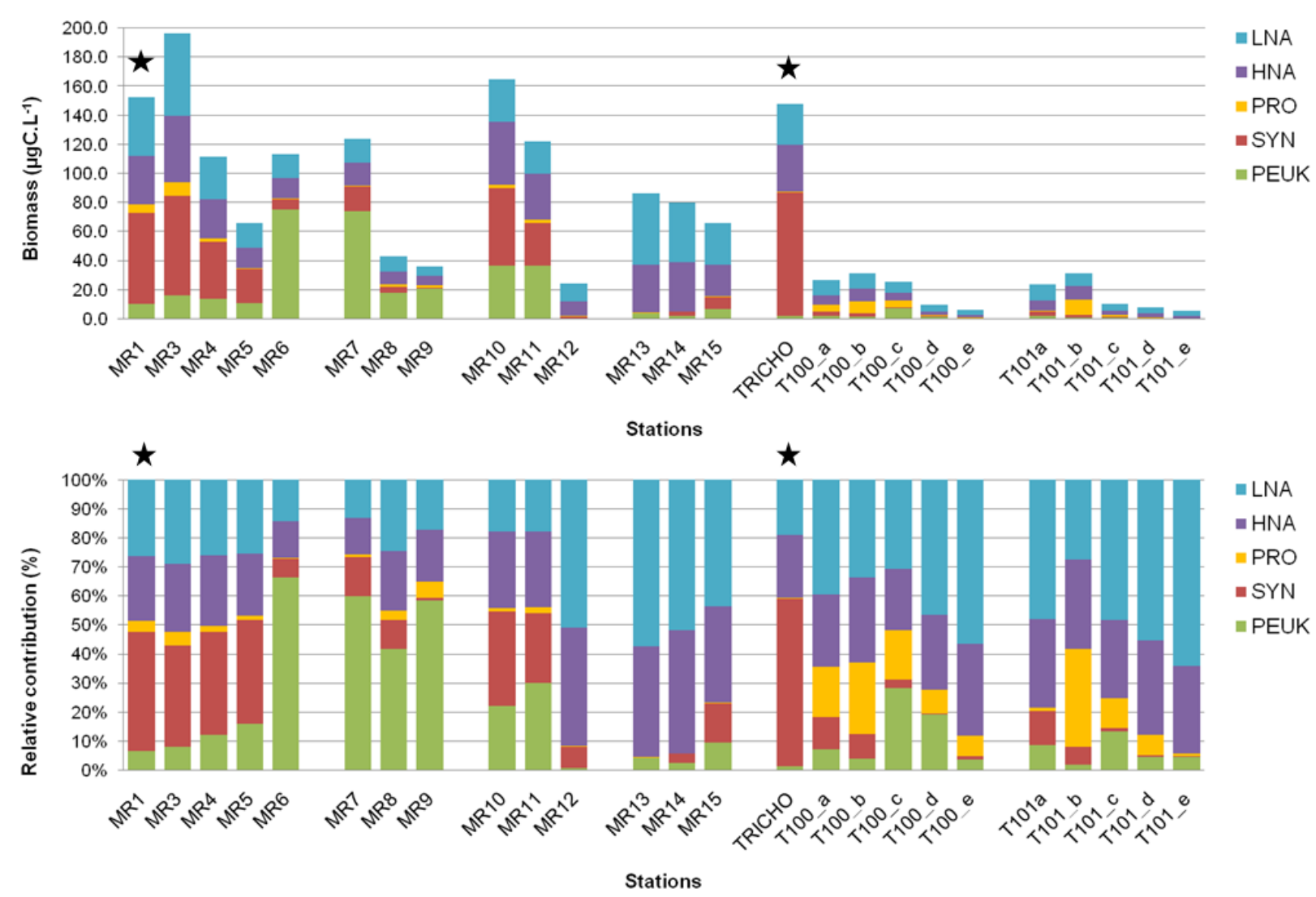

Figure 2.8. A) Biomass (in $\mu \mathrm{gC} . \mathrm{L}^{-1}$ ) and $\mathbf{B}$ ) its relative contribution (in percentage) of picoeukaryotes (green), Synechococcus (red), Prochlorococcus (yellow), HNA (purple) and LNA (blue) bacteria, for both M. rubrum (MR1 to MR15) and Trichodesmium spp. bloom (TRICHO and adjacent sampling stations, T100 and T101). Shaded stars represent samples immediately above the blooms. 

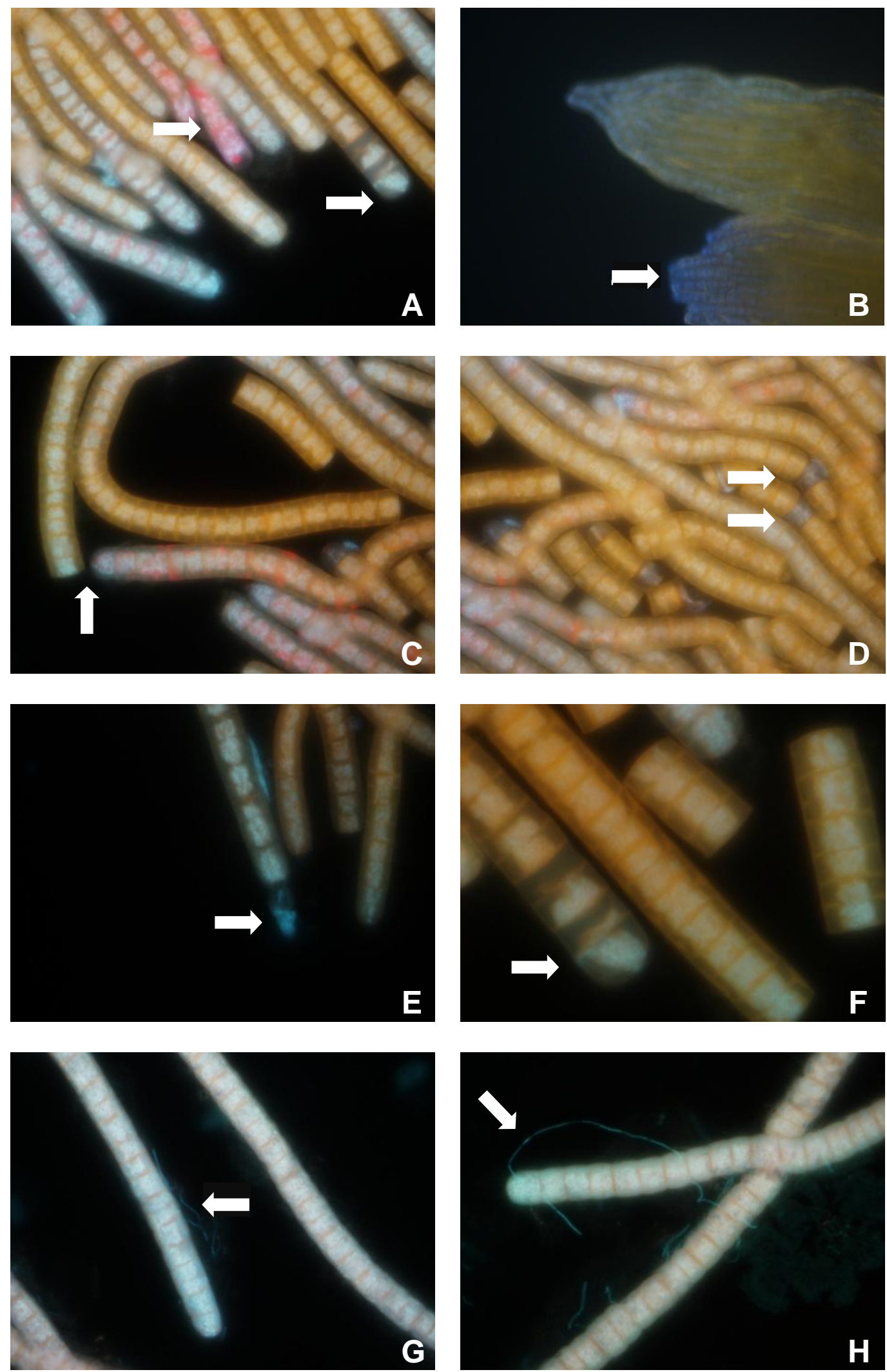

Figure 2.9. Epifluorescence microscopy images from the Trichodesmium spp. bloom, showing the following features: A) different pigmentation; B) tuft morphology; C) different terminations; D) diazocytes; E, F) accumulation of genetic material and $\mathbf{G}, \mathbf{H}$ ) epibiont community. 


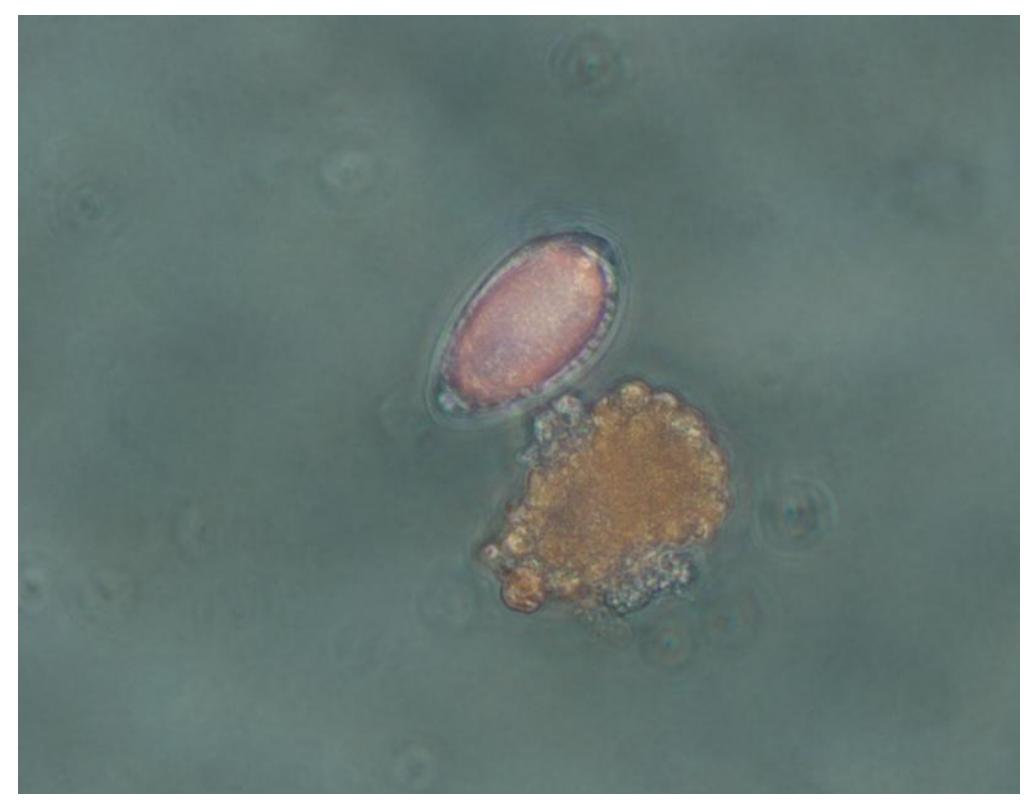

Figure 2.10. Possible kleptoplasty occurrence between Mesodinium rubrum and cryptophyte captured on light microscopy image from the M. rubrum cruise. Samples were courtesy of Salvador Airton Gaeta and Mayza Pompeu (LaPP/IOUSP).

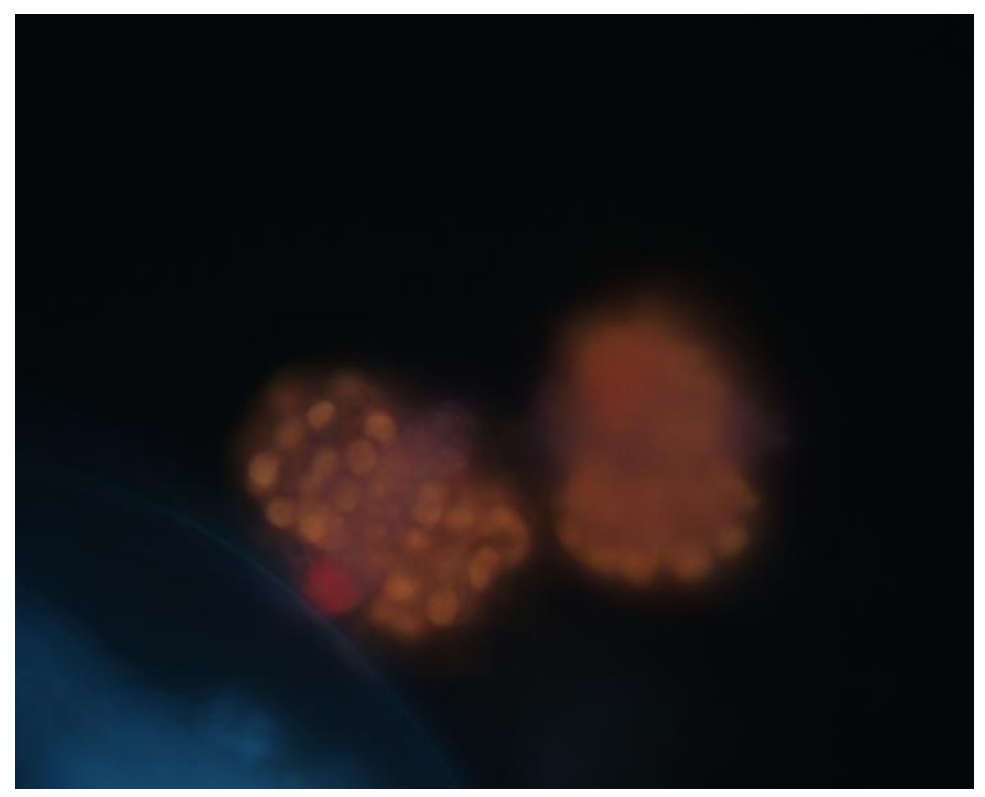

Figure 2.11. Phycoerythrin fluorescence from Mesodinium rubrum captured on epifluorescence microscopy image from the $M$. rubrum cruise. Samples were courtesy of Salvador Airton Gaeta and Mayza Pompeu (LaPP/IOUSP). 


\subsection{DISCUSSION}

The sampling stations right above the blooms (TRICHO and MR1/MR3) were both located in the outer-shelf (Figure 2.2). However, both latitudinal and seasonal differences between the cruises prevent a direct comparison over the observed influence of each bloom in the overall picoplanktonic community. That said, we were able to investigate if the conditions encountered inside each bloom were also noticed in the nearby samples, both vertically (in the water column) and horizontally.

Epifluorescence microscopy allows the visualization of cellular structures as well as communities associated with Trichodesmium colonies, as the DAPI dye bonds with adenine and thymine regions from the genetic material. The central regions, well delimitated and clearer, correspond to the nucleoplasmic region of the cells, which holds the genetic material. The gas vacuoles are present in the shaded laterals of the trichomes, and occupy from $60 \%$ to $70 \%$ of the cellular volume, acting both as floating device and protection from the deleterious effects of high light incidence in the surface of the oceans (VAN BAALEN \& MALCOLM BROWN, 1969). The red-colored regions potentially host photosynthetic pigments, like chlorophyll. Accordingly to Van Baalen \& Malcolm Brown, (1969), photosynthetic lamellae are mainly located in the central portions of the cells although they can enter the region of gas vacuoles and extend to the cell surface (VAN BAALEN \& MALCOLM BROWN, 1969). Long and thin filamentous epibionts are characteristic of Trichodesmium spp. blooms, especially in the 'tuft' morphology (PAERL; BEBOUT; PRUFERT, 1989; 
SHERIDAN; STEINBERG; KLING, 2002). The epibionts feed on the mucilage of the colonies and low molecular weight photosynthetic exudates (CARPENTER; CAPONE, 1992).

The Trichodesmium spp. bloom had a high impact in HNA/LNA bacterial abundance (Figure 2.4 - A), which was at least 3 times higher than any other sample in the vicinity. In different studies in the southwest Atlantic and Pacific Oceans, the authors have not found any significant enrichment in heterotrophic bacteria inside a Trichodesmium spp. bloom (CAMPBELL et al., 2005; SIQUEIRA; KOLM; BRANDINI, 2006). The increase in HNA/LNA bacteria observed in this study might be linked to a senescent phase of the bloom (SIQUEIRA; KOLM; BRANDINI, 2006), causing accelarated cells disruption and abundant organic material release to the water column (CARPENTER; CAPONE, 1992).

Inside the Trichodesmium spp. bloom observed in this study (St. TRICHO) there was an approximately 30 -fold increase in Synechococcus abundance (Figure 2.5 - A), which highly differed from the nearby stations, dominated by Prochlorococcus (Figure 2.5 - B). This is a similar pattern to what Campbell et al., (2005) have found (a 10-fold increase in Synechococcus abundances) inside a Trichodesmium spp. bloom in the Southwest Pacific.

The presence of a superficial bloom did not seemed to influence populations in deeper layers of the water column, even though Trichodesmium spp. cells may export up to $90 \%$ of its recently fixed nitrogen during growth (MULHOLLAND; BERNHARDT, 2005).

The bloom had no effect on the pico- and nanoeukaryotic abundance, a pattern that was observed before by Campbell et al., (2005). In the present 
study, the dominant presence of Haptophyta sequences in surface samples related to the host of a diazotrophic unicellular cyanobacteria (see Chapter 1), even inside the Trichodesmium bloom (Figure 1.15 - Chapter 1), might suggest that the pico- and nanoeukaryotic populations in the region are possibly less dependent of the nutritional state of the surrounding water, and so less prone to variability in a bloom situation.

As expected by the high Synechococcus abundance observed inside the Trichodesmium spp. bloom, the autotrophic biomass in this station (TRICHO) was dominated (> 50\%) by this group (Figure $2.8-\mathbf{B}$ ). The elevated release of labile nitrogen compounds by Trichodesmium spp. nitrogen fixation (MULHOLLAND; BERNHARDT, 2005) may provide a suitable niche for Synechococcus growth, which are associated to mesotrophic waters (ZUBKOV et al., 1998).

Regarding M. rubrum, the HNA/LNA abundance inside the bloom was not significantly distinct from other surface samples in the same cruise. Since there is no preliminary data for the same season in the region, it is not possible to infer if the massive $M$. rubrum bloom was responsible for the increase in HNA/LNA abundance all over the area, or if the high heterotrophic abundance observed is a common feature in this region. The former situation is more likely, since by satellite imagery it is possible to visualize the bloom extension, up to coastal waters (Figure 2.3 - B). The increase in heterotrophic bacterial abundance can be a consequence to $M$. rubrum high photosynthetic capacity and production coupled with elevated biomass levels during the bloom (CRAWFORD, 1989). Previous studies indicate that $M$. rubrum blooms can significantly enhance microbial secondary production (HERFORT et al., 2012) 
due to elevated production of dissolved organic carbon (CRAWFORD et al., 1997). The fact that high HNA/LNA abundances were also observed in deeper layers (down to 30 meters) may reflect the depth range on which $M$. rubrum can be found due to its remarkable natatory capabilities, which can be of tens of meters per day (CRAWFORD, 1989; JOHNSON; STOECKER; MARSHALL, 2013). M. rubrum are able also to predate on heterotrophic bacteria (MYUNG et al., 2006), so the elevated bacterial abundance might as well serve as a nutritional alternative.

The differences between bacterial abundance were not reflected in the relative contribution of each group, since the proportion between HNA and LNA bacteria remained relatively balanced in both cruises, with a slightly increase in HNA relative contribution in the Trichodesmium spp. bloom (Figure 2.4 - B).

In the samples right above the $M$. rubrum bloom there was an increase in picocyanobacterial abundance (MR1 and MR3), and a high Synechococcus dominance was observed in most stations of the transect. The high Synechococcus abundance observed on MR cruise may be explored as an alternative feeding source for $M$. rubrum cells, since the ciliate was reported to be an effective grazer of Synechococcus populations (YOO et al., 2015).

The significant raise in picoeukaryotic abundance observed in some samples of the M. rubrum cruise didn't seem to follow a distinguishable pattern (Figure $2.6 \quad$ - A). Phycoerythrin-containing eukaryotes (presumably Cryptophyta) were detected in variable concentrations in the cruise, with an abundance peak inside the bloom (sample MR3, Figure 2.6 - A). Previous studies reported a positive correlation between $M$. rubrum blooms formation and cryptophyte abundance (JOHNSON; STOECKER; MARSHALL, 2013). M. 
rubrum is known to contain symbionts of cryptophyte origin from the Teleaulax / Plagioselmis / Geminigera (TPG) clade (GUSTAFSON et al., 2000; HANSEN et al., 2012), with high levels of phycoerythrin (DIERSSEN et al., 2015). M. rubrum can retain transcriptionally active cryptophyte nuclei for up to 30 days (JOHNSON et al., 2007). Although requiring the ingestion of one cryptophyte cell per day to maintain the maximum growth rate (SMITH; HANSEN, 2007), $M$. rubrum can grow for approximately six weeks in the absence of a plastid donator (MYUNG et al., 2013). Therefore, even surface samples with low cryptophyte abundance in the vicinity of the bloom (like M7 and M10, Figure 2.6 - A) can be suitable to sustain M. rubrum survival and growth.

The picoplankton biomass distribution inside $M$. rubrum bloom with high surface carbon biomass from heterotrophic bacteria and Synechococcus (Figure 2.8 - A) suggests these populations might have fueled the ciliate proliferation (MYUNG et al., 2006; YOO et al., 2015). There is probably a nutritional positive feedback, since $M$. rubrum blooms tend to have a high level of organic nutrients release to the environment, possibly enhancing heterotrophic bacteria and Synechococcus biomass (HERFORT et al., 2012). 


\subsection{CONCLUSIONS}

Some picoplanktonic groups seem to be more prone to modification by the blooms development. Heterotrophic bacteria and Synechococcus were greatly enhanced in both Trichodesmium spp. and Mesodinium rubrum blooms. High densities of Trichodesmium cells exert less influence on the surrounding waters than $M$. rubrum, probably due to the known elevated rates of organic carbon release and remarkable motility of the latter.

Information about the influence of blooms on the picoplankton community is extremely scarce for Trichodesmium spp. and nonexistent until now for $M$. rubrum. More quantitative and qualitative studies focusing this issue are needed in order to improve our knowledge on the triggering, development and decay of these blooms. 


\subsection{REFERENCES}

BAALEN, C. VAN; MALCOLM BROWN. BAALEN_1969 estrutura tricomas.pdf. Archives of microbiology, v. 69, p. 79-91, 1969.

BERMAN-FRANK, I. et al. Coupling between autocatalytic cell death and transparent exopolymeric particle production in the marine cyanobacterium Trichodesmium. Environmental Microbiology, v. 9, n. 6, p. 1415-1422, 2007.

CAMPBELL, L. et al. Picoplankton community structure within and outside a. Water, v. 55, p. 185-195, 2005.

CAPONE, D. G. Trichodesmium, a Globally Significant Marine Cyanobacterium. Science, v. 276, n. MAY, p. 1221-1229, 1997.

CARPENTER, E. J.; CAPONE, D. G. Marine Pelagic Cyanobacteria: Trichodesmium and other Diazotrophs. Dordrecht, Netherlands: Kluwer Academic Publ, 1992.

CARVALHO, M.; GIANESELLA, S. M. F.; SALDANHA-CORRÊA, F. M. P. Trichodesmium Erythraeum bloom on the continental shelf off Santos, Southeast Brazil. Brazilian Journal of Oceanography, v. 56, n. March 2006, p. 307-311, 2008.

COLES, V. J. et al. Modeling the impact of Trichodesmium and nitrogen fixation in the Atlantic ocean. Journal of Geophysical Research C: Oceans, v. 109, p. 1-17, 2004.

CRAWFORD, D. Mesodinium rubrum: the phytoplankter that wasn't . Marine Ecology Progress Series, v. 58, n. 1988, p. 161-174, 1989.

CRAWFORD, D. W. et al. Recurrent Red-tides in the Southampton Water Estuary Caused by the Phototrophic CiliateMesodinium rubrum. Estuarine, Coastal and Shelf Science, v. 45, p. 799-812, 1997. 
DAVIS, C. S.; MCGILLICUDDY, D. J. Transatlantic abundance of the N2-fixing colonial cyanobacterium Trichodesmium. Science (New York, N.Y.), v. 312, n. 2006, p. 1517-1520, 2006.

DETONI, A. M. S. et al. Toxic Trichodesmium bloom occurrence in the southwestern South Atlantic Ocean. Toxicon, v. 110, p. 51-55, 2016.

DIERSSEN, H. et al. Space station image captures a red tide ciliate bloom at high spectral and spatial resolution. Proceedings of the National Academy of Sciences, 2015.

FERNÁNDEZ, A. et al. Latitudinal distribution of Trichodesmium spp. and N2 fixation in the Atlantic Ocean. Biogeosciences, v. 7, n. 2009, p. 3167-3176, 2010.

GLIBERT, P. M.; BRONK, D. A. Release of Dissolved Organic Nitrogen by Release of Dissolved Organic Nitrogen by Marine Diazotrophic. Applied and Environmental Microbiology, v. 60, n. 11, p. 3996-4000, 1994.

GUSTAFSON, D. E. et al. Cryptophyte algae are robbed of their organelles by the marine ciliate Mesodinium rubrum. Nature, v. 405, n. June, p. 1049-1052, 2000.

HANSEN, P. J. et al. Direct evidence for symbiont sequestration in the marine red tide ciliate Mesodinium rubrum. Aquatic Microbial Ecology, v. 66, p. 6375, 2012.

HERFORT, L. et al. Red Waters of Myrionecta rubra are Biogeochemical Hotspots for the Columbia River Estuary with Impacts on Primary/Secondary Productions and Nutrient Cycles. Estuaries and Coasts, v. 35, p. 878-891, 2012.

HYNES, A. M. et al. Cross-basin comparison of phosphorus stress and nitrogen fixation in Trichodesmium. Limnology and Oceanography, v. 54, n. 5, p. 1438-1448, 2009. 
JOHNSON, M. D. et al. Retention of transcriptionally active cryptophyte nuclei by the ciliate Myrionecta rubra. Nature, v. 445, n. 7126, p. 426-8, 2007.

JOHNSON, M. D.; STOECKER, D. K.; MARSHALL, H. G. Seasonal dynamics of Mesodinium rubrum in Chesapeake Bay. Journal of Plankton Research, v. 35, p. 877-893, 2013.

JOLLIFF, J. K. et al. The impact of coastal phytoplankton blooms on oceanatmosphere thermal energy exchange: Evidence from a two-way coupled numerical modeling system. Geophysical Research Letters, v. 39, n. 24, p. n/a-n/a, 2012.

JUEL HANSEN, P.; FENCHEL, T. Harbours a Single Permanent Endosymbiont. Marine Biology Research, v. 2, n. September 2014, p. 169-177, 2006.

$K A R L$, D. et al. The role of nitrogen fixation in biogeochemical cycling in the subtropical North Pacific Ocean. Nature, v. 388, p. 533-538, 1997.

KYEWALYANGA, M.; SATHYENDRANATH, S.; PLATT, T. Effect of Mesodinium rubrum (= Myrionecta rubra) on the action and absorption spectra of phytoplankton in a coastal marine inlet. J. Plankton Res., v. 24, p. 687-702, 2002.

MAFRA JUNIOR, L. L.; FERNANDES, L. F.; PROENÇA, L. A. O. Harmful algae and toxis in paranaguá bay, Brazil: bases for monitoring. Brazilian Journal of Oceanography, v. 54, p. 107-121, 2006.

MOORE, C. M. et al. Processes and patterns of oceanic nutrient limitation. Nature Publishing Group, v. 6, n. March, p. 701-710, 2013.

MULHOLLAND, M. R.; BERNHARDT, P. W. The effect of growth rate, phosphorus concentration, and temperature on N2 fixation, carbon fixation, and nitrogen release in continuous cultures of Trichodesmium IMS101. Limnology and Oceanography, v. 50, n. 3, p. 839-849, 2005. 
MYUNG, G. et al. Ingestion of bacterial cells by the marine photosynthetic ciliate Myrionecta rubra. Aquatic Microbial Ecology, v. 44, n. 2, p. 175-180, 2006.

MYUNG, G. et al. Sequestered plastids in Mesodinium rubrum are functionally active up to 80 days of phototrophic growth without cryptomonad prey. Harmful Algae, v. 27, p. 82-87, 2013.

NAUSCH, M. Microbial activities on Trichodesmium colonies. Marine Ecology Progress Series, v. 141, p. 173-181, 1996.

PAERL, H. W.; BEBOUT, M. E.; PRUFERT, L. E. Bacterial associations with marine Oscillatoria sp. (Trichodesmium sp.) populations: ecophysiological implications. Journal of Phycology, v. 25, p. 773-784, 1989.

PAULO C. ABREU; BOPAIAH B. BIDDANDA; CLARISSE ODEBRECHT. Bacterial Dynamics of the Patos Lagoon Relationship with Phytoplankton Production and Suspended Material. Estuarine, Coastal and Shelf Science, v. 35, p. 621-635, 1992.

PÉREZ, M. T. et al. Diel vertical distribution of planktonic ciliates within the surface layer of the NW Mediterranean (May 1995). Deep-Sea Research Part I: Oceanographic Research Papers, v. 47, n. May 1995, p. 479-503, 1999.

PROENÇA, L. A red water caused by Mesodinium rubrum on the coast of Santa Catarina, southern Brazil. Brazilian Journal of Oceanography, v. 52, n. 2, p. 153-161, 2004.

SHERIDAN, C. C.; STEINBERG, D. K.; KLING, G. W. The microbial and metazoan community associated with colonies of Trichodesmium spp.: a quantitative survey. Journal of Plankton Research, v. 24, p. 913-922, 2002.

SIQUEIRA, A.; KOLM, H. E.; BRANDINI, F. P. Offshore distribution patterns of the cyanobacterium Trichodesmium erythraeum ehrenberg and associated phyto- and bacterioplankton in the southern atlantic coast (Paran??, Brazil). Brazilian Archives of Biology and Technology, v. 49, n. March, p. 323-337, 2006. 
SMITH, M.; HANSEN, P. J. Interaction between Mesodinium rubrum and its prey: Importance of prey concentration, irradiance and $\mathrm{pH}$. Marine Ecology Progress Series, v. 338, p. 61-70, 2007.

TYRRELL, T. et al. Large-scale latitudinal distribution of Trichodesmium spp. in the Atlantic Ocean. Journal of Plankton Research, v. 25, n. 4, p. 405-416, 2003.

WEStBERRY, T. K.; SIEGEL, D. A. Spatial and temporal distribution of Trichodesmium blooms in the world's oceans. Global Biogeochemical Cycles, v. 20 , p. $1-13,2006$.

YIH, W.; SHIM, J. The planktonic phototrophic ciliate, Mesodinium rubrum, as a useful organism for marine biotechnological applications. Journal of Marine Biotechnology, v. 5, p. 82-85, 1997.

YOO, Y. DU et al. Ingestion of the unicellular cyanobacterium Synechococcus by the mixotrophic red tide ciliate Mesodinium rubrum. Algae, v. 30, n. 4, p. 281-290, 2015.

ZUBKOV, M. V et al. Picoplanktonic community structure on an Atlantic transect from $50^{\circ} \mathrm{N}$ to $50^{\circ} \mathrm{S}$. Deep Sea Research Part I: Oceanographic Research Papers, v. 45, n. 8, p. 1339-1355, ago. 1998. 


\section{CHAPTER 3}

Estimating microbial populations by flow cytometry

Comparison between instruments 


\section{RESUMO}

Por quase duas décadas, a citometria de fluxo ( $\mathrm{FCM}$, sigla em inglês) permite aos pesquisadores investigar a comunidade planctônica dos oceanos utilizando sinais celulares de fluorescência, tamanho e rugosidade. No entanto, o uso amplo da FCM em estudos oceanográficos ainda enfrenta uma restrição metodológica: a resolução do equipamento utilizado em levantamentos científicos. Nós analisamos 102 amostras do sudoeste do Atlântico Sul, entre as latitudes $23^{\circ} 12^{\prime \prime} \mathrm{S}-30^{\circ} 53^{\prime \prime} \mathrm{S}$ e longitudes $39^{\circ} 23^{\prime \prime} \mathrm{W}-49^{\circ} 10^{\prime \prime} \mathrm{W}$, até a isóbata de 3510 metros, ao longo de três transectos, sendo 5 profundidades por perfil dentro da zona eufótica. O presente trabalho teve como objetivo investigar as limitações metodológicas impostas pelo uso de dois citômetros diferentes, BD FACSCanto $^{\mathrm{TM}}$ e BD Accuri ${ }^{\mathrm{TM}} \mathrm{C6}$ na contagem celular de bactérias heterotróficas, Prochlorococcus, Synechococcus, e pico- nanoeucariotos. O primeiro citômetro possui características ópticas de excitação e captura que lhe garantem alta acurácia e reprodutibilidade, enquanto o segundo apresenta vantagens críticas para o estudo de campo, como fácil manuseio e transporte, assim como um menor custo. Bactérias heterotróficas, pico e nanoeucariotos foram consistentemente distinguíveis com os dois citômetros, com uma boa correlação entre as medições. A detecção de Prochlorococcus e Synechococcus foi prejudicada pelo uso do citômetro de bancada BD Accuri ${ }^{\mathrm{TM}}$ C6, particularmente em amostras das camadas superiores da coluna d'água, bem iluminadas (acima dos 100 metros e 50 metros para Prochlorococcus e Synechococcus, respectivamente). A abordagem da correção da abundância baseada na distribuição gaussiana da fluorescência vermelha não foi suficiente para compensar completamente a baixa sensibilidade na maioria das leituras. O número crescente de estudos baseados em citometria de fluxo dentro da oceanografia biológica evidencia a importância da comparação entre dados de diferentes citômetros, com 0 intuito de evitar inferências ecológicas equivocadas na microbiologia marinha.

Palavras-chave: citometria de fluxo; bactérias heterotróficas, Prochlorococcus,

Synechococcus, picoeucariotos; nanoeucariotos, BD FACSCanto ${ }^{\mathrm{TM}}$, BD Accuri $^{\mathrm{TM}}$ C6. 


\section{ABSTRACT}

For almost two decades, flow cytometry (FCM) has allowed researchers to investigate the ocean's planktonic community using its cell's fluorescence signals, size and rugosity. Nevertheless, FCM widespread use in oceanographic studies still faces a methodological constraint: the resolution of the equipment used in scientific surveys. We have analyzed 102 samples from South Atlantic Ocean, from latitude $23^{\circ} 12^{\prime \prime S}-30^{\circ} 53^{\prime \prime} \mathrm{S}$ and longitude $39^{\circ} 23^{\prime \prime} \mathrm{W}-49^{\circ} 10^{\prime \prime} \mathrm{W}$, up to the 3510 meters isobath, along 3 transects, comprising 5 depths per profile within the euphotic zone. We aimed to investigate the methodological limitations imposed by the use of two different flow cytometers, BD FACSCanto ${ }^{\mathrm{TM}}$ and BD Accuri $^{\mathrm{TM}}$ C6, in the cell counting of heterotrophic bacteria, Prochlorococcus, Synechococcus, pico- and nanoeukaryotes. The former cytometer have optical characteristics of excitation and capture that grant it high accuracy and reproducibility, whilst the latter presents critical advantages for field studies, such as easy handling and transportation, and a relatively low cost. Heterotrophic bacteria, pico- and nanoeukaryotes were consistently distinguished with both cytometers, and the correlation between measurements was fairly fitting. Prochlorococcus and Synechococcus detection were impaired by the use of the benchtop cytometer BD Accuri ${ }^{\mathrm{TM}} \mathrm{C} 6$, particularly in samples from well-lit, top layers of the water column (above 100 meters and 50 meters depth for Prochlorococcus and Synechococcus, respectively). Abundance correction approaches based on red fluorescence Gaussian distribution were not sufficient to fully compensate the low sensibility in most of the readings. The increasing number of cytometry-based studies in biological oceanography highlights the importance of the comparison between outputs from different cytometers, in order to avoid biased ecological inferences in aquatic microbial ecology.

Keywords: flow cytometry, heterotrophic bacteria, Prochlorococcus, Synechococcus, picoeukaryotes; nanoeukaryotes, BD FACSCanto ${ }^{\mathrm{TM}}$, BD Accuri ${ }^{\mathrm{TM}} \mathrm{C6}$. 


\subsection{INTRODUCTION}

Planktonic populations can be differentiated by FCM accordingly to their specific rates of the recorded parameters (FSC, SSC, red or orange fluorescence) (Figure 3.1). Two heterotrophic bacterial groups can be distinguished by FCM, due its apparent nucleic acid content (differences in fluorescence intensity) and side scatter signal (SSC): high nucleic acid (HNA) and low nucleic acid (LNA) bacteria. The function and ecological importance of these two groups is far from being fully understood (BOUVIER; DEL GIORGIO; GASOL, 2007; VAN WAMBEKE et al., 2011). Even though some studies claim that HNA are the active, growing portion of the bacterioplankton (VIVES-REGO; LEBARON; CARON, 2000), others suggest that LNA cells can be similarly or even more active than HNA cells (BOUVIER; DEL GIORGIO; GASOL, 2007). Despite the uncertainties regarding the metabolic characteristics and environmental functions of those groups, several studies have addressed their spatial separation on the cytograms in terms of ecological traits (ANDRADE; GONZALEZ, 2007; MORÁN et al., 2007; ORTEGA-RETUERTA et al., 2008; VAN WAMBEKE et al., 2011).

Regarding autotrophic prokaryotes, two main groups dominate the picoplankton: Prochlorococcus and Synechococcus. Prochlorococcus are ubiquitous in euphotic zone of the tropical oceans, being considered the most abundant photosynthetic organisms on the planet (PARTENSKY et al., 1999a), and whose discovery was only made possible with the development of flow cytometry (Chisholm et al., 1988). Prochlorococcus are generally discriminated 
in the cytogram by their low red fluorescence (chlorophyll). Synechococcus populations are widely distributed in the global oceans, in environments with high nutrient input and lower salinity (PARTENSKY; BLANCHOT; VAULOT, 1999). The phycoerythrin content (orange fluorescence) is one of the key parameters that defines the distribution of Synechococcus populations on a cytogram. Different Synechococcus ecotypes can show distinct fluorescence intensities respective to their pigment signatures (OLSON; CHISHOLM; ZETTLER, 1990), due to their different phycobilisome structures (SCANLAN et al., 2009). Pico- and nanoeukaryotes are vital to global primary productivity (LI, 1994; VAULOT et al, 2008), and due to its larger cell size, they often comprise an important share of autotrophic biomass in the oceans (ZUBKOV et al., 1998b). Picoeukaryote's flow cytometric signature, due to its pigment characteristics, forms a well-defined population in the cytogram, whose cells usually ranges from $1.3 \mu \mathrm{m}$ to $2 \mu \mathrm{m}$ (SIMON et al., 1994). 

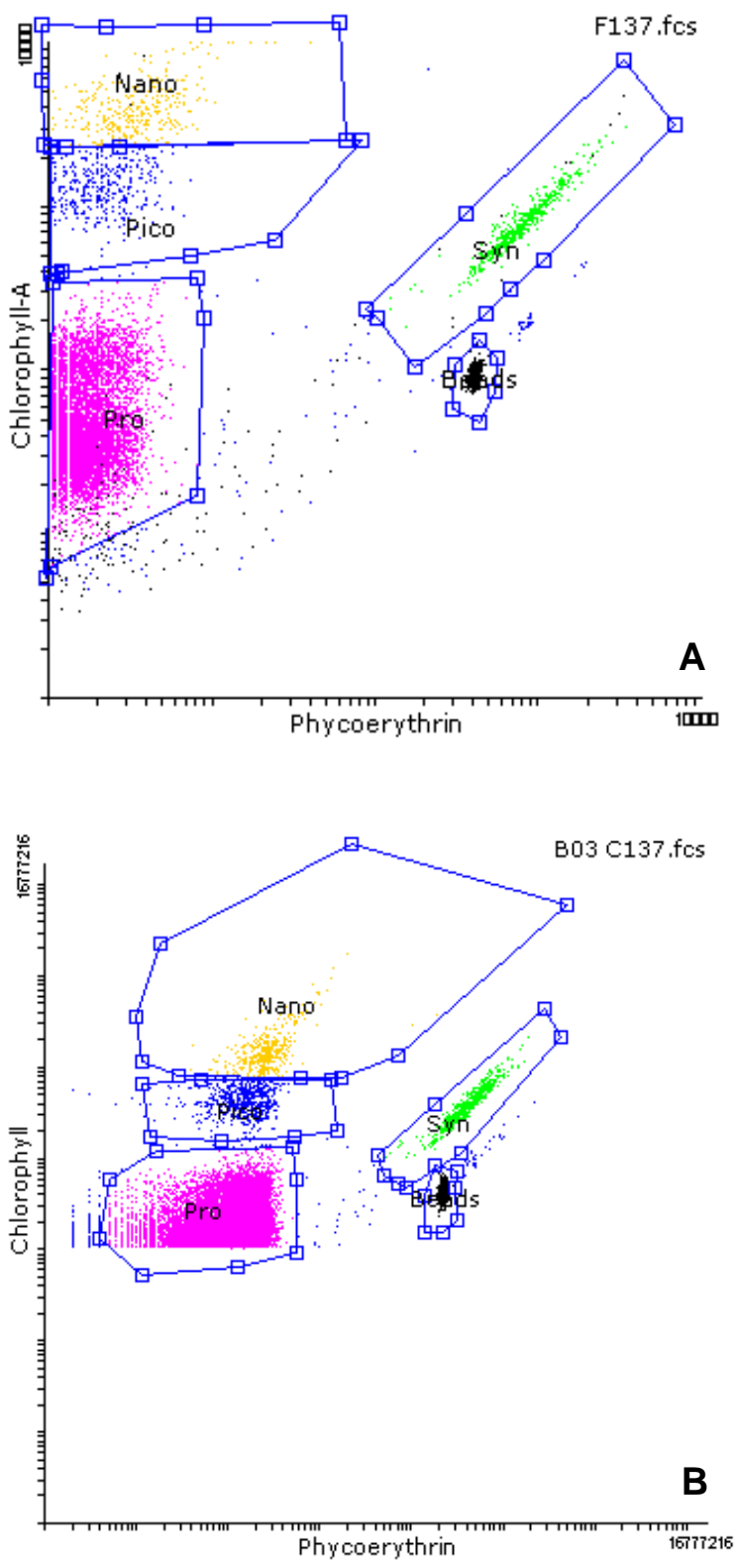

Figure 3.1. Cytograms of Phycoerythrin versus Chlorophyll of sample 137 (St. 100, 110 meters depth) from A) BD FACSCanto ${ }^{\mathrm{TM}}$ and B) BD Accuri ${ }^{\mathrm{TM}}$ C6 readings, showing the following gating patterns: Prochlorococcus (pink), Synechococcus (green), picoeukaryotes (blue) and nanoeukaryotes (yellow). Calibrations beads are marked in black. 
Table 3.1. Technical features of BD FACSCanto ${ }^{\mathrm{TM}}$ and BD Accuri ${ }^{\mathrm{TM}}$ C6 flow cytometers.

\begin{tabular}{|c|c|c|}
\hline Features & BD FACSCanto ${ }^{\mathrm{TM}}$ & BD Accuri ${ }^{\mathrm{TM}} \mathrm{C} 6$ \\
\hline Weight & $149.7 \mathrm{~kg}$ & $13.6 \mathrm{~kg}$ \\
\hline Acquisition Software & BD FACSDiva & BD Accuri C6 \\
\hline Signal Processing & Digital & Digital \\
\hline Total Laser & 2 & 2 \\
\hline Total PMT ${ }^{(\mathrm{a})}$ fluorescence & 8 & 4 \\
\hline Laser configuration & Blue/red & Blue/red \\
\hline Laser/wavelength & $\begin{array}{l}488 \mathrm{~nm}, 20 \mathrm{~mW} \text { solid } \\
\text { state } \\
633 \mathrm{~nm}, 17 \mathrm{~mW} \mathrm{HeNe}\end{array}$ & $\begin{array}{l}488 \mathrm{~nm} ; 50 \mathrm{~mW} \text { solid state } \\
640 \mathrm{~nm} ; 30 \mathrm{~mW} \text { diode }\end{array}$ \\
\hline Excitation light & Optic fiber & Direct \\
\hline Florescence sensitivity & $\begin{array}{l}\text { FITC }^{(\mathrm{b})}<100 \mathrm{MESF}^{(\mathrm{c})} \\
\mathrm{PE}^{(\mathrm{d})}<50 \mathrm{~d}\end{array}$ & $\begin{array}{l}\text { FITC }<150 \text { MESF } \\
\mathrm{PE}<100 \mathrm{MESF}\end{array}$ \\
\hline Optical alignment & Fixed alignment & Fixed alignment \\
\hline Fluidics & Positive-pressure pump & Low-pressure pump \\
\hline Sample acquisition & 18 bits / 5 decades & 24 bits / 7 decades \\
\hline Sample processing & Automated & Automated \\
\hline
\end{tabular}


With increasing popularity and a wide range of applications (WANG et al., 2010), FCM analysis is responsible for great advances in the oceanic microbial ecology, although its cost and maintenance expenses were prohibitive for many laboratories until recently (GASOL; DEL GIORGIO, 2000; VIVESREGO; LEBARON; CARON, 2000). From the first cytometry-based field study made by Olson, Vaulot \& Chisholm (1985), on-board flow cytometry has became a crucial tool in the investigation of both autotrophic and heterotrophic picoplanktonic communities (LEGENDRE; COURTIES; TROUSSELLIER, 2001). The manufacturing of low cost benchtop flow cytometers have fueled the use of this tool in the study of phytoplankton communities around the world, due to its main advantages: the easy handling, accessibility and easy transportation (a critical quality for field measurements).

To assess whether the use of flow cytometers with different features produce distinct results regarding picoplankton communities, samples from South Atlantic Ocean (comprising both nutrient and light gradients within the water column), were simultaneously analyzed in two BD flow cytometers, namely FACSCanto ${ }^{\mathrm{TM}}$ and Accuri $\mathrm{C}^{\mathrm{TM}}$ (hereafter named as CANTO and C6). Although manufactured by the same company (BD Biosciences, San Jose, CA, USA), these cytometers present distinct fluorescence excitation/detection technical features, as shown in Table 3.1. Differences in laser and optics systems can potentially impair detection resolution, influencing the accuracy of field measurements. As FCM rapidly becomes one of the most essential tools in marine microbial ecology, it is of great importance to keep track on the output data of cytometers with different manufacturing features, in order to avoid biased ecological inferences. 


\subsection{OBJECTIVES}

(A) To assess whether the use of different flow cytometers (FACSCanto ${ }^{\mathrm{TM}}$ and Accuri $\mathrm{C}^{\mathrm{TM}}$ ) produce distinct results regarding picoplankton communities.

(B) To test if an indirect correction based on red fluorescence distribution can minimize underestimation of Prochlorococcus and Synechococcus populations. 


\subsection{MATERIAL AND METHODS}

\subsubsection{Sampling}

Water samples were collected onboard the R/V "Alpha Crucis", between $31 / 10 / 2013$ and $23 / 11 / 2013$. The surveyed area was located between latitude $23^{\circ} 11^{\prime} \mathrm{S}-30^{\circ} 52^{\prime} \mathrm{S}$ and longitude $39^{\circ} 22^{\prime \prime} \mathrm{W}-49^{\circ} 09^{\prime \prime} \mathrm{W}$, up to the 3510 meters isobath, along 3 transects (TR1, TR2 and TR3), in the South West Atlantic off Brazil (Figure 3.2). Details regarding ecological data from pico- and nanoplankton communities obtained in this cruise can be found in Chapter 1. The sampling strategy comprised 5 depths per station within the euphotic zone on TR1 and TR2, as well as 12 surface samplings in TR3, in a total of 102 samples. Except for TR3 samples, which were collected using a polycarbonate bucket, seawater samples were collected with $12 \mathrm{~L}$ Niskin bottles attached to a Seabird $^{\circledR}$ CTD-rosette system (Sea-Bird Electronics, Bellevue, WA, USA), divided into cryotubes, preserved with $0.1 \%$ glutaraldehyde (final concentration), kept incubating for 10 minutes in the dark, flash-frozen in liquid nitrogen and stored at $-80^{\circ} \mathrm{C}$ until analysis. 


\subsubsection{Flow Cytometry Analysis}

We used for the analysis in this study a BD FACSCanto ${ }^{\mathrm{TM}}$ flow cytometer with two lasers: blue (488 nm, air-cooled, $20 \mathrm{~mW}$, solid state) and red (633 nm, 17-mW, HeNe). Its optical characteristics of excitation and capture grant it high accuracy and reproducibility, but it presents disadvantages in terms of size (61 x $91 \times 64 \mathrm{~cm}$ ) and cost. The BD Accuri ${ }^{\mathrm{TM}}$ C6 is equipped with lasers of $488 \mathrm{~nm}$ (blue) and $640 \mathrm{~nm}$ (red), being able to analyze up to 6 parameters: FSC (forward scatter), SSC (side scatter) and four fluorescences. Its main advantages are the easy handling, accessibility (relatively low cost) and easy transportation (a critical quality for field measurements).

In order to visualize particles that do not present autofluorescence (heterotrophic bacteria), and differentiate them from abiotic particles, we added SYBR Green ${ }^{\circledR}$ dye to the samples (1:10000, final concentration) (Molecular Probes, Leiden, Netherlands). The calibration for counting was made with 0.95 $\mu \mathrm{m}$ beads. For natural fluorescence, it was used the following settings: fast sample rate; limit of $200 \mu \mathrm{L}$ and threshold of 700 on FL3-H (red fluorescence); for non-autofluorescent cells, it was used medium sample rate, limit of $60 \mu \mathrm{L}$ and threshold of 700 on FL1-H (SYBR fluorescence). The cytograms were analyzed in the Flowing Software 2.5 (http://www.flowingsoftware.com). Cells were counted simultaneously in both cytometers to avoid any possible bias induced by manipulation.

In order to minimize underestimation of Prochlorococcus and Synechococcus events near surface due to photoacclimation, we applied the correction factor described by Crosbie \& Furnas, (2001), with modifications. 
Assuming that the red fluorescence distribution of these populations have a normal or Gaussian shape (CROSBIE; FURNAS, 2001; SHAPIRO, 2003), we designed a $\mathrm{R}$ routine which prospects and corrects samples based on the presence of a mode (highest frequency value) on the histogram. Three situations were addressed, as it follows: 1) when the mode was not visible, samples were considered to be within the detection noise, without the possibility of counting nor correction. Hence, this samples were ignored and removed from the dataset (e.g. Figure 3.6 - G) and assigned as 'cells in noise'; ii) when the mode was visible, but the normal distribution was incomplete, the abundance of each population was calculated as the double of the right part of the histogram, from its highest frequency value (mode) and samples were assigned as 'correction' (e.g. Figure 3.6 - A); iii) when the mode was visible, along with a complete continuous distribution, no correction was performed and the initial output value was kept ('no correction' samples) (e.g. Figure $3.6-\mathbf{C}$ ). It is necessary to note that the automatic correction described above needs some degree of visual confirmation, specially on deeper samples with low cell numbers. 


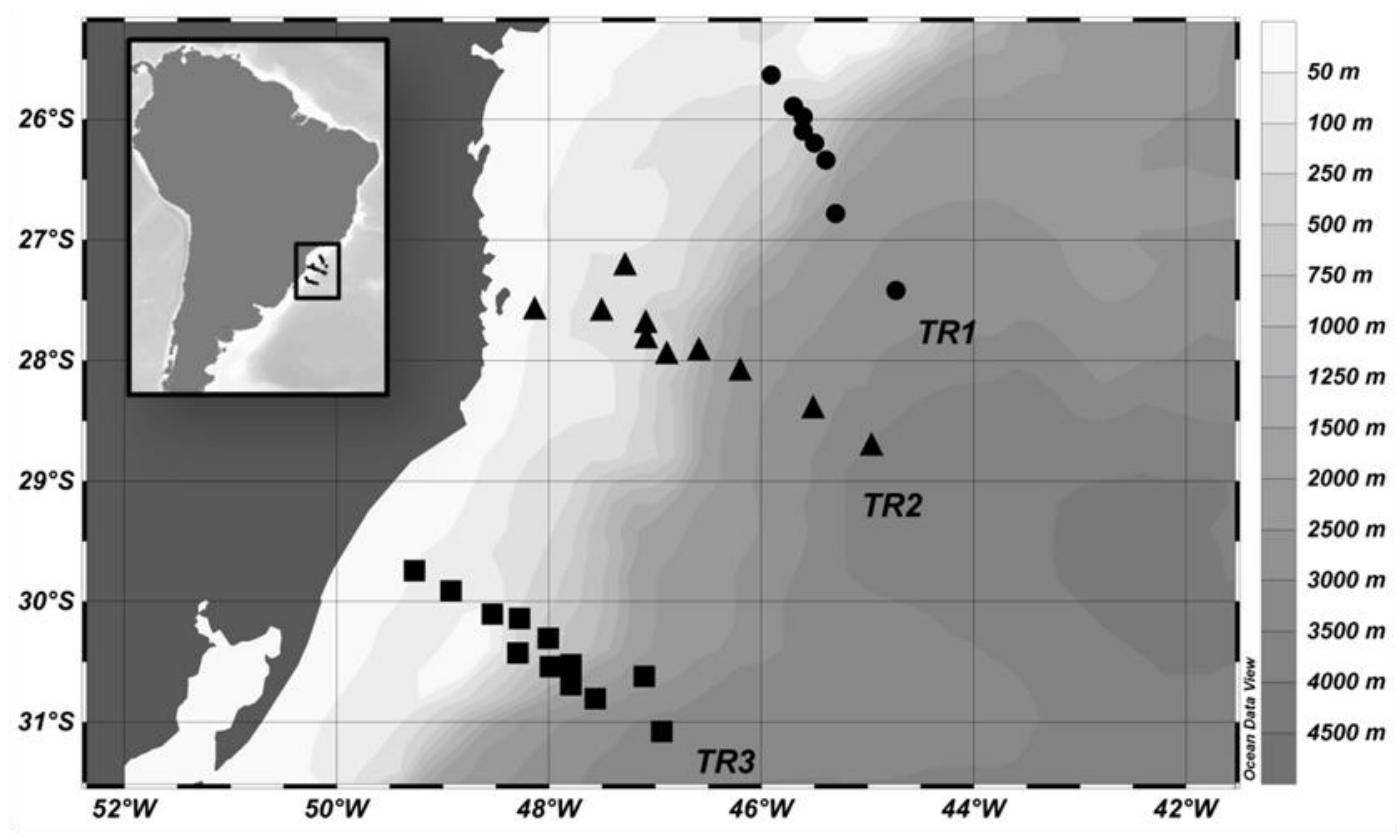

Figure 3.2. Location of sampling stations in the SAO off Brazil. Profiles: transect 1 (TR1, shaded circles) ; transect 2 (TR2, shaded triangles) and surface sampling, transect 3 (TR3, shaded squares). The color bar in the left indicates bottom depths. 


\subsection{RESULTS}

\subsubsection{HNA and LNA bacteria}

High Nucleic Acid and Low Nucleic Acid bacterial populations were consistently distinguished with both cytometers. Measurements of these populations were within the resolution threshold in both CANTO and C6 on all sampling points, and the correlation between each data acquisition was greatly fitting (Figure 3.5 - A, B). HNA abundance maxima measurements were $686 \times 10^{3}$ cells. $\mathrm{ml}^{-1}$ and $624 \times 10^{3}$ cells. $\mathrm{ml}^{-1}$ with CANTO and C6, respectively, obtained in the same sampling point (St.133, Table S3.1). The coefficient of determination was $R^{2}=0.854(y=0.852 x+9449)$. The same was observed for LNA bacteria, whose mean abundances were $464 \times 10^{3}$ cells. $\mathrm{ml}^{-1}$ and $414 \times 10^{3}$ cells. $\mathrm{ml}^{-1}$ for CANTO and C6 measurements, respectively, with $\mathrm{R}^{2}=0.89(\mathrm{y}=$ 0.934x - 20104), as shown in Figure 3.5 (B).

\subsubsection{Prochlorococcus and Synechococcus}

Prochlorococcus and Synechococcus detection signals are overlooked with $\mathrm{C} 6$ when fluorescence intensity is below $1.9 \times 10^{2}$, being this effect more severe in the former than in the latter group. Figure $\mathbf{3 . 3}$ and $\mathbf{3 . 4}$ show examples of raw (not normalized) red fluorescence distribution data of Prochlorococcus and Synechococcus between samples of different depths on CANTO and C6, respectively. CANTO readings (Figure $\mathbf{3 . 3}$ - A, B) tend to present a 
characteristic Gaussian 'bell shaped' distribution, whilst C6 measurements are abruptly absent below the cited fluorescence threshold (Figure 3.4 - A, B).

The C6 limitations to fully resolve populations was observed more often on surface samples, and was also observed in CANTO measurements. Figure 3.6 shows examples of discriminated depth profiles of normalized (for details see $\mathrm{R}$ code, supplementary material) red fluorescence distribution of Prochlorococcus and Synechococcus on the different equipments, along with a depth profile with the respective cell abundance. C6 readings were particularly impaired above 50 meters depth, for both picocyanobacterial groups (Figure 3.6 - G:K, S:W), although its effect extends to deeper layers of the water column for Prochlorococcus (Figure 3.6 - L, X).

Regarding Prochlorococcus, the coefficient of determination between both equipments was high when considering only 'no correction' $\left(R^{2}=0.939, y\right.$ $=0.754 x+1056)$ and 'correction' points $\left(R^{2}=0.963, y=0.750 x+1563\right)$ (Figure 3.5 - C). Outlier points refer to samples where, even though the correction was possible, the accuracy was still very weak between both equipments (represented by open triangles in Figures 3.5, 3.7 and 3.8). Those points were excluded from the coefficient of determination calculation $\left(R^{2}\right)$. 


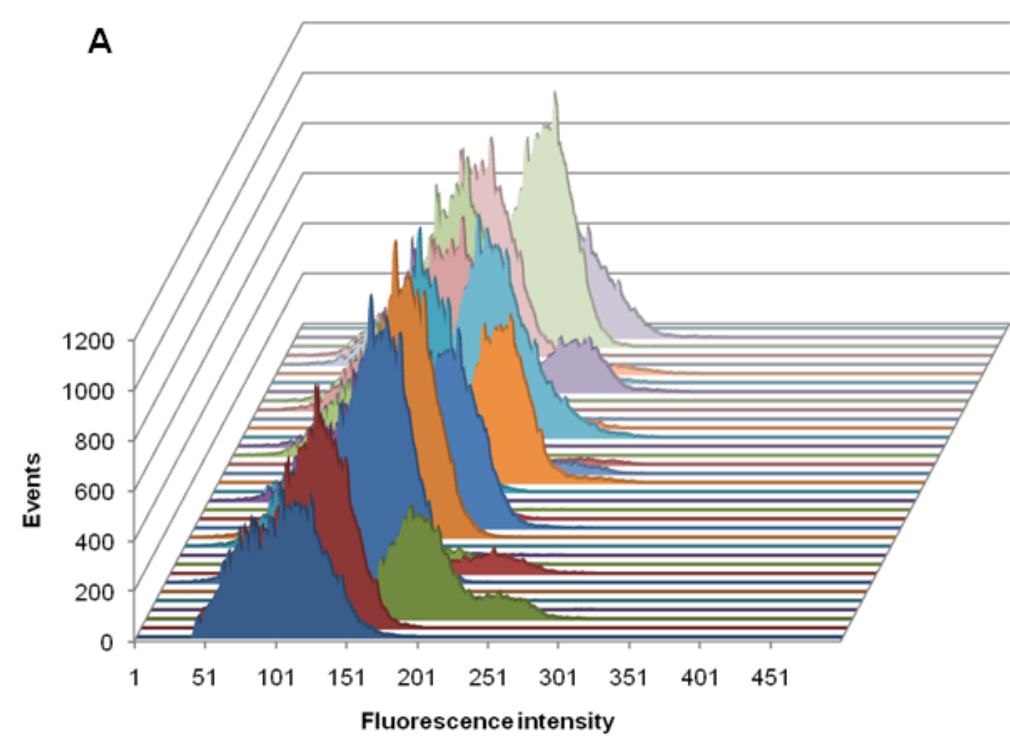

- 135_CANTO PRO $5 \mathrm{~m}$ -136_CANTOPRO-50m $=137$ CANTO_PRO_ $110 \mathrm{~m}$ - 138_CANTOPRO $130 \mathrm{~m}$ -139_CANTOPPRO $170 \mathrm{~m}$ =140_CANTOPRO $5 \mathrm{~m}$ -141_CANTO_PRO-60m - $142{ }^{-}$CANTOPRO- $110 \mathrm{~m}$ $=143$ CANTOPRO $130 \mathrm{~m}$ -144CANTOPRO $170 \mathrm{~m}$ $=145$ CANTO-PRO- $5 \mathrm{~m}$ $=146$ CANTO-PRO $65 \mathrm{~m}$ $=147^{-}$CANTOPRO $100 \mathrm{~m}$ $1148^{-}$CANTOPRO $150 \mathrm{~m}$ $149^{-}$CANTO PRO $180 \mathrm{~m}$ - $150^{\circ}$ CANTO PRO- $5 \mathrm{~m}$ - 151 CANTO-PRO- $65 \mathrm{~m}$ 152 CANTOPRO $100 \mathrm{~m}$ 153 CANTO 154 CANTO PRO $180 \mathrm{~m}$ 155 CANTOPRO 156 158 CANTO 158 CANTO-PRO- $130 \mathrm{~m}$ 159 CANTOPRO 161_CANTO_PRO_5m 161_CANTO_PRO_60m - 162_CANTO_PRO_90m 163_CANTO_PRO_ $140 \mathrm{~m}$ 164_CANTO_PRO_170m 165_CANTO_PRO_5m 166_CANTO_PRO_60m 167_CANTO_PRO_80m 168_CANTO_PRO_100m 169_CANTO_PRO_160m

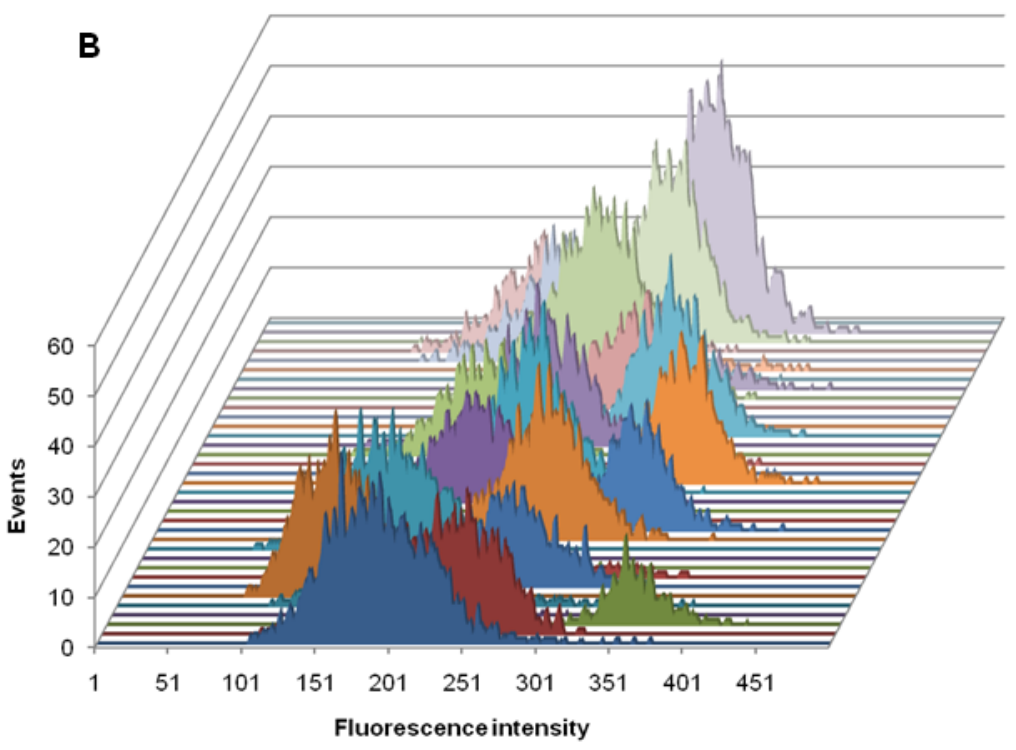

-135_CANTO_SYN_5m -136_CANTO_SYN_50m $=137$ CANTO_SYN_ $110 \mathrm{~m}$ - 138_CANTO_SYN_130m -139_CANTO_SYN_170m -140_CANTO_SYN_5m - 141_CANTO_SYN_60m - 142_CANTO_SYN_ $110 \mathrm{~m}$ -143_CANTO_SYN_ $130 \mathrm{~m}$ -144_CANTO_SYN_170m -145_CANTO_SYN_5m -146_CANTO_SYN $65 \mathrm{~m}$ -147_CANTO_SYN_100m -148 CANTO SYN $150 \mathrm{~m}$ $=149$ CANTO SYN $180 \mathrm{~m}$ -150_CANTO SYN $5 \mathrm{~m}$ $=151$ CANTOSSYN $65 \mathrm{~m}$ $=152$ CANTOSSY $100 \mathrm{~m}$ $=153$ CANTO SYN $150 \mathrm{~m}$ 154 CANTO SYN $180 \mathrm{~m}$ 155 CANTO SYN $5 \mathrm{~m}$ $156{ }^{-}{ }^{-}$CANTO ${ }^{-} Y^{-} 60 \mathrm{~m}$ $157^{-}$CANTO SYN $^{-} 100 \mathrm{~m}$ $158^{-}$CANTO SYN $130 \mathrm{~m}$ $159^{-}$CANTO SYN $190 \mathrm{~m}$ $160^{-}$CANTO SYN $5 \mathrm{~m}$ 161 CANTO SYN $60 \mathrm{~m}$ 162 CANTO SYN 162 CANTO 163_CANTO_SY $140 \mathrm{~m}$ 165 CANTO 166 CANTO166 CANTOSY -60m CANT 169 CANTO_SYN_ $160 \mathrm{~m}$

Figure 3.3. Examples of red fluorescence distribution (number of events versus fluorescence intensity) from different depths of $\mathbf{A}$ ) Prochlorococcus and B) Synechococcus recorded with BD FACSCanto ${ }^{\mathrm{TM}}$. Samples and their respective depths are described in the right. 


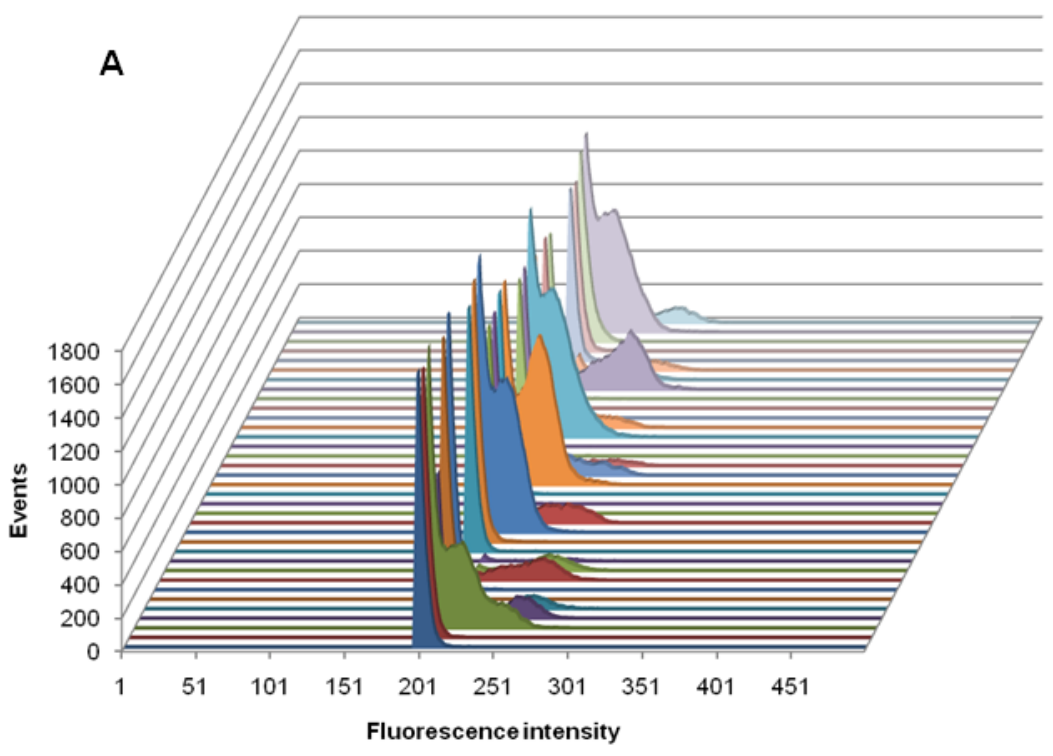

-135_C6_PRO_5m -136_C6_PRO_50m 137_C6_PRO_ $110 \mathrm{~m}$ - 138_C6_PRO_ $130 \mathrm{~m}$ -139_C6_PRO_170m -140_C6_PRO_5m -141_C6_PRO_60m -142_C6_PRO_110m =143_C6_PRO_130m -144_C6_PRO_170m $=145$ C6 6 PRO_ $5 \mathrm{~m}$ $=146$ C6_PRO $65 \mathrm{~m}$ -147 C6 6 PRO $100 \mathrm{~m}$ -148_C6-PRO_150m $=149$ C6 6 PRO $180 \mathrm{~m}$ -150_C6_PRO_5m $=151 \mathrm{C} 6 \mathrm{PRO}-65 \mathrm{~m}$ 152 C6 PRO $100 \mathrm{~m}$ 153 C6 PRO $150 \mathrm{~m}$ $154-\mathrm{CR}-180 \mathrm{~m}$ $155^{-} 6 \mathrm{PRO}-5 \mathrm{~m}$ $=156 \mathrm{C} 6 \mathrm{PRO}-60 \mathrm{~m}$ $=157$ C6PRO $100 \mathrm{~m}$ 158 6 PRO $130 \mathrm{~m}$ 159 161 C6 PRO $6 \mathrm{~m}$ 162 163 PRO $140 \mathrm{~m}$ 164_C6PRO_ $140 \mathrm{~m}$ 164 - 6 PRO $170 \mathrm{~m}$ 165 167 - 167 C6-PRO_ $80 \mathrm{~m}$ 168_C 169_C6_PRO_160m

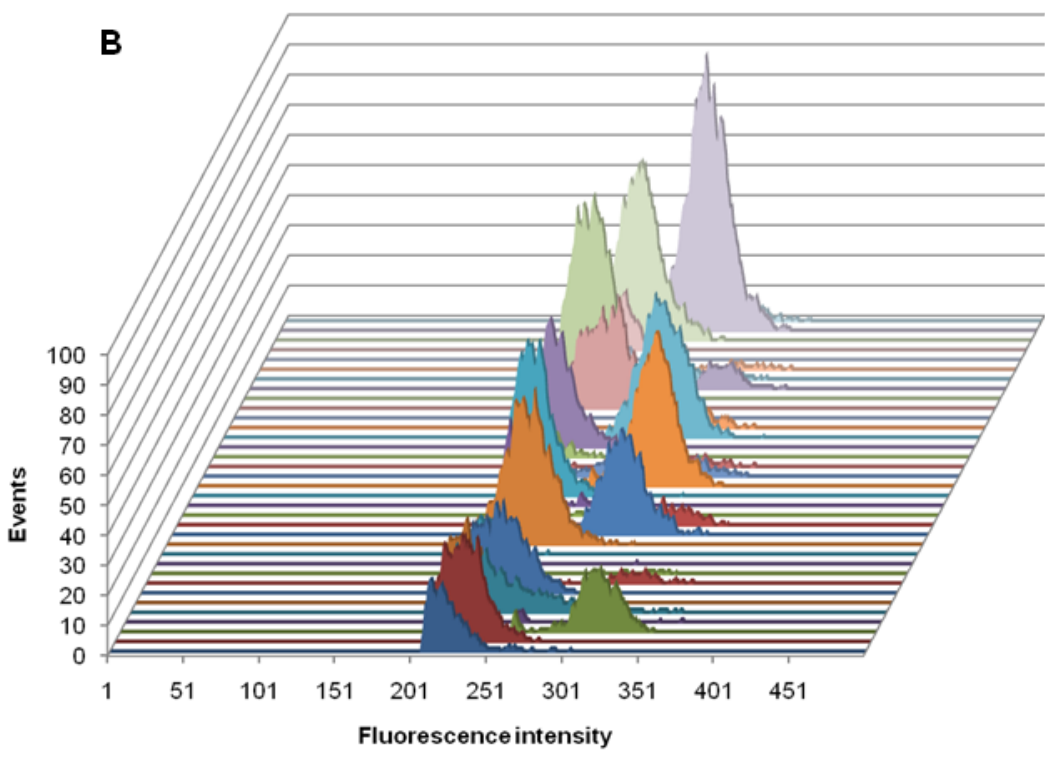

-135_C6_SYN_5m -136_C6_SYN_50m -137_C6_SYN_110m -138_C6_SYN_130m -139_C6_SYN_170m $=140$ C6_SYN_5m -141_C6_SYN_60m - $142{ }^{-} \mathrm{C}_{-} \mathrm{SYN}^{-} 110 \mathrm{~m}$ $=143-C 6-S Y N-130 \mathrm{~m}$ -144_C6_SYN_ $170 \mathrm{~m}$ -145_C6_SYN_5m $=146$ C6 6 SYN $65 \mathrm{~m}$ -147_C6_SYN $100 \mathrm{~m}$ -148_C6_SYN $150 \mathrm{~m}$ $=149{ }^{-} 6{ }^{-}$SYN $^{-} 180 \mathrm{~m}$ $=150^{-} 6^{-}{ }^{-}{ }^{-}{ }^{-} 5 \mathrm{~m}$ $=1511^{-}{ }^{-}{ }^{-}{ }^{-}-65 \mathrm{~m}$ $=152^{-} \mathrm{C}^{-} \mathrm{SYN}^{-} 100 \mathrm{~m}$ $=1533^{-} 6^{-} S^{-1}-150 \mathrm{~m}$ $=154^{-} \mathrm{CG}^{-} \mathrm{SYN}^{-} 180 \mathrm{~m}$ $=155^{-}{ }^{-}{ }^{-}{ }^{-}-5 \mathrm{~m}$ - 156 C6-SYN-60m $-157^{-} \mathrm{C6}^{-} \mathrm{SYN}-100 \mathrm{~m}$ $158{ }^{-}{ }^{-}{ }^{-130 m}$ $159-\mathrm{CO}^{-}-10 \mathrm{~m}$ $160^{-} 6^{-}{ }^{-} \mathrm{m}$ 161 6 162_C $=162{ }^{-}{ }^{-}$ 163 166 167 169_C6_SYN_160m

Figure 3.4. Examples of red fluorescence distribution (number of events versus fluorescence intensity) from different depths of A) Prochlorococcus and B) Synechococcus recorded with BD Accuri ${ }^{\mathrm{TM}} \mathrm{C} 6$. Samples and their respective depths are described in the right. 

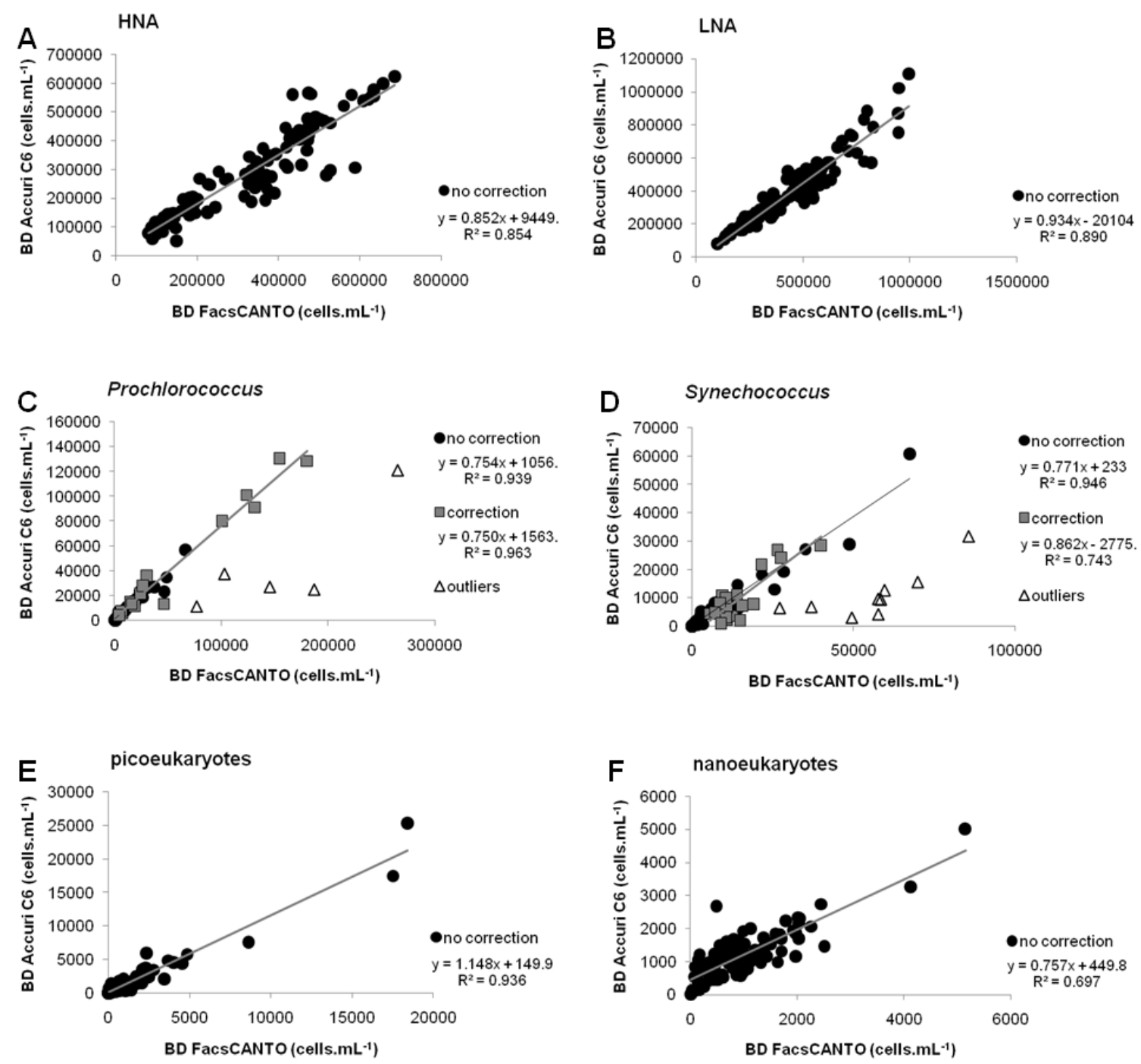

Figure 3.5. Relationship between abundance measurements performed with BD Accuri ${ }^{\mathrm{TM}} \mathrm{C} 6$ e BD FACSCanto ${ }^{\mathrm{TM}}$ (in cells. $\mathrm{mL}^{-1}$ ): (A) HNA bacteria; (B) LNA bacteria; (C) Prochlorococcus; (D) Synechococcus; (E) picoeukaryotes and (F) nanoeukaryotes. Regarding correction in red fluorescence distribution, points are marked as: 'no correction': black shaded circles, 'correction': grey shaded squares; outliers: open triangles. The coefficient of determination and the equation are indicated on each graphic. The regression line is marked in grey for points with no correction and in black for 'correction' samples, although being totally superimposed in Prochlorococcus regression (C). 

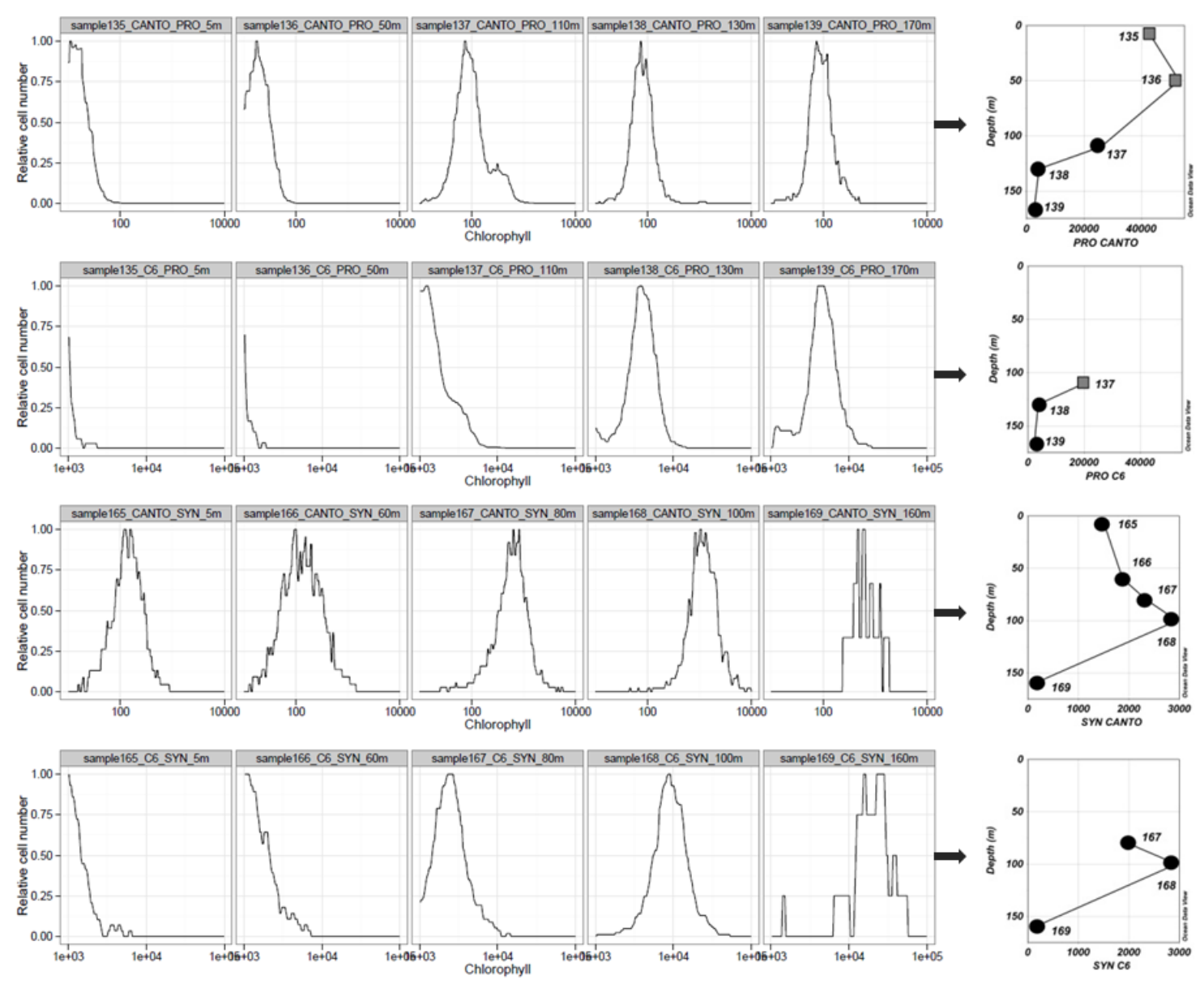

Figure 3.6. Examples of discriminated depth profiles (St. 100 and St. 114) of normalized red fluorescence distribution (chlorophyll versus relative cell number) and respective cell abundance of Prochlorococcus (A:L) and Synechococcus (M:X) on BD FACSCanto ${ }^{\mathrm{TM}}$ and BD Accuri ${ }^{\mathrm{TM}}$ C6. In the depth profiles (F, L, R, X), black shaded represents 'no correction' samples; grey shaded squares indicates 'correction' samples; samples within the noise were suppressed. 
The maximum abundances of Prochlorococcus were $291 \times 10^{3}$ cells. $\mathrm{mL}^{-1}$ with CANTO and $98 \times 10^{3}$ cells. $\mathrm{mL}^{-1}$ with $\mathrm{C} 6$ (Figure 3.7). The mean abundance obtained with CANTO $\left(105 \times 10^{3}\right.$ cells. $\left.\mathrm{mL}^{-1}\right)$ was approximately one order of magnitude higher than the one obtained with C6 $\left(14 \times 10^{3}\right.$ cells. $\left.\mathrm{mL}^{-1}\right)$, considering only the $\mathrm{C} 6$ points without underestimation ('no correction' sampling points, Table 3.2). In the sample where it was registered the maximum abundance with CANTO (St.101, 60 meters depth) there was no Prochlorococcus detection by C6 (Figure 3.7).

From the total 102 sampling points measured with CANTO for Prochlorococcus, 74 samples were assigned as 'no correction' and 27 as 'correction', including several sampling points in the top layers of the water column (Figure 3.7 - A, B). The majority of C6 readings (55 samples) were below the detection limit (with no visible mode in red fluorescence distribution), without any possible inferences about Prochlorococcus abundance (Table 3.2, Figure 3.7 - C, D).

The coefficient of determination in Synechococcus measurements between both equipments was high only on 'no correction' sampling points $\left(\mathrm{R}^{2}=\right.$ $0.946, y=0.771 x+233)$. Measurements with correction had a relatively weak correlation $\left(R^{2}=0.743, y=0.862 x-2775\right)$, and nine points were assigned as 'outliers' (Figure 3.5 - D). Synechococcus counting ranged from 48 cells. $\mathrm{mL}^{-1}$ to $81 \times 10^{3}$ cells. $\mathrm{mL}^{-1}$ with CANTO and from 25 cells. $\mathrm{mL}^{-1}$ to $60 \times 10^{3}$ cells. $\mathrm{mL}^{-1}$ with C6. Neither the maxima nor the minima of Synechococcus abundance were registered in the same sampling point. The highest abundance was observed in a superficial sample with CANTO (St. 92, 5 meters depth) and at 50 meters depth with C6 (St.96) (Figure 3.8 - A, D). Only one sample in Synechococcus 
readings from CANTO was subjected to correction, and none was below the detection limit of the equipment. On its turn, 29 samples needed correction (9 outliers) and 15 samples were within the noise on C6 measurements (Figure 3.8 C, D, Table 3.2).

\subsubsection{Pico- and nanoeukaryotes}

The average abundance obtained for pico- and nanoeukaryotes populations were $1.3 \times 10^{3}$ cells. $\mathrm{mL}^{-1}$ and $0.9 \times 10^{3}$ cells. $\mathrm{mL}^{-1}$ with CANTO and $1.6 \times 10^{3}$ cells. $\mathrm{mL}^{-1}$ and $1.1 \times 10^{3}$ cells. $\mathrm{mL}^{-1}$ with C6. All maxima (St. 92, 30 meters depth) and minima (St. 97, 190 meters depth) were obtained in the same sampling points, for both pico- and nanoeukaryotes. The correlation between measurements from distinct equipments was different for both groups, with $\mathrm{R}^{2}=$ $0.936(y=0.815 x-37.57)$ for picoeukaryotes and $R^{2}=0.697(y=0.919 x-$ 127.3) for nanoeukaryotes (Figure 3.5 - E, F).

Table 3.2. Number of samples assigned as 'correction', 'no correction' and 'cells in noise' for each picocyanobacterial group and equipment tested.

\begin{tabular}{llll}
\hline & Correction & No correction & Cells in noise \\
\hline CANTO - Prochlorococcus & 27 & 74 & 01 \\
C6 - Prochlorococcus & 20 & 27 & 55 \\
CANTO - Synechococcus & 01 & 101 & 0 \\
C6 - Synechococcus & 29 & 58 & 15 \\
\hline
\end{tabular}


TR1

A PRO CANTO
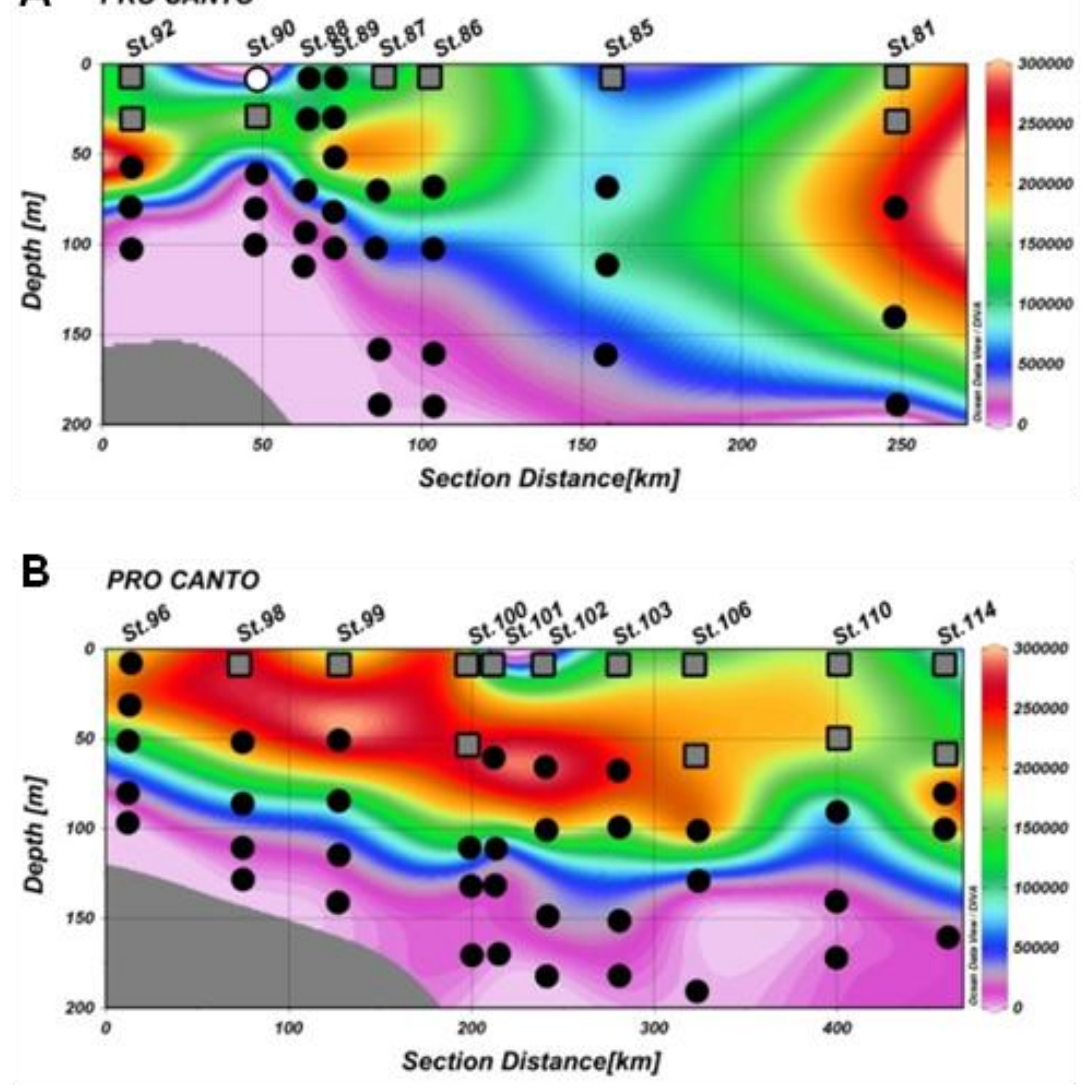

TR2
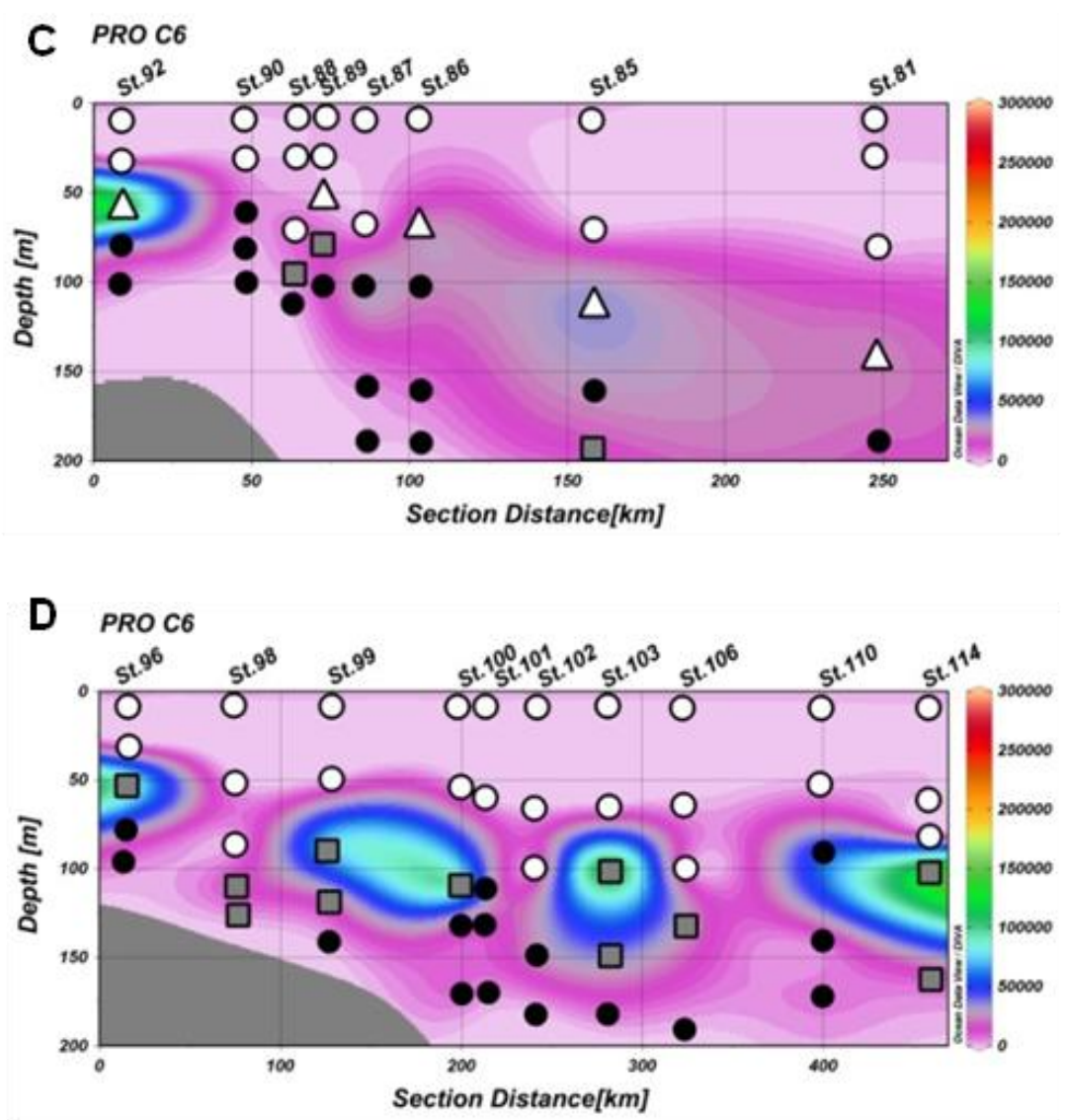

Figure 3.7. Comparison between measurements with BD FACSCanto ${ }^{\mathrm{TM}}(\mathbf{A}, \mathbf{B})$ and $\mathrm{BD}$ Accuri ${ }^{\mathrm{TM}} \mathrm{C} 6(\mathbf{C}, \mathbf{D})$ regarding the vertical abundance distribution (in cells. $\mathrm{mL}^{-1}$ ) of Prochlorococcus; numbers in the top indicate sampling stations; sampling points are marked as: 'no correction': black shaded circles, 'correction': grey shaded squares; outliers: open triangles, 'cells in noise': open circles. 
TR1

A SYN CANTO

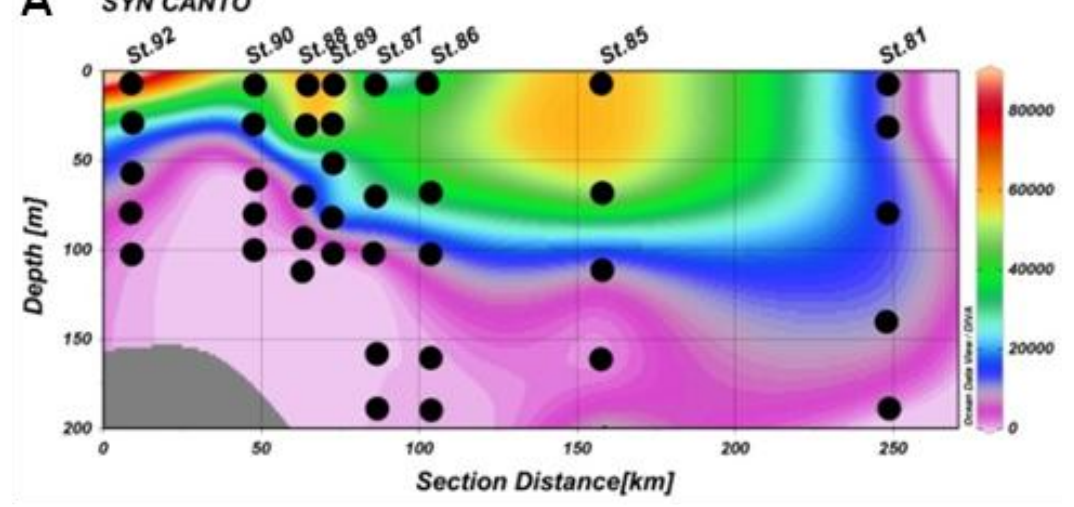

B SYN CANTO

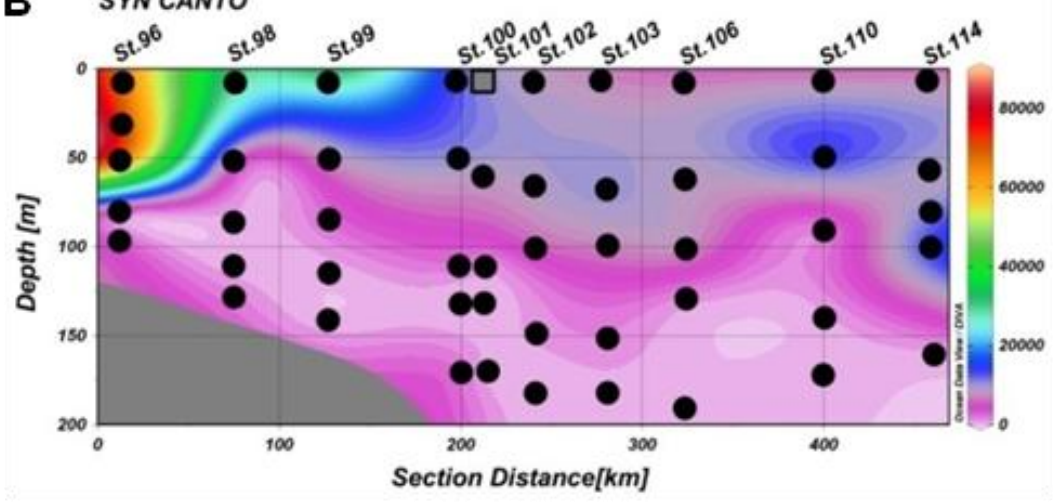

TR2
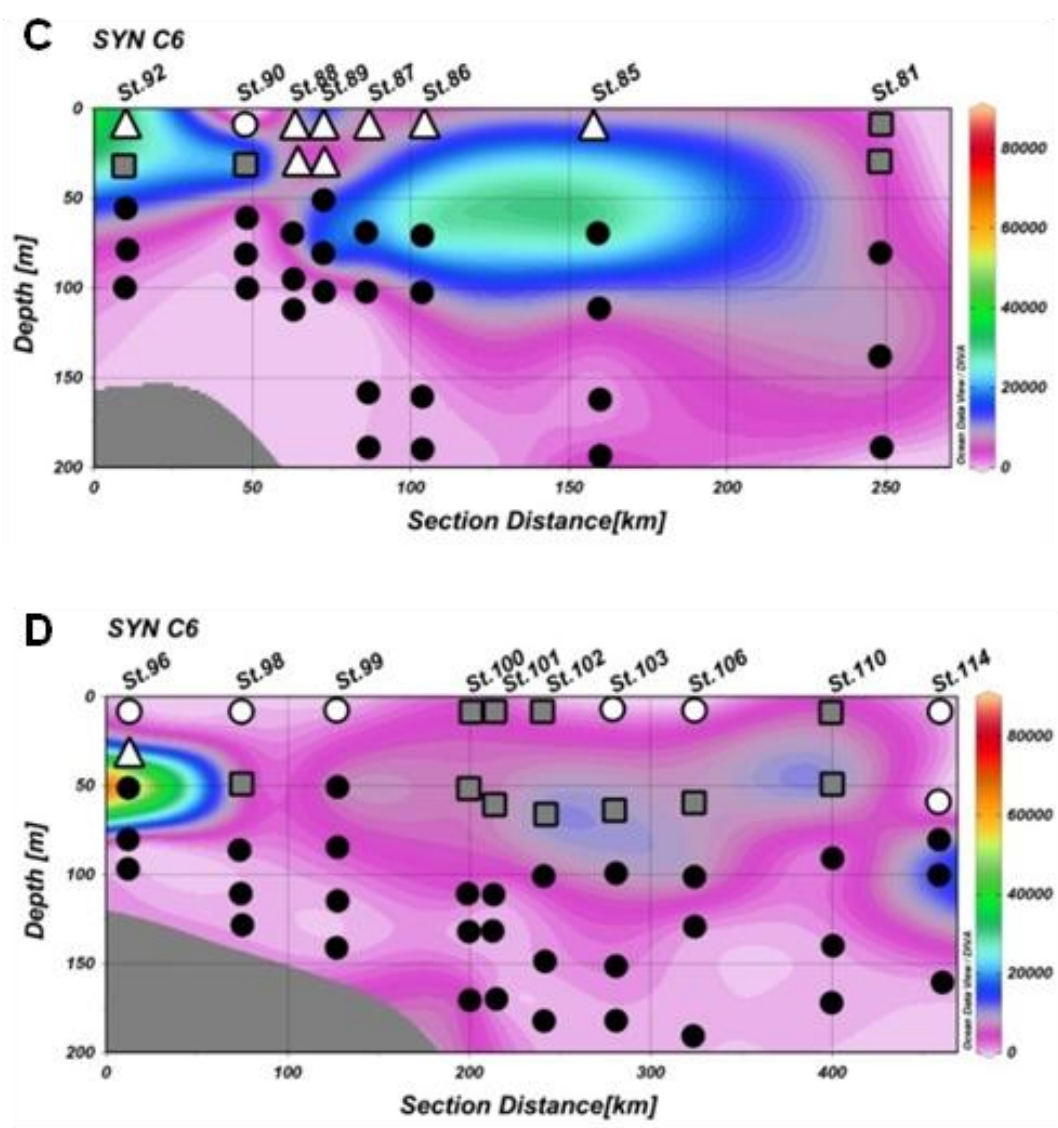

Figure 3.8. Comparison between measurements with BD FACSCanto ${ }^{\mathrm{TM}}(\mathbf{A}, \mathbf{B})$ and $\mathrm{BD}$ Accuri ${ }^{\mathrm{TM}} \mathrm{C} 6(\mathbf{C}, \mathbf{D})$ regarding the vertical abundance distribution (in cells. $\mathrm{mL}^{-1}$ ) of Synechococcus; numbers in the top indicate sampling stations; sampling points are marked as: 'no correction': black shaded circles, 'correction': grey shaded squares; outliers: open triangles, 'cells in noise': open circles. 


\subsection{DISCUSSION}

The accuracy of a given flow cytometer reflects its capacity to deliver data near 'true' values (SHAPIRO, 2003), i.e., its ability to represent properly the ecological structure found in the environment. The study of picoplanktonic communities by flow cytometry is complex, since each population and their distinctive cell features, related to the parameters captured by FCM, may change with depth and nutrient input (VAULOT; MARIE, 1999). From the six planktonic groups studied here, three were well resolved by both CANTO and C6 flow cytometers: HNA and LNA heterotrophic bacteria and autotrophic picoeukaryotes. HNA and LNA fractions were easily separated with both equipments, and the correlation between measurements was highly satisfactory $\left(R^{2}=0.9\right)$, indicating that the use of a fluorescent dye for bacterial abundance provides a standardized method for counting, allowing readings to fall within the resolution limits of both tested equipments (Figure 3.5 - A, B). Autofluorescent picoeukaryotic populations were also well represented regardless of the equipment used $\left(R^{2}=0.9\right.$, Figure 3.5 - E).

Despite its higher resolution, autotrophic nanoplanktonic cells counting was lower in CANTO readings (Figure 3.5 - F). The data acquisition features of C6, on which fluorescence signals are recorded on a seven-decade logarithmic scale (versus a five-decade system in CANTO) (Figure 3.1, Table 3.1), enable the detection of larger cells from the autotrophic nanoplankton, decreasing the observed correlation between instruments within this group $\left(R^{2}=0.7\right)$. 
To overcome the problem of low sensitivity flow cytometers, both direct and indirect approaches to infer Prochlorococcus abundance were developed, such as changes in the cytometer optical apparatus to improve excitation/acquisition (DUSENBERRY; FRANKEL, 1994; PARTENSKY; HESS; VAULOT, 1999) and the use of mathematical inferences (CROSBIE; FURNAS, 2001; ZUBKOV et al., 1998a). As we could observe in the present study, indirect approaches used to correct the abundance of populations based on Gaussian red fluorescence distribution are not enough to fully compensate low sensibility readings, even in samples where the mode is visible. The main discrepancies between the readings of the tested equipments were observed on picocyanobacteria populations (Prochlorococcus and Synechococcus), mostly in the first 100 meters of the water column (Figure 3.7 and 3.8). The top layers of the oceans receive a massive input of visible light energy and UV radiation, which can be deleterious to prokaryotic phytoplankton cells, slowing both growth and DNA synthesis (VAULOT; MARIE, 1999). In parallel, due to abundant sunlight, the concentration of photosynthetic pigments (e.g., chlorophyll, phycoerythrin) per cell decreases (OLSON; CHISHOLM; ZETTLER, 1990; SOSIK; CHISHOLM; OLSON, 1989), creating 'dim' populations, whose identification is difficult if a low sensitivity equipment is used, as can be easily observed in the comparison of profiles from Figure 3.7 and 3.8. The issue regarding FCM limitations on data acquisition of natural fluorescence of nearsurface, low chlorophyll populations have been addressed before (DUSENBERRY; FRANKEL, 1994; PARTENSKY; HESS; VAULOT, 1999).

Prochlorococcus endures a wide acclimation on its pigment content throughout the light intensity gradient in the water column, up to a fifty fold 
increase (MARIE; SIMON; VAULOT, 2005). In flow cytometers with lower resolution, the signal from near-surface Prochlorococcus cells (with lower pigment concentration) tend to be merged with background noise in the cytogram, making a proper counting impracticable. Although corrections were needed in Prochlorococcus readings performed with CANTO, especially in the surface samplings down to 70 meters depth (Figure 3.7 - A, B), impairment was sensibly less severe than with C6 (Figure 3.7 - C, D). The detection of Prochlorococcus from surface to the deep chlorophyll maximum layer (around 50-70 meters depth) was markedly decreased by the use of the $\mathrm{C6}$, with total absence or extremely low numbers in most of profiles (Figure 3.7 - C, D). Most Prochlorococcus populations present on these layers cannot be subjected to correction, since the mode is indistinguishable from the noise in the C6 readings. This effect seems to reach deeper layers towards offshore, probably due to the far-reaching penetration of light in oligotrophic waters (Figure 3.7 C).

Although Synechococcus counts with CANTO were higher than the ones with C6 (Figure 3.8), the differences were much milder when compared to Prochlorococcus, and mostly constrained to the upper 50 meters of the water column. Nonetheless, this decreasing effect means that the equipment used may have a high impact on the prospect of picoplanktonic structure where Synechococcus is more abundant, since this group is known to thrive precisely in the well-lit, top layers of the oceans (PARTENSKY; BLANCHOT; VAULOT, 1999). In addition, all of the points where the abundance correction produced outlier values (Figure 3.5 - D) were dominated by Synechococcus (Figure 3.8 C), which highlights the fact that the impairment by the use of low resolution 
cytometers is even more severe when the population concentration is higher. It is possible that the sharp decrease in Synechococcus abundance in the top layers of the water column observed in some studies (VAULOT; MARIE, 1999) could be milder if a cytometer with a higher detection limit was available. 


\subsection{CONCLUSIONS}

The increasing affordability of benchtop flow cytometers often comes with disadvantages in equipment's features, such as lower detection limits. The comparison between studies of phytoplankton communities by flow cytometry should take into account the equipment used, particularly in approaches involving populations of Prochlorococcus and Synechococcus, whose low chlorophyll concentration per cell can lead to the underestimation of its abundance due to photoacclimation in oceanic environments with high light incidence. 


\subsection{REFERENCES}

ANDRADE, L. et al. Flow cytometry assessment of bacterioplankton in tropical marine environments. Journal of Microbiological Methods, v. 55, p. 841-850, 2003.

ANDRADE, L.; GONZALEZ, A. Distribution of HNA and LNA bacterial groups in the Southwest Atlantic Ocean. Brazilian Journal of Microbiology, v. 38, p. 330-336, 2007.

BOUVIER, T.; DEL GIORGIO, P. A.; GASOL, J. M. A comparative study of the cytometric characteristics of High and Low nucleic-acid bacterioplankton cells from different aquatic ecosystems. Environmental Microbiology, v. 9, n. 8, p. 2050-2066, 2007.

CROSBIE, N.; FURNAS, M. Abundance, distribution and flow- cytometric characterization of picophytoprokaryote populations in central $\left(17^{\circ} \mathrm{S}\right)$ and southern $\left(20^{\circ} \mathrm{S}\right.$ ) shelf waters of the Great Barrier Reef. Journal of plankton research, v. 23, n. 8, p. 809-828, 2001.

DUSENBERRY, J. A.; FRANKEL, S. L. Increasing the sensitivity of a FACScan flow cytometer to study oceanic picoplankton. American Society of Limnology and Oceanography, v. 39, n. 1, p. 206-209, 1994.

GASOL, J. M.; DEL GIORGIO, P. A. Using flow cytometry for counting natural planktonic bacteria and understanding the structure of planktonic bacterial communities. Scientia Marina, v. 64, n. 2, p. 197-224, 2000.

LEGENDRE, L.; COURTIES, C.; TROUSSELLIER, M. Flow cytometry in oceanography 1989--1999: environmental challenges and research trends. Cytometry, v. 44, n. 3, p. 164-72, 2001.

MARIE, D. et al. Enumeration and cell cycle analysis of natural populations of marine picoplankton by flow cytometry using the nucleic acid stain SYBR Green I. Applied and Environmental Microbiology, v. 63, n. I, p. 186-193, 1997. 
MARIE, D.; SIMON, N.; VAULOT, D. Phytoplankton Cell Counting by Flow Cytometry. In: Algal culturing techniques. [s.l: s.n.]. p. 253-556.

MORÁN, X. A. G. et al. Assessing the relevance of nucleic acid content as an indicator of marine bacterial activity. Aquatic Microbial Ecology, v. 46, p. 141152, 2007.

OLSON, R. J.; CHISHOLM, S. W.; ZETTLER, E. R. Pigments, size, and distribution of Synechococcus in the North Atlantic and Pacific Oceans. Limnology and Oceanography, v. 35, n. I, p. 45-58, 1990.

OLSON, R. J.; VAULOT, D.; CHISHOLM, S. W. Marine phytoplankton distributions measured using shipboard flow cytometry. Deep Sea Research Part A. Oceanographic Research Papers, v. 32, n. 10, p. 1273-1280, 1985.

ORTEGA-RETUERTA, E. et al. Exploring the relationship between active bacterioplankton and phytoplankton in the Southern Ocean. Aquatic Microbial Ecology, v. 52, p. 99-106, 10 jul. 2008.

PARTENSKY, F.; BLANCHOT, J.; VAULOT, D. Differential distribution and ecology of Prochlorococcus and Synechococcus in oceanic waters: a review. Bulletin de l'Institut océanographique, 1999.

PARTENSKY, F.; HESS, W. R.; VAULOT, D. Prochlorococcus, a marine photosynthetic prokaryote of global significance. Microbiology and molecular biology reviews : MMBR, v. 63, n. 1, p. 106-127, 1999.

SCANLAN, D. J. et al. Ecological genomics of marine picocyanobacteria. Microbiology and molecular biology reviews : MMBR, v. 73, n. 2, p. 249299, 2009.

SHAPIRO, H. M. Practical flow cytometry, 3rd Edition, by Howard M. Shapiro, M.D., Wiley-Liss, Inc., New York, 1995, 542 pages. 4th Ed. ed. Hoboken, New Jersey: [s.n.].

SIMON, N. et al. Characterization of Oceanic Photosynthetic Picoeukaryotes By Flow-Cytometry. Journal of Phycology, v. 30, n. 6, p. 922-935, 1994. 
SOSIK, H. M.; CHISHOLM, S. W.; OLSON, R. J. Chlorophyll fluorescence from single cells: Interpretation of flow cytometric signalsLimnology and Oceanography, 1989.

TRASK, B. J.; VAN DEN ENGH, G. J.; ELGERSHUIZEN, J. H. Analysis of phytoplankton by flow cytometry. Cytometry, v. 2, n. 4, p. 258-264, 1982.

VAN WAMBEKE, F. et al. Vertical and longitudinal gradients in HNA-LNA cell abundances and cytometric characteristics in the Mediterranean Sea. Biogeosciences, v. 8, n. 7, p. 1853-1863, 13 jul. 2011.

VAULOT, D. et al. The diversity of small eukaryotic phytoplankton $(<$ or $=3$ microm) in marine ecosystems. FEMS microbiology reviews, v. 32, n. 5, p. 795-820, ago. 2008.

VAULOT, D.; MARIE, D. Die1 variability of photosynthetic picoplankton in the equatorial Pacific. Journal of Geophysical Research, v. 104, n. C2, p. 32973310, 1999.

VIVES-REGO, J.; LEBARON, P.; CARON, G. N. Current and future applications of $£$ ow cytometry in aquatic microbiology. FEMS microbiology reviews, v. 24 , p. 429-448, 2000.

WANG, Y. et al. Past, present and future applications of flow cytometry in aquatic microbiology. Trends in Biotechnology, v. 28, n. 8, p. 416-424, 2010.

ZUBKOV, M. V et al. Picoplanktonic community structure on an Atlantic transect from 50 degree $N$ to 50 degree S. Deep-Sea Research (Part I, Oceanographic Research Papers), v. 45, n. 8, p. 1339-1355, 1998a.

ZUBKOV, M. V et al. Picoplanktonic community structure on an Atlantic transect from $50^{\circ} \mathrm{N}$ to $50^{\circ} \mathrm{S}$. Deep Sea Research Part I: Oceanographic Research Papers, v. 45, n. 8, p. 1339-1355, ago. 1998b. 